\title{
Avaliação do papel de proibitina no desenvolvimento de resistência à cisplatina em linhagens de melanoma
}

\author{
humano
}

Dissertação apresentada à Faculdade de Medicina da Universidade de São Paulo para obtenção do título de Mestre em Ciências

Área de concentração: Oncologia

Orientador: Dr. Roger Chammas

São Paulo 2008 
"Quando analisamos os indivíduos pertencentes à mesma variedade ou subvariedade de nossos vegetais e animais cultivados e criados desde os tempos mais antigos, observamos que eles geralmente diferem muito mais entre si do que entre os indivíduos de qualquer espécie ou variedade em estado natural"

Charles Darwin - A Origem das Espécies 


\section{AGRADECIMENTOS}

À minha família, pelo apoio dado durante todos esses anos.

À minha namorada, Renata, com quem eu espero estar junto para sempre.

Ao meu orientador, Dr. Roger Chammas, pela oportunidade, amizade e apoio necessário para a realização deste projeto, além de me ensinar muito sobre biologia.

À Dra. Maria Mitzi Brentani, pelo apoio dado.

Ao departamento de Radiologia e Disciplina de Oncologia da Faculdade de Medicina da USP, onde este projeto foi realizado.

Ao Grupo de Adesão Celular e Câncer, incluindo os que não fazem mais parte dele, pelos momentos agradáveis que eu passei por lá.

À Andréia Hanada Otake, que me "iniciou” no laboratório.

À Luciana Nogueira de Sousa Andrade pelo fornecimento dos anticorpos contra $\gamma$ H2AX e RAD51, além, é claro, da amizade.

À Débora Casolari pela ajuda com os ensaios de siRNA.

A todo pessoal do LIM24, que de alguma forma contribuíram para este trabalho. 
À Ana Lúcia Garippo pela ajuda com a microscopia confocal

Aos funcionários, Maria José, Ivonete, Elizângela, Rose, Cristina, Jair e Willame, sem os quais este projeto não seria possível ser realizado.

À FAPESP e ao CNPq, pelo apoio financeiro. 


\section{ÍNDICE}

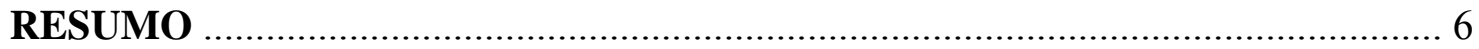

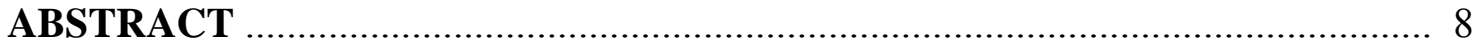

LISTA DE ABREVIATURAS ………………………………………... 10

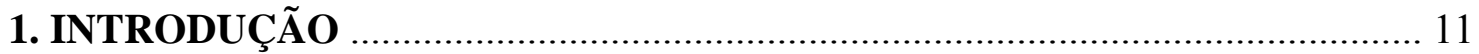

1.1 - A célula Cancerosa e o Processo de evasão de morte celular ................................. 11

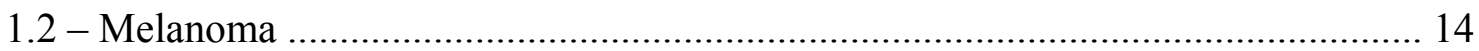

1.3 - Cisplatina e a Quimiorresistência .......................................................... 16

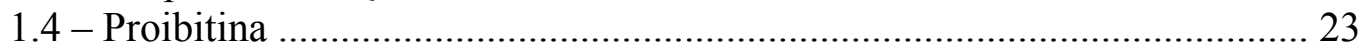

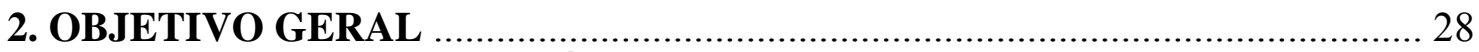

2.1 -OBJETIVOS ESPECÍFICOS........................................................... 28

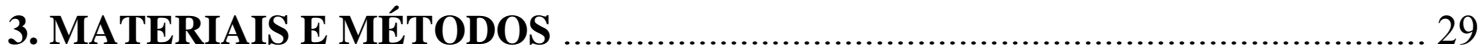

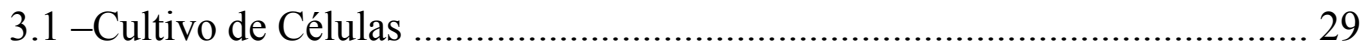

3.2 -Ensaio de Morte Celular ......................................................................... 29

3.3 -Análise do Ensaio de Morte Celular .......................................................... 30

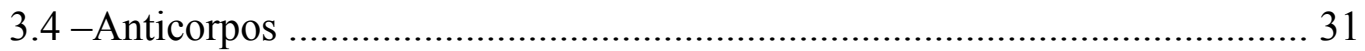

3.5 -Extração de Proteínas ................................................................................ 32

3.6 -Dosagem Protéica ...................................................................................... 33

3.7 -Gel de Poliacrilamida e Western Blot ......................................................... 33

3.8 -Microscopia Confocal ........................................................................ 34

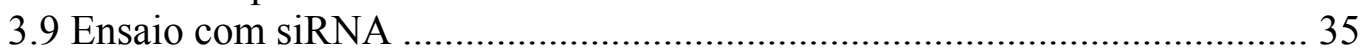

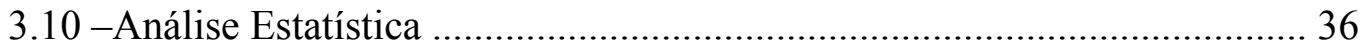

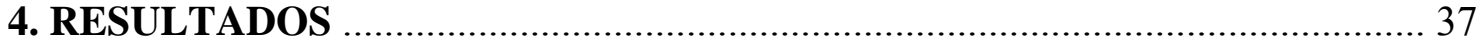

4.1 -Ensaio de Morte Celular (FACS) ……………………............................... 37

4.2 - Análise da expressão de proibitina após tratamento com cisplatina ......... 45

4.3 -Determinação da localização celular de proibitina ...................................... 46

4.4 - Avaliação da subexpressão de proibitina ................................................... 62

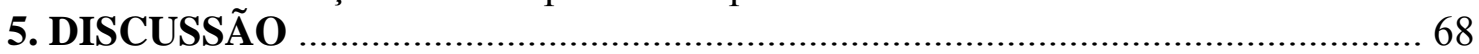

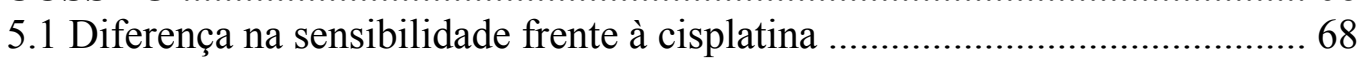

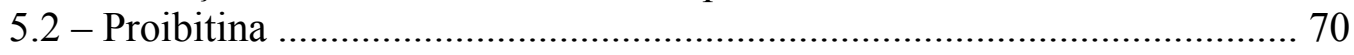

5.2.1 Subexpressão de Proibitina ................................................................. 70

5.2.2 Localização Subcelular de Proibitina .......................................................... 74

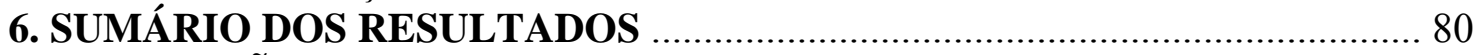

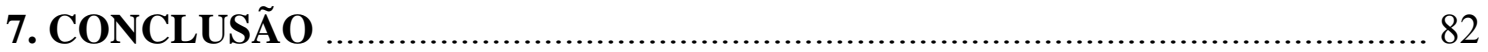

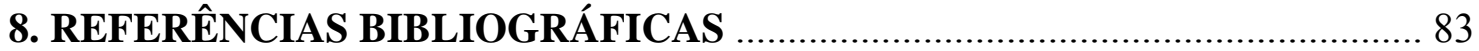

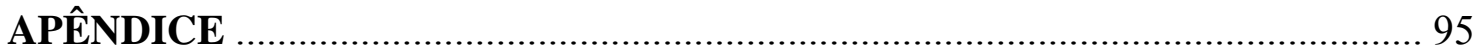




\section{RESUMO}

A incidência de melanomas tem crescido mundialmente. Apesar de representar um potencial problema de saúde pública pela sua incidência crescente, melanomas ainda se apresentam como tumores de difícil tratamento, especialmente quando diagnosticados em estadios avançados. A taxa de resposta a quimioterapia não ultrapassa $30 \%$ de resposta clínica objetiva nestes casos. As bases moleculares da quimiorresistência não são ainda completamente esclarecidas e seu conhecimento será útil para o delineamento de estratégias de quimiossensibilização. Em estudos anteriores, observamos que o tratamento de linhagem de células de melanoma metastático humano com o quimioterápico cisplatina induz o acúmulo de proibitina nas células sobreviventes. Proibitina é uma molécula expressa ubiquamente na maioria das células. Há evidências de que a forma nuclear esteja envolvida com o processo de morte celular e inibição de E2F1 enquanto a forma citoplasmática parece atuar como chaperona mitocondrial, garantindo sua homeostasia. O objetivo deste projeto foi avaliar a compartimentalização subcelular e a expressão de proibitina, após tratamento com 25 $\mu \mathrm{M}$ de cisplatina por 24 horas em diferentes linhagens de melanoma metastático humano; e, o efeito de sua subexpressão, usando-se small interference (si) RNA. Nós mostramos que nas linhagens de melanoma humano LB373Mel, SKMel 37 e Mel 85, a proibitina foi encontrada predominantemente no citoplasma, associada, pelo menos em parte, com a mitocôndria. Após tratamento com cisplatina, uma porção da proibitina também foi encontrada no núcleo, como pode ser detectado utilizando-se anticorpo monoclonal (clone II-14-1). Experimentos de knockdown de proibitina por siRNA obtiveram sucesso em duas de três linhagens. Nessas duas linhagens (LB373Mel e Mel 85), o bloqueio do acúmulo de proibitina após tratamento com cisplatina levou à 
quimiossensibilização. A quimiossensibilização à cisplatina não foi observada na linhagem SKMel 37, que foi capaz de acumular proibitina mesmo quando tratada com siRNA específico para proibitina. A conclusão deste projeto é que a expressão de proibitina é parte da resposta celular que leva a sobrevivência de células de melanoma expostas à cisplatina. 


\section{ABSTRACT}

The incidence of melanomas has grown world-wide. Besides representing a potential problem of public health for its increasing incidence, melanomas are tumors of difficult treatment, especially when diagnosed in advanced phases. The clinical objective response rate does not exceed $30 \%$ in these cases. The molecular bases of chemoresistance are not completely clarified and their understanding will be useful for the delineation of chemosensitization strategies. In previous studies, we observed that the treatment of a human metastatic melanoma cell line with the chemotherapeutic agent cisplatin induced the accumulation of prohibitin in the surviving cells. Prohibitin is ubiquitously expressed molecule in most cells. There is evidence that the nuclear form is involved with the process of cell death and inhibition of E2F1, while the cytoplasmic form seems to act as mitochondrial chaperone, guaranteeing its homeostasis. The aim of this project was to evaluate the subcellular compartmentalization and protein expression profile of prohibitin, after treatment with $25 \mu \mathrm{M}$ of cisplatin for 24 hours in different human metastatic melanoma cell line, and the effect of its underexpression, using siRNA. We showed that, in human melanoma cell lines, LB373Mel, SKMel 37 and Mel 85, prohibitin was found predominantly in the cytoplasm, associated at least in part with the mitochondria. Upon cisplatin treatment, a fraction of prohibitin was also found in the nucleus, as detected by using a monoclonal antibody (clone II-14-10). Knockdown experiments were successful in two out of three cell lines. In these two cell lines (LB373Mel and Mel 85) blockage of the accumulation of prohibitin upon cisplatin treatment led to chemosensitization. Chemosensitization to cisplatin was not observed for SKMel 37 cells, which accumulated prohibitin even when treated with prohibitin specific siRNA oligonucleotides. Altogether, we concluded that expression of prohibitin 
is part of the cellular response that leads to cell survival in melanoma cells exposed to cisplatin. 


\section{LISTA DE ABREVIATURAS}

APS - Persulfato de Amônio

BSA - do inglês, Bovinum Serum Albumin

DAPI - 4',6-diamidino-2-phenylindole

DTT - Dietiltrietol

EDTA - Acido Etileno Diamino Tetraacético

HR - do inglês, Homologous Recombination

NHEJ - do inglês, Non Homologous End-Joining

O.N. - Overnight

PBS - Tampão Fosfato Salina

PHB - Proibitina

PHB2 - Proibitona

PMSF - Fenilmetilsulfonilfluoreto

PVDF - do inglês, Hydrophobic Polyvinylidene Difluoride

RGP - do inglês, Radial Growth Phase

ROS - do inglês, Reactive Oxigen Species

SDS - Dodecil Sulfato de Sódio

SDS-PAGE - do inglês, SDS -Polycrylamide Gel Electroforesis

SFB - Soro Fetal Bovino

siRNA - Short Interference Ribonucleic Acid

TEMED - N,N,N,N Tetra Metiletilenodiamina

VGP - do inglês, Vertical Growth Phase 


\section{INTRODUÇÃO}

\subsection{A célula cancerosa e o processo de evasão a morte celular}

Cânceres são doenças complexas, caracterizadas por alterações genômicas que levam a (1) ativação de vias associadas a vários genes que controlam positivamente a proliferação e sobrevivência celular, como os oncogenes; e/ou, (2) a inativação de genes que controlam negativamente estes processos, como os genes supressores de tumor; ou ainda, disfunção de genes que controlam a estabilidade genômica (genes de reparo de DNA). Sua complexidade é entendida em termos de alguns princípios onde alterações genéticas, que levam à alteração na função ou padrão de expressão do produto dos genes, ativando ou inativando vias de controle da homeostasia celular se somam a alterações epigenéticas, que levam a alterações no padrão de expressão de outros genes, levando a perturbações da fisiologia celular. Segundo Hanahan e Weinberg, que sistematizaram as principais classes destas alterações, seis são as alterações funcionais que caracterizam a transformação maligna completa, isto é, o desenvolvimento do câncer (Hanahan and Weinberg, 2000). São elas: auto-suficiência em fatores de crescimento (Skobe and Fusenig, 1998); insensibilidade a inibidores de crescimento (Weinberg, 1995); potencial infinito de replicação (Hayflick, 1997); (Bryan and Cech, 1999); angiogênese (Hanahan and Folkman, 1996); (Varner and Cheresh, 1996); capacidade de invadir tecidos (Sporn, 1996); (Werb, 1997); e evasão de apoptose (Harris, 1996); (Ashkenazi and Dixit, 1999).

A evasão do processo apoptótico é uma das alterações mais importantes necessárias para a sobrevivência de uma célula tumoral. Esta característica garante à célula cancerosa a capacidade de proliferação sustentada em diferentes microambientes 
teciduais. Células normais desalojadas de seus tecidos de origem tendem a morrer, por ativação de um processo que vem sendo chamado de anoikis (do grego, sem casa ou desalojado). As células cancerosas resistem à morte por desalojamento. De nada adiantaria o crescimento descontrolado de células tumorigênicas, a sua capacidade de criar novos vasos, sua auto suficiência em crescer, se elas não sobrevivessem ao desalojamento tecidual (anoikis). Esta característica da célula cancerosa se deve à inativação de vias que desencadeiam o processo de apoptose. Sua conseqüência clínica é a progressiva resistência à indução de morte por diferentes agentes como os agentes utilizados em quimio- e radioterapia.

De maneira simplificada, sinais que levam à morte celular podem ser de natureza extracelular, como ocorre por exemplo na ativação de receptores como FASL, pela interação com FAS (Ashkenazi and Dixit, 1999). Esses sinais levam a ativação de vias controladas por caspases, cisteíno-aspártico proteases cuja ativação leva a um processo de proteólise limitada que converge para alterações mitocondriais associadas à liberação de fatores pró-apoptóticos desta organela, como o citocromo $\mathrm{C}$, que leva à ativação de outras caspases ditas executoras, e AIF (apoptosis inducing factor) (Green and Reed, 1998); (Thornberry and Lazebnik, 1998), levando às alterações celulares características de apoptose.

A liberação de citocromo $\mathrm{C}$ no citoplasma é regulada por membros da família Bcl-2. Esta família apresenta como membros, por exemplo, as proteínas pró-apoptóticas (Bax, Bak, Bid e Bim) e as proteínas anti-apopoptóticas (BCL-2, Bcl-XL, Bcl-W). O produto do gene supressor de tumor TP53 atua como um regulador da via de apoptose, por controlar a transcrição de Bax. Esta atividade depende da fosforilação da proteína p53, por quinases ativadas pelo reconhecimento de danos extensos no DNA. Este exemplo mostra a interconvergência de vias que estão associadas ao desenvolvimento 
do câncer e principalmente à progressiva resistência da célula tumoral a indutores de morte celular.

Diferentes alterações moleculares levam à quimio- ou rádiorresistência dos tumores. As mais comuns são mutações envolvendo o gene da proteína supressora de tumor p53. Mutações em TP53 são encontradas em mais de 50\% dos tumores humanos (Harris, 1996); hoje são descritas mais de 27.000 diferentes mutações neste gene, segundo a UMD TP53 Mutation Database, sendo a maioria delas encontrada na região codificadora dos éxons 5-8, que correspondem aos domínios de ligação de p53 ao DNA. Contudo há tumores onde mutações em TP53 são infreqüentes. É o caso dos melanomas, tumores que se desenvolvem a partir de melanócitos. Estima-se que menos de $10 \%$ dos melanomas humanos apresentem mutações em TP53. Ao mesmo tempo, os melanomas estão entre os tumores mais resistentes a diferentes tipos de tratamento quimioterápico. As taxas de resposta destes tumores quando em estadio avançado não ultrapassam a faixa dos $15-30 \%$ de resposta clínica objetiva. Nosso grupo vem desenvolvendo diferentes estudos que visam compreender a progressão do melanoma e as bases moleculares de sua possível quimiorresistência. A abordagem seguida inclui a avaliação proteômica de sistemas de progressão tumoral em linhagens celulares. Numa primeira abordagem, usando um sistema de melanoma murino, foi possível identificar um conjunto de proteínas cuja expressão está alterada no melanoma murino. Observamos um acúmulo muito significativo de uma molécula chamada nucleofosmina, que está envolvida na repressão funcional de p53 (de Souza et al. 2006). Este achado parece comum em melanomas humanos, usando-se uma abordagem semelhante à nossa (Bernard et al. 2003). Assim, apesar de não apresentarem mutações freqüentes em TP53, há evidências que sugerem que as vias de p53 estão reprimidas em melanomas, o que poderia justificar a insensibilidade deste tumor contra diferentes quimioterápicos. 
A insensibilidade do tumor contra drogas quimioterápicas se inicia pela seleção de populações resistentes dentro da massa tumoral. Dentro de uma população de células tumorais, o quimioterápico pode funcionar como um fator de seleção, onde algumas células, que são capazes de sobreviver ao agravo gerado pela droga, acabam sobrevivendo e proliferam. Isso torna o tumor progressivamente mais agressivo e insensível ao tratamento. Essa insensibilidade, em última análise, é responsável pelas mortes causadas por um câncer.

\subsection{Melanoma}

Como mencionado acima, o melanoma é um tipo de câncer de pele originado nos melanócitos com predominância em adultos brancos e sua incidência tem crescido mundialmente. Apesar de sua baixa incidência, representa apenas $4 \%$ de todos os tipos de câncer de pele, possui alta letalidade. Além de representar um potencial problema de saúde pública pela sua incidência crescente, melanomas ainda se apresentam como tumores de difícil tratamento, especialmente quando diagnosticados em estadios avançados, apresentando taxa de resposta a quimioterapia que não ultrapassa $30 \%$ de resposta clínica objetiva

Os principais fatores de risco ao desenvolvimento do melanoma são: a sensibilidade ao sol (queimadura pelo sol e não bronzeamento), a pele clara, a exposição excessiva ao sol, a história prévia de câncer de pele, história familiar de melanoma, nevo congênito (pinta escura), maturidade (após 15 anos de idade a propensão para este tipo de câncer aumenta), Xeroderma Pigmentoso (doença congênita que se caracteriza pela intolerância total da pele ao sol, com queimaduras externas, lesões crônicas e 
tumores múltiplos) e nevo displásico (lesões escuras da pele com alterações celulares pré-cancerosas) (INCA - Instituto nacional do Câncer).

Melanomas podem ser classificados de acordo com sua localização anatômica e padrão de crescimento em melanomas de crescimento radial (RGP), onde não há comprometimento da lâmina basal da epiderme ou vertical (VGP), onde há o comprometimento da lâmina basal com invasão da derme (Chudnovsky et al. 2005).

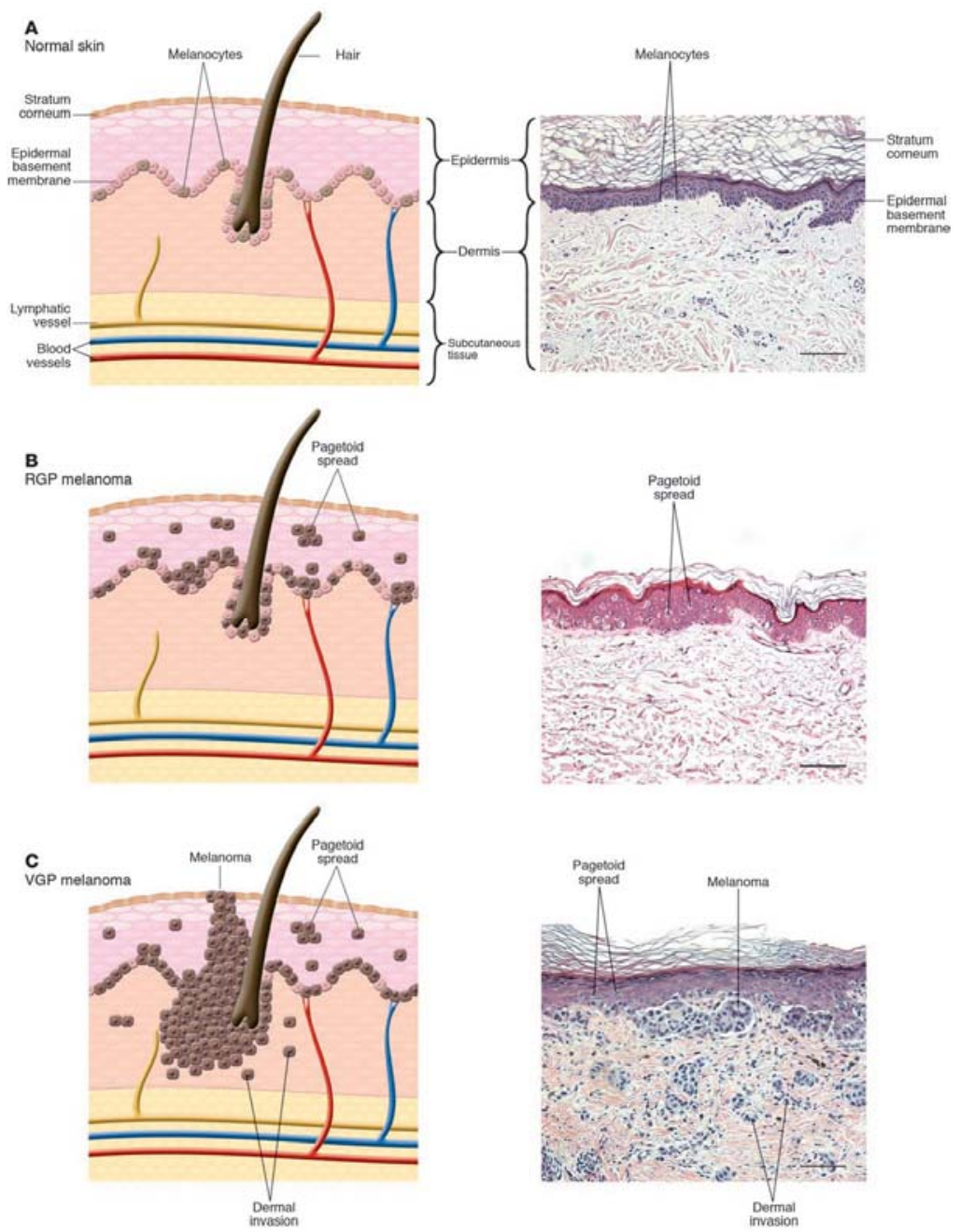

Figura 1. Fases histológicas da transformação melanocítica. (A) Pele normal. (B) Melanoma de crescimento radial (RGP). (C) Melanoma de crescimento vertical (VGP). Adaptado de Chudnovsky et al, J Clin Invest. 2005 Apr;115(4):813-24. 
Biologicamente, o desenvolvimento do melanoma pode ser resumido através de modificações genéticas ou epigenéticas que levam à perda de expressão de proteínas relacionadas ao controle do ciclo celular como p16 ${ }^{\mathrm{INK} 4 \mathrm{a}}, \mathrm{p} 14^{\mathrm{ARF}}, \mathrm{CDK} 4$ e CDK6, pRB e p53 (Chin, 2003); (Sharpless et al. 2003); a translocação de $\beta$-Catenina para o núcleo, com a ativação de genes relacionados com a transição epitélio-mesenquimal, além de diminuir a adesão mediada por caderina (Lee et al. 2006); o aumento na atividade da via MAPK e AKT, que são necessárias para o desenvolvimento de um melanoma de crescimento radial e vertical, respectivamente (Govindarajan et al. 2003); (Govindarajan et al. 2007), além de estarem relacionadas a vias de sobrevivência (Govindarajan et al. 2007).

\subsection{Cisplatina e a Quimiorresistência}

Tem-se postulado que o conhecimento de mecanismos que levam à quimiorresistência seja fundamental para o desenho de estratégias que possam aumentar a eficiência da quimioterapia. No caso do melanoma, os tratamentos quimioterápicos considerados padrão são os que utilizam a dacarbazina (DTIC) como agente. Ainda, protocolos clínicos propõem o uso de monoterapia com cisplatina ou ainda poliquimioterapia incluindo as drogas acima e o uso de vinblastina ou outros alcalóides da vinca, entre os esquemas de melhor resultado. Cada droga atua de maneira particular, mas elas acabam por ativar uma via apoptótica, dependente ou não da proteína reguladora de tumor p53, que é importante na ativação do processo apoptótico.

A cisplatina (cis-diaminodicloroplatina II) é um dos agentes antitumorais mais potentes conhecidos, atuando em vários tipos de tumores, como câncer de ovário, testículo e cabeça e pescoço (Siddik, 2003). A cisplatina sofre uma modificação 
estrutural após entrar na célula para poder exercer sua função biológica. Ao entrar em um ambiente intracelular com pouco cloreto, a cisplatina é hidratada formando um composto carregado positivamente que pode reagir com espécies nucleofílicas (Cullen et al. 2007).

Um dos alvos da cisplatina pode ser o DNA nuclear, o que a caracteriza como um agente indutor de dano no DNA (Cullen et al. 2007). Sua citotoxicidade ocorre pela interação dos sítios N7 de bases púricas, formando interações do tipo DNA-proteínas ou do tipo DNA-DNA, o que leva a formação de um aduto na mesma fita ou entre as fitas complementares do DNA (Eastman, 1987). Entretanto, o aduto formando pela ligação da cisplatina entre fitas complementares parece ser o principal responsável pela sua ação citotóxica (Pinto and Lippard, 1985).

Embora os adutos de DNA gerados pela ação da cisplatina afetem a replicação do DNA, não há uma correlação entre a inibição da síntese de DNA e citotoxicidade (Sorenson and Eastman, 1988). A citotoxicidade gerada pela cisplatina é iniciada através do reconhecimento do dano no DNA, através de moléculas responsáveis pelo seu reparo (Bellon et al. 1991), que podem levar a indução de morte celular ou a parada de ciclo celular na fase G2/M (Shi et al. 1994); (Shapiro and Harper, 1999). Há, ainda, uma correlação direta entre a quantidade de adutos formados e a citotoxicidade causada pela cisplatina (Donahue et al. 1990). Entre as moléculas envolvidas no reparo de DNA, estão: hMSH2 ou hMutS $\alpha$ - componentes do "mismatch repair complex" (MMR) (Donahue et al. 1990); HMG1 e HMG2; o fator de ligação "upstream" do transcrito da RNA polimerase I humana (hUBF); a proteína de ligação do fator transcricional TATA (TBP) (Donahue et al. 1990); (Fink et al. 1998); (Chaney and Vaisman, 1999).

O principal mecanismo de reparo dos adutos de DNA gerados pela ação da cisplatina é o mecanismo de reparo por excisão de nucleotídeos (NER) (Altaha et al. 
2004). Este mecanismo é muito conservado durante a evolução e é responsável por reparar lesões que levam a alteração da estrutura helicoidal do DNA (Escargueil et al. 2008). O reparo por excisão de nucleotídeos pode ser dividido em: reparo global do genoma (GGR), responsável pelo reparo de regiões não codificantes do DNA e por fitas não transcritas de genes expressos; e pelo reparo de fita em genes expressos, em que há transcrição (TCR) (Escargueil et al. 2008). O que diferencia esses mecanismos é a maneira como a lesão do DNA é reconhecida, sendo XPC uma molécula importante para o reparo global de DNA (Escargueil et al. 2008).

Os adutos gerados pela cisplatina podem também induzir quebra de dupla fita de DNA, de uma maneira dose-dependente (Nowosielska and Marinus, 2005). Seu reparo ocorre pelos mecanismos de recombinação homóloga (HR) e pela junção não-homóloga (NHEJ) (Pastwa and Blasiak, 2003), onde a fosforilação da histona $\gamma$-H2AX é um passo importante na iniciação desses tipos de reparo (Shrivastav et al. 2008).

Outro mecanismo de reparo que pode corrigir a ação citotóxica dos adutos gerados pela cisplatina é o mecanismo de reparo da Anemia Fanconi, onde um complexo protéico é necessário para a ubiquitinação de FANCD2, que inicia o processo de reparo (Jacquemont and Taniguchi, 2007). Uma proteína que participa desse processo é a recombinase RAD51 (Klein, 2008). Sua superexpressão pode contribuir para a quimiorresistência de tumores (Hannay et al. 2007).

Após ser reconhecida pelos mecanismos de reparo, a lesão no DNA pode ativar outros efetores que não levam, necessariamente, à morte celular. Uma dessas vias pode ativar checkpoints de ciclo celular, levando a uma parada transitória na fase S, seguido por uma parada permanente em G2/M (Shi et al. 1994); (Shapiro and Harper, 1999). Outras proteínas como ERK, JNK e p38 também são ativadas após a exposição de células tumorais a cisplatina (Persons et al. 2000). 
A ação da cisplatina ativa também vias dependentes (Segal-Bendirdjian et al. 1998) ou não (Hawkins et al. 1996) de p53 que levam ao processo de apoptose. Uma dessas vias é a indução de Bax e diminuição de Bcl-2 induzidas pela cisplatina (Del Bello et al. 2001) ou pela indução de apoptose dependente de p73, através da ativação de c-Abl e de MMR (Kharbanda et al. 2000).

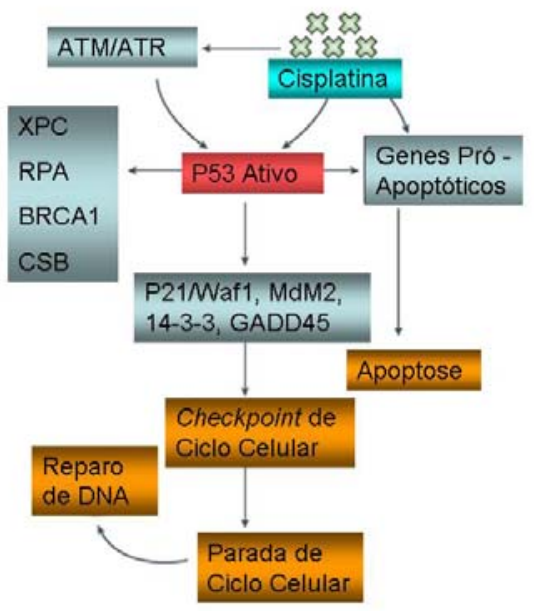

Figura 2. Mecanismos de ação da cisplatina. Adaptado de Wang e Lippard, Nat Rev Drug Discov. 2005 Apr;4(4):307-20.

Outra linha de evidência sugere que a mitocôndria seja um alvo critico da cisplatina (Cullen et al. 2007). O DNA mitocondrial é particularmente sensível a cisplatina por não ser capaz de reparar eficientemente seu DNA através do reparo por excisão de nucleotídeos (NER) (Preston et al. 2001).

A ação da cisplatina pode levar a uma disfunção da mitocôndria através da produção de espécies reativas de oxigênio (ROS) (Martins et al. 2008). Esse processo leva a ativação de vias de apoptose através de p53 (Li et al. 1999) e/ou pela liberação de citocromo c (Hoye et al. 2008), mas também pode levar à migração e ao crescimento celular (Ushio-Fukai, 2006), a um enovelamento errado de proteínas, que pode ser

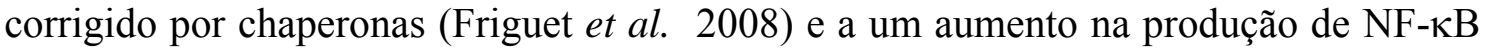


que leva à produção de VEGF (Govindarajan et al. 2007), SIRT1 (uma histona deacetilase que inibe a atividade de p53) (Luo et al. 2001); (Vaziri et al. 2001) e rictor (uma subunidade de mTOR relativamente insensível à rapamicina) (Sarbassov et al. 2004).

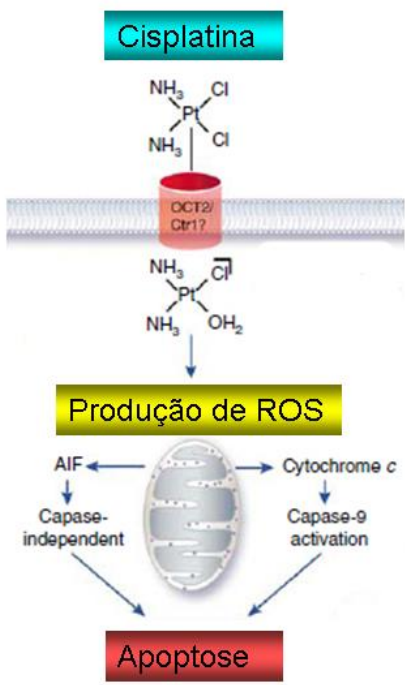

Figura 3. Ação da cisplatina na mitocôndria. Adaptado de Pabla e Dong, Kidney Int. 2008 May;73(9):994-1007. Epub 2008 Feb 13.

A resistência a cisplatina ocorre quando há falha na capacidade da célula entrar em apoptose. Esse processo pode ocorrer pela exposição crônica ao quimioterápico ou por uma capacidade intrínseca da célula tumoral. De maneira geral, os mecanismos de resistência impedem o contato da cisplatina com o seu alvo ou evitam a sinalização próapoptótica decorrente do efeito da cisplatina. Apesar de apenas um único mecanismo de resistência poder ocorrer em células tumorais (Kelland et al. 1992), o mais comum é que uma combinação de vários mecanismos aconteçam ao mesmo tempo em prol da sobrevivência celular(Richon et al. 1987). 
Entre os mecanismos mais importantes estão:

1. Redução do acúmulo intracelular de cisplatina, por diminuição de sua captação (Kelland, 2000), pelo aumento da extrusão da droga, via receptor MRP2 (Kool et al. 1997) ou por uma combinação desses dois mecanismos;

2. Inativação de cisplatina por moléculas nucleofílicas como as glutationas (GSH), que tem sua expressão aumentada após exposição crônica ao quimioterápico (Kelland, 1993);

3. Aumento da capacidade de reparo de DNA, principalmente pelo reparo de excisão de nucleotídeos (Furuta et al. 2002);

4. Aumento da expressão de Bcl-2 (Isonishi et al. 2001).

\section{Figura}

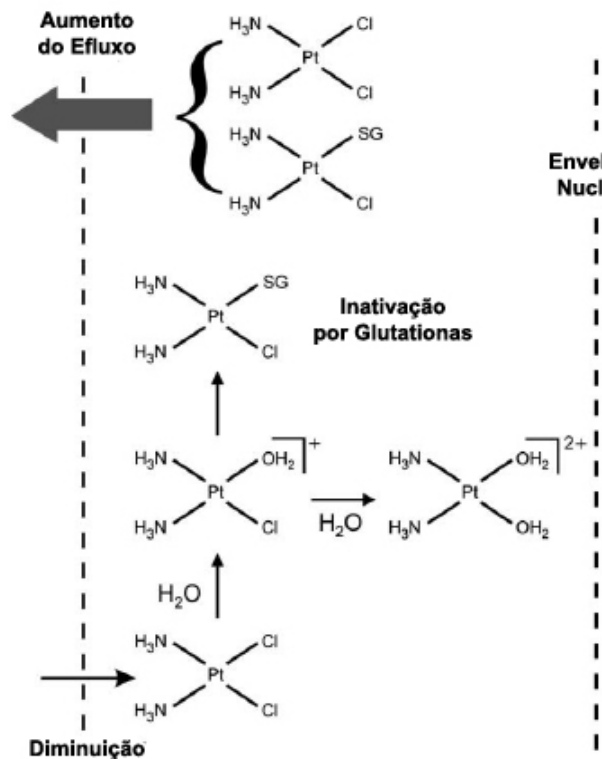

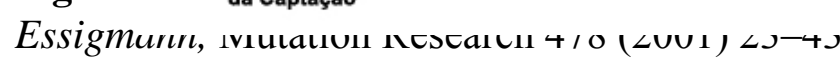

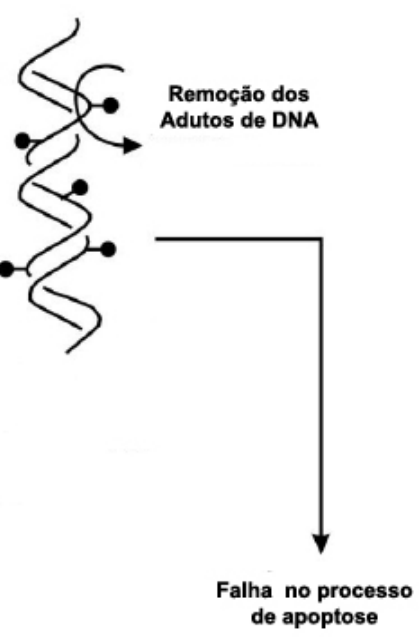

Em estudo colaborativo envolvendo nosso grupo, identificaram-se algumas proteínas acumuladas ao longo do processo de aquisição de resistência de uma linhagem de melanoma (LB373Mel) ao tratamento com cisplatina. Entre 
as proteínas acumuladas, encontra-se a molécula de proibitina, alvo da presente dissertação (Fig. 5).

\section{(a) Tempo de Exposição à Cisplatina}

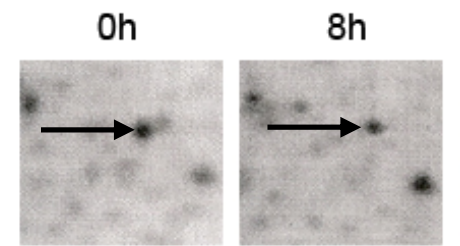

$16 \mathrm{~h}$

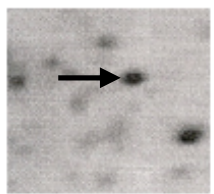

329

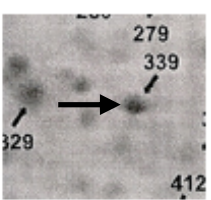

(b)

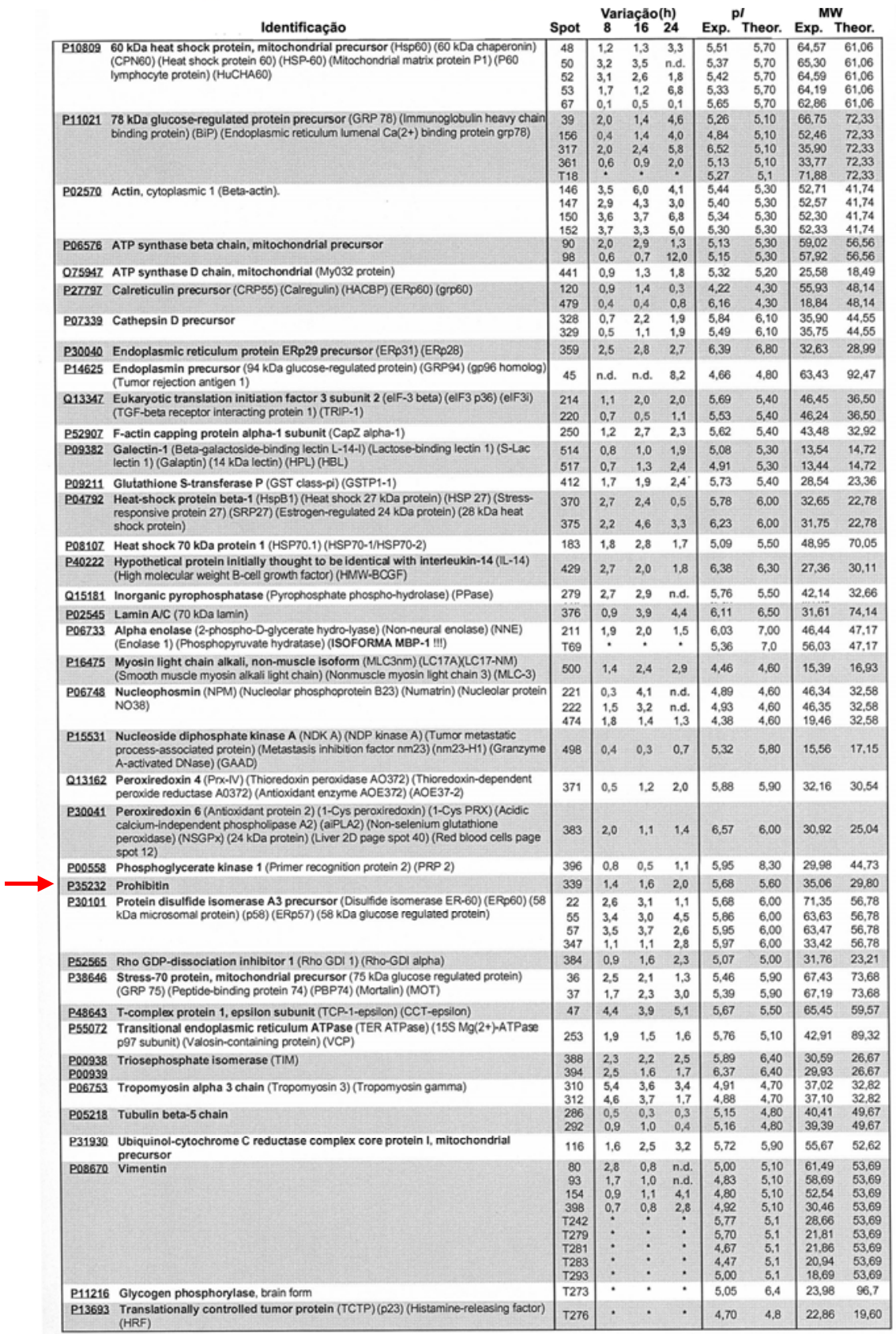

Figura 5. Proteoma da linhagem LB373Mel após tratamento com $25 \mu \mathrm{M}$ de cisplatina por 24 horas. (a) Aumento da expressão de proibitina, indicada pela seta, durante exposição à cisplatina. (b) Tabela representando a variação de expressão de diversas proteínas após tratamento com cisplatina. PHB está indicada pela seta vermelha. Adaptado de Godoy et al. 


\subsection{Proibitina}

A proibitina ( $\mathrm{PHB}$, ou proibitina 1) é uma proteína ubiquamente expressa, encontrada principalmente na mitocôndria, no núcleo e na membrana plasmática. Possui massa molecular de 30-32 kDa, apresentando similaridade com uma proteína chamada proibitona (PHB2), de massa molecular de $37 \mathrm{kDa}$. PHB e PHB2 podem formar um complexo de alto peso molecular, identificado na mitocôndria e na membrana plasmática (Nijtmans et al. 2000); (Sharma and Qadri, 2004). Sua estrutura é altamente conservada, sendo a proibitina de rato idêntica a de camundongo, diferindo em apenas um único aminoácido da proibitina humana. O gene humano da proibitina 1 localiza-se no cromossomo 17 (17q21) (Sato et al. 1992) enquanto que o gene humano da proibitina 2 localiza-se no cromossomo 12 (12p13) (Terashima et al. 1994). O knockout do gene de PHB leva à perda de expressão sustentada da proteína PHB2 e vice-versa (Berger and Yaffe, 1998).

A proibitina possui um domínio do tipo SPFH (Stomatin, Prohibitin, Flotillin, HflK/C), na sua porção amino-terminal, possuindo um domínio transmembrânico. Na sua porção carboxi-terminal, há uma repetição de EA (Glutamato e Alanina), importante para a formação de oligômeros (Langhorst et al. 2005). Esse domínio permite que a proibitina associe-se a lipídios, além de ancorar-se à membrana plasmática (Sharma et al. 2004) para formar arcabouços, onde pode atuar através de vias de sinalização com o citoesqueleto (Liu et al. 2005). Arcabouços estruturais formados por proteínas com domínio SPFH podem, por um lado, formar plataformas estáveis para diversas funções biológicas e por outro lado, podem funcionar como unidades regulatórias dinâmicas, com implicação até na regulação da expressão gênica. 
Na mitocôndria, o complexo PHB-PHB2 localiza-se na membrana interna dessa organela. Esse complexo possui um papel na estabilização de proteínas mitocondriais associadas com a cadeia respiratória (Nijtmans et al. 2000), funcionando como uma chaperona mitocondrial. Sua falta está associada à deficiência da biogênese mitocondrial (Artal-Sanz et al. 2003). Mutantes de PHB, PHB2 e ambos têm a vida média mitocondrial diminuída, o que está associado a uma diminuição do potencial de membrana transmitocondrial. Mutações em genes envolvidos na manutenção da morfologia mitocondrial (Mmm1p) ou em genes envolvidos na manutenção do DNA mitocondrial (Mdm10p e Mdm12p) são letais, quando há falta de PHB ou PHB2 (Berger and Yaffe, 1998). Esse complexo, assim, é importante para estabilizar a produção de espécies reativas de oxigênio (ROS), podendo funcionar como um mecanismo de resistência contra drogas que atuam dessa forma, como a cisplatina.

A proibitina tem uma função importante na estabilidade mitocondrial. Ela esta envolvida na organização dos nucleóides mitocondriais, além de regular o número de cópias do DNA mitocondrial por estabilizar TFAM (Kasashima et al. 2008), um dos componentes do complexo nucleoprotéico mitocondrial. Esta estabilidade é importante para manter a capacidade angiogênica de células endoteliais, pois a falta de PHB leva ao aumento dos níveis de espécies reativas de oxigênio, o que por sua vez, aumenta os níveis de AKT e RAC1, levando a uma remodelação do citoesqueleto, diminuição da capacidade de formação de estruturas tubulares e de migração de células endoteliais (Schleicher et al. 2008).

No núcleo, a proibitina possui um papel muito importante como supressor de tumor. Ela pode inibir a proliferação celular através da repressão direta ou indireta da atividade transcricional de E2F e modular positivamente a atividade transcricional de p53 (Fusaro et al. 2003). Sua ação repressora direta da transcrição mediada por E2F se 
dá através de sua ligação de um sítio conservado, diferente de pRb. É necessário, também, o recrutamento de Brg-1/Brm (Wang et al. 2002). Apesar desse recrutamento se dar independentemente de $\mathrm{pRb}$, sua presença é necessária para a repressão de E2F (Wang et al. 2002). Por sua vez, sua ação indireta de repressão de E2F se dá pela estabilização pós-traducional de RNF2, que é capaz de inibir a expressão de p16. A proibitina, então, interfere na via p16-cdk4-Rb (Choi et al. 2008).

Em alguns modelos, a proibitina colocaliza-se com p53 induzindo sua atividade transcricional. No citoplasma, essa colocalização é mínima. Tratamento de linhagens de carcinoma de mama humano com camptotecina, um inibidor de topoisomerase (Rastogi et al. 2006), induz a saída de proibitina e p53 do núcleo e a migração de p53 para a mitocôndria. Sua colocalização após o tratamento se dá na região perinuclear, sugerindo uma atividade modulatória da apoptose por afetar a função de p53. Neste modelo especificamente, após algumas horas, a maior parte da proibitina se localiza no citoplasma sugerindo que sua saída do núcleo ocorre quando a célula progride em direção ao processo apoptótico (Fusaro et al. 2003). A saída de proibitina do núcleo depende de CRM-1 (Rastogi et al. 2006). Inibição da exportação nuclear de proibitina foi seguida de inibição de apoptose (Rastogi et al. 2006).

A via citoplasmática de sinalização Ras-Raf-MAPK-Erk depende de proibitina (Rajalingam et al. 2005). Essa via é muito conservada e importante em varias funções celulares, como proliferação, morte celular, migração, diferenciação e ativação de linfócitos T. Proibitina parece interferir levando à liberação de 14-3-3 por Raf, após a ativação deste por Ras. 14-3-3 é uma proteína capaz de formar arcabouços na membrana plasmática; e, na linhagem de carcinoma mamário humano MCF7 está envolvida em resistência a drogas (Liu et al. 2006). Várias linhagens de células tumorais, como HeLa, perdem a capacidade de migração quando há o silenciamento de 
PHB por siRNA. Esse efeito ocorre, possivelmente, pela relocalização de proteínas da junção aderente, como caderina e $\beta$-catenina para a membrana plasmática. A perda da capacidade migratória se daria, então, pela estabilização das junções aderentes (Rajalingam et al. 2005). Assim, PHB parece interferir nas vias de Ras e Wnt.

Ainda, a proibitina pode sofrer duas modificações estruturais: pode sofrer fosforilação por AKT (Han et al. 2008) ou então ser alquilada (Bouchon et al. 2007). A fosforilação por AKT é particularmente importante, pois a progressão de melanomas de crescimento radial em crescimento vertical, como mostrado na linhagem de melanoma com crescimento radial WM35, depende da superexpressão de AKT (Govindarajan et al. 2007) e seu bloqueio diminui a expressão de várias moléculas essenciais para a progressão do melanoma (Fried and Arbiser, 2008). A alquilação por cicloexilfenil-cloretil urea (CCEU) está associada com a parada de ciclo celular em G1, em linhagem de melanoma murino B16F10 (Bouchon et al. 2007).

Não se sabe se há diferenças na molécula de proibitina nos diversos tipos de tumor. Em algumas linhagens, pode-se observar sua localização nuclear como nas linhagens MCF-7 e T47D de câncer de mama (Rastogi et al. 2006). As alterações póstraducionais associadas a esta compartimentalização não estão esclarecidas.

Como mencionado acima, estudos de proteoma realizados em projeto colaborativo de nosso laboratório em melanoma LB373, revelaram que a proibitina acumula-se em células tratadas com cisplatina. Dados preliminares sugeriam que a localização de proibitina fosse predominantemente citoplasmática, independentemente do tratamento com cisplatina. Sua exclusão nuclear pode ocorrer devido a: (1) ineficiente translocação do citoplasma; ou (2) ativo mecanismo de exportação nuclear, graças a um mecanismo ainda não conhecido. Não foram relatados nenhum 
processamento ou alterações pós-traducionais que pudessem explicar esta compartimentalização diferencial. 


\section{OBJETIVO GERAL}

Avaliar se o acúmulo de proibitina frente ao agravo gerado pela cisplatina é parte do programa de indução de morte celular induzida por cisplatina ou é um mecanismo de resistência/proteção à morte celular

\subsection{OBJETIVOS ESPECÍFICOS}

1. Determinar a compartimentalização intracelular de proibitina em deferentes linhagens de melanoma humano;

2. Avaliar a distribuição intracelular de proibitina frente ao tratamento com cisplatina;

3. Bloquear a expressão de proibitina usando-se siRNA;

4. Avaliar o efeito da subexpressão de proibitina na resposta à cisplatina. 


\section{MATERIAIS E MÉTODOS}

Este projeto ( ${ }^{\circ}$ 1059/06) foi aprovado pela Comissão de Ética para Análise de Projetos de Pesquisa - CAPPesq da Diretoria Clínica do Hospital das Clínicas e da Faculdade de Medicina da Universidade de São Paulo (pág. 106).

\subsection{Cultivo de Células}

As seguintes linhagens de melanoma metastático humano foram utilizadas: SKMel 37 (Carey et al. 1976), MeWO (Bean et al. 1975), LB373Mel melanoma, Mel 85 (Lopes et al. 1991) e MZ2 (Herin et al. 1987). As linhagens de melanoma foram cultivadas em RPMI 1640 (SKMel 28, MeWO, LB373Mel melanoma e Mel 85) da Sigma-Aldrich $^{\circledR}$, Minimum Essential Medium Eagle - MEM (SKMel 37) da SigmaAldrich $^{\circledR}$ ou Dulbecco's Modified Eagle’s Medium - low glucose - DMEM (MZ2) da Sigma-Aldrich $^{\circledR}$, todos suplementado com 10\% de soro fetal bovino (SFB) (Cultilab ${ }^{\circledR}$ ), $25 \mathrm{mM}$ de HEPES (ácido N-2-hidroxietilpiperazina-N-2-etanosulfonico) e Bicarbonato de Sódio $24 \mathrm{mM}$. As culturas celulares forma mantidas em estufa de $5 \%$ de $\mathrm{CO}_{2}$. O descolamento das células para posterior contagem e subcultivo foi feito por curta exposição a PBS-EDTA. As células foram tratadas com $25 \mu \mathrm{M}$ de cisplatina por 24 horas, diluída em seus meios de cultura.

\subsection{Ensaio de Morte Celular}

Cerca de $1,5.10^{5}$ células foram cultivadas em placas de 6 poços onde foi feito o tratamento com $25 \mu \mathrm{M}$ de cisplatina por 24 horas. Após realizados os ensaios, as 
células foram fixadas em etanol $70 \%$, mantidas congeladas até o momento da análise por citometria de fluxo (citômetro FACScalibur Becton Dickson). O processo de morte foi avaliado pela incorporação de iodeto de propídio, que se incorpora estequiometricamente ao DNA, permitindo uma quantificação relativa do conteúdo de DNA de uma população de células. Células apresentando quantidade de DNA inferior a $2 \mathrm{n}$ (hipodiplóides $=\mathrm{H}_{0}$ ) foram consideradas em morte celular.

\subsection{Análise do Ensaio de morte Celular}

A análise da citometria de fluxo foi realizada usando-se programa Cell Quest Pro da Becton \& Dickinson ${ }^{\circledR}$. A caracterização das fases do ciclo celular foi realizada através de histogramas. Como ilustrado na figura 5, o primeiro segmento (M1) foi considerado como o segmento onde havia células com conteúdo de DNA abaixo de 2n, ou seja, em hipodiploidia. O segundo segmento (M2) foi definida pelo primeiro pico de eventos, onde havia células com conteúdo de DNA compatível com a fase G1 do ciclo celular. O terceiro segmento (M3) caracterizam as fases $\mathrm{S} / \mathrm{G} 2 / \mathrm{M}$ do ciclo celular. $\mathrm{O}$ quarto segmento (M4) caracterizam agregados celulares.

\section{Histograma}

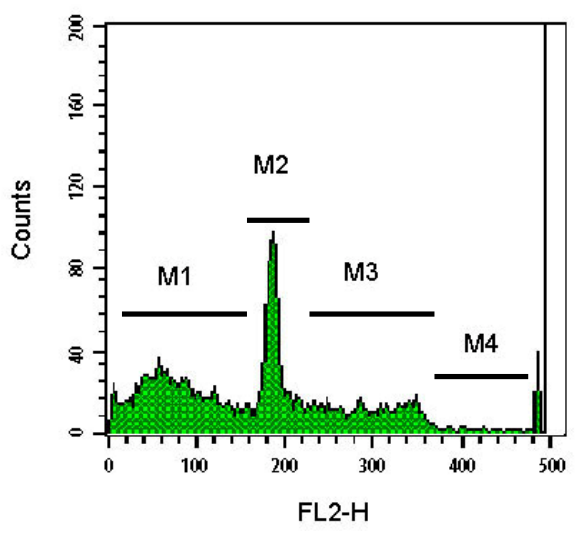

Figura 5. Esquema representativo da analise de ciclo celular através de um histograma. Adaptado de www.boku.ac.at/iam/poster/?C=M;O=D 
Algumas análises foram realizadas através de regiões, onde M1 e M4 foram descartadas e as novas análises foram feitas considerando-se apenas células viáveis. Nessa nova abordagem, M1 representa células na fase G1 do ciclo celular e M2 representa células nas fases $\mathrm{S} / \mathrm{G} 2 / \mathrm{M}$ do ciclo celular. No esquema abaixo, apenas os eventos dentro da região no Dot Plot (tipo de gráfico onde cada ponto representa uma célula) foram levados em conta para a formação do gráfico no histograma.
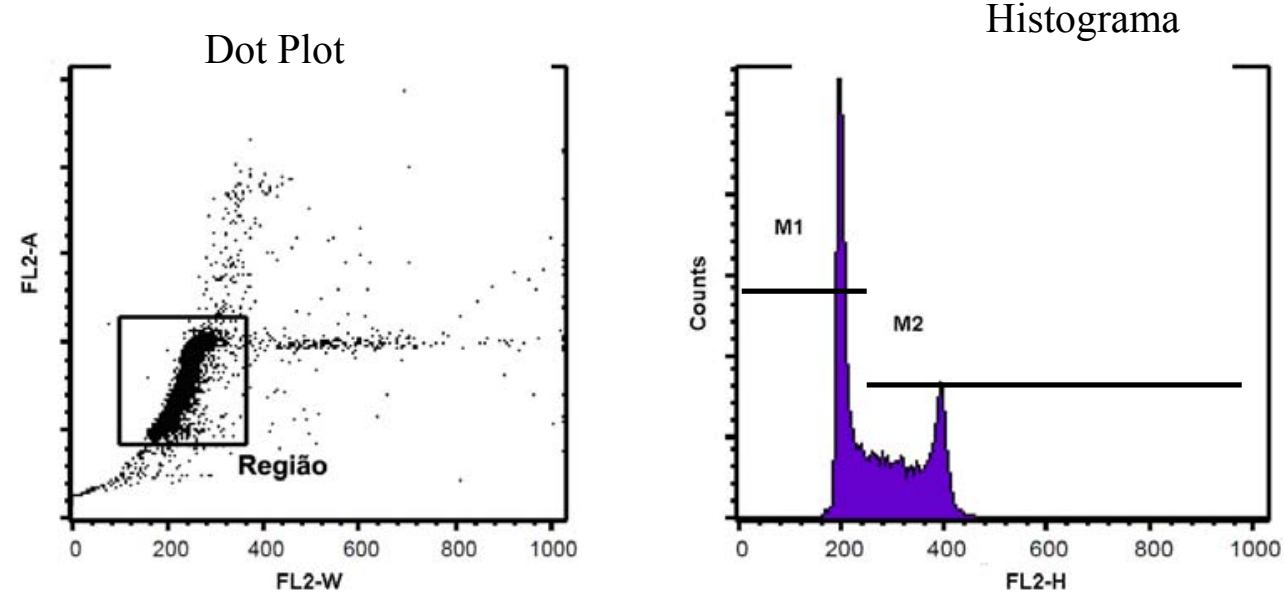

Figura 6. Esquema representativo de uma região. Adaptado de http://www.ucl.ac.uk/wibr/services/docs/cellcyc.pdf

\subsection{Anticorpos}

Três anticorpos contra proibitina foram utilizados. O anticorpo policlonal ab28172 (Abcam ${ }^{\circledR}$, www.abcam.com) foi utilizado nos ensaios de Western Blot. Para os ensaios de microscopia confocal, foi utilizado o anticorpo policlonal RB-292-P0 e o anticorpo monoclonal MS-261-P0, (Labvision Corporation ${ }^{\circledR}$, www.labvision.com). 
Para os ensaios de colocalização por microscopia confocal, foram utilizados o anticorpo policlonal ab2893 contra fosfo-histona $\gamma$-H2AX (Abcam ${ }^{\circledR}$, www.abcam.com) e o anticorpo policlonal sc-8349 contra Rad51 (Santa Cruz Biotechnology ${ }^{\circledR}$, Www.scbt.com).

Os anticorpos secundários utilizados nos ensaios de microscopia confocal foram: anti-mouse conjugado a Alexa Flúor 488 (verde) e anti-rabbit conjugado a Texas Red (vermelho) (Invitrogen ${ }^{\circledR}$, www.invitrogen.com). Para marcação. Para marcação do núcleo nesses ensaios, foi utilizado o 4',6-diamidino-2-phenylindole (DAPI).

O anticorpo monoclonal A1978 contra $\beta$-actina (Sigma-Aldrich $^{\circledR}$, www.sigmaaldrich.com) foi utilizado como controle de massa dos ensaios de Western Blot.

\subsection{Extração de Proteínas}

Aproximadamente $1 \times 10^{7}$ células foram tripsinizadas, centrifugadas e ressuspendidas em tampão hipotônico (1mM HEPES; 1mM KCl; 0,1mM EDTA, pH 7,5,) no qual inibidores de protease foram adicionados (1mM DTT; 0,1 mM PMSF, 5ug/ml de aprotinina; $2.5 \mathrm{mM}$ pepstatina, 20ug/ml antipaína; e $1 \mathrm{mM}$ leupeptina). As células foram homogeneizadas e colocadas a $4^{\circ} \mathrm{C}$ por 15 minutos. $\mathrm{O}$ homogenato foi centrifugado a $4^{\circ} \mathrm{C}$ por 15 minutos a 13000rpm. O sobrenadante obtido desta centrifugação (extrato citoplasmático) foi aliquotado. O precipitado originado foi ressuspendido com tampão de lise nuclear (HEPES 10mM, EDTA 5mM, KCl 150 mM, SDS $0,05 \%$, Triton 1\%, NaF 20mM, Pirofosfato de Sódio 20mM e Molibdato de Sódio $20 \mathrm{mM}$ ) no qual inibidores de protease foram adicionados (1mM DTT; 0,1 mM PMSF, 5ug/ml de aprotinina; 2.5mM pepstatina, 20ug/ml antipaína; e $1 \mathrm{mM}$ leupeptina) e 
colocado a $4^{\circ} \mathrm{C}$ por 15 minutos. Após os 15 minutos, o material foi centrifugado a $4^{\circ} \mathrm{C}$ por 15 minutos a 13000rpm. O sobrenadante obtido (extrato nuclear) foi misturado ao extrato citoplasmático e conservado a $-20^{\circ} \mathrm{C}$ até o momento do uso.

\subsection{Dosagem Protéica}

A dosagem de proteinas foi realizada utilizando-se o kit Reagente BCA para Ensaio de Proteínas (Lowry modificado), da BioAgency ${ }^{\circledR}$, de acordo com o manual do fabricante. Para leitura das amostras, foi utilizado um leitor de microplacas (Bio-RAD ${ }^{\circledR}$, www.bio-rad.com) utilizando-se filtros de 592nm.

\subsection{Gel de Poliacrilamida e Western Blot}

Foram realizadas análises de proteínas separadas de acordo com sua massa molecular aparente (SDS-PAGE). As amostras de extratos protéicos foram separadas em gel de poliacrilamida, $\mathrm{O}$ gel de corrida contém Tris $0,375 \mathrm{M}$ pH 8,8, SDS 0,1\%, acrilamida 10\%, Persulfato de Amônio (APS) $0,03 \%$ em,N,N,N tetra metilenodiamina (TEMED, Sigma $^{\circledR}$ ); e o gel de empilhamento, TRIS 0,125 M pH 6,8, SDS 0,1\%, acrilamida 4\%, APS 0,045\%, e TEMED. Em seguida, os extratos protéicos separados transferidos para a membrana PVDF (Hydrophobic polyviniylidene difluoride, Amershan $^{\circledR}$ ) para a realização do blotting, sendo feita em tampão Tris $25 \mathrm{mM}$, metanol $20 \%$ por uma hora a $100 \mathrm{~V}$ e a $4^{\circ} \mathrm{C}$. 
A membrana teve seus sítios inespecíficos bloqueado com leite Molico 5\% em PBS-Tween $0,5 \%$ e incubada com o anticorpo policlonal anti-PHB O.N. e contra $\beta$ Actina por 1 hora e meia à temperatura ambiente. Posteriormente, a membrana foi incubada com o anticorpo secundário policlonal de coelho conjugado a peroxidase por uma hora. A revelação da membrana foi feita utilizando-se o ECL ${ }^{\mathrm{TM}}$ Western Blotting system da $\mathrm{GE}^{\circledR}$. Como controle da reação, foi utilizado um padrão conhecido de peso molecular.

\subsection{Microscopia Confocal}

Cerca de $7,0.10^{4}$ células foram plaqueadas em placa de 24 poços em condição de cultura com e sem tratamento com $25 \mu \mathrm{M}$ de Cisplatina por 24 horas. Mitotracker Red CMXRos da Invitrogen ${ }^{\circledR}$ foi utilizado ainda na placa de cultura por 45 minutos antes da fixação das células como marcador de mitocôndria, na concentração de $0,5 \mu \mathrm{M}$. As células foram fixadas em 3,5\% de formaldeído em PBS. Em seguida, após serem lavadas $3 \mathrm{x}$ com PBS, foi adicionado Triton X-100/PBS $0.2 \%$ por 5 minutos. O Bloqueio de sítios inespecíficos foi feito com PBS/BSA 5\% por 1 hora. Após isso, foi adicionado o anticorpo primário policlonal ou monoclonal anti-PHB, anti- $(\gamma-\mathrm{H} 2 \mathrm{AX})$ ou antiRAD51, diluídos em PBS/BSA 5\% O.N. a $4^{\circ} \mathrm{C}$. Depois de lavadas 3 vezes com PBS/BSA 1\%, foi adicionado o anticorpo secundário conjugado com Alexa Flúor 488 ou Texas Red, de acordo com a origem do anticorpo primário. Após serem lavadas novamente com PBS/BSA 1\%, foi adicionado DAPI por 15 minutos diluído em com PBS/BSA 5\%. Por último, foram montadas as lâminas. A análise foi realizada em microscópio confocal ZEISS LSM 510 Meta / UV. 
A calibração do equipamento foi feita de modo a não haver excesso de intensidade de fluorescência captada pelo microscópio nos ensaios onde há tratamento com cisplatina, pois é onde se espera que haja maior intensidade de fluorescência em todas as marcações realizadas.

\subsection{Ensaio com siRNA}

Cerca de $1,0.10^{5}$ células foram plaqueadas em placa de 6 poços. Em dois dos seis poços não foram feitos qualquer transfecção, em dois poços foram transfectados com o siRNA controle que não reconhece seqüência de RNA humana (Dharmacon ${ }^{\circledR}$ ) e nos outros dois poços houve a transfecção com siRNA contra proibitina, da IDT ${ }^{\circledR}$. Como veículo, foi utilizado lipofectamina ${ }^{\mathrm{tm}} 2000$, da Invitrogen $^{\circledR}$. Misturou-se a lipofectamina e o siRNA controle (350 pmol/poço) e o siRNA contra proibitina (350 pmol/poço) em tubos eppendorfs com Opti-MEM, da Invitrogen ${ }^{\circledR}$, separados, por 15 minutos. Os tubos com lipofectamina e com o respectivo siRNA foram misturados e após 15 minutos, o siRNA misturado com a lipofectamina foi adicionado ao poço contendo Opti-MEM sem soro fetal bovino. Após seis horas, adicionou-se o soro fetal bovino nos poços, na concentração final de $10 \%$ e a placa foi mantida O.N. em estufa. No dia seguinte, as células que estavam aderidas foram plaqueadas em placa de 12 poços, onde uma parte dessas células foi preparada em triplicatas para a realização da citometria de fluxo e outra parte, para extração de proteínas. Após a adesão dessas células, foi feito o tratamento com $25 \mu \mathrm{M}$ de cisplatina por 24 horas.

A seqüência do siRNA contra proibitina utilizada é a seguinte:

5' - CACAUUAUAUAAGGCAGAGUUTT - 3'

3' - TTGUGUAAUAUAUUCCGUCUCAA - 5' 


\subsection{Análise Estatística}

Todas as análises estatísticas foram feitas utilizando-se o programa GraphPad Prism $^{\circledR}$ versão 4.00 (www.graphpad.com), através de ANOVA. Considerou-se um nível de significância, $\alpha=0.05$. 


\section{RESULTADOS}

\subsection{Ensaio de morte celular (FACS)}

Verificou-se por citometria de fluxo, a capacidade da cisplatina em levar linhagens de melanoma metastático humano à morte. As linhagens SKMel37, LB373Mel, Mel85, MZ2 e MeWO foram submetidas a tratamento com $25 \mu \mathrm{M}$ de cisplatina por 24 horas com seus respectivos controles (sem tratamento). A morte celular foi analisada por Iodeto de Propídio (PI) pela marcação do segmento M1 do histograma, onde é representada a população de células hipodiplóides. 


\section{Controle}

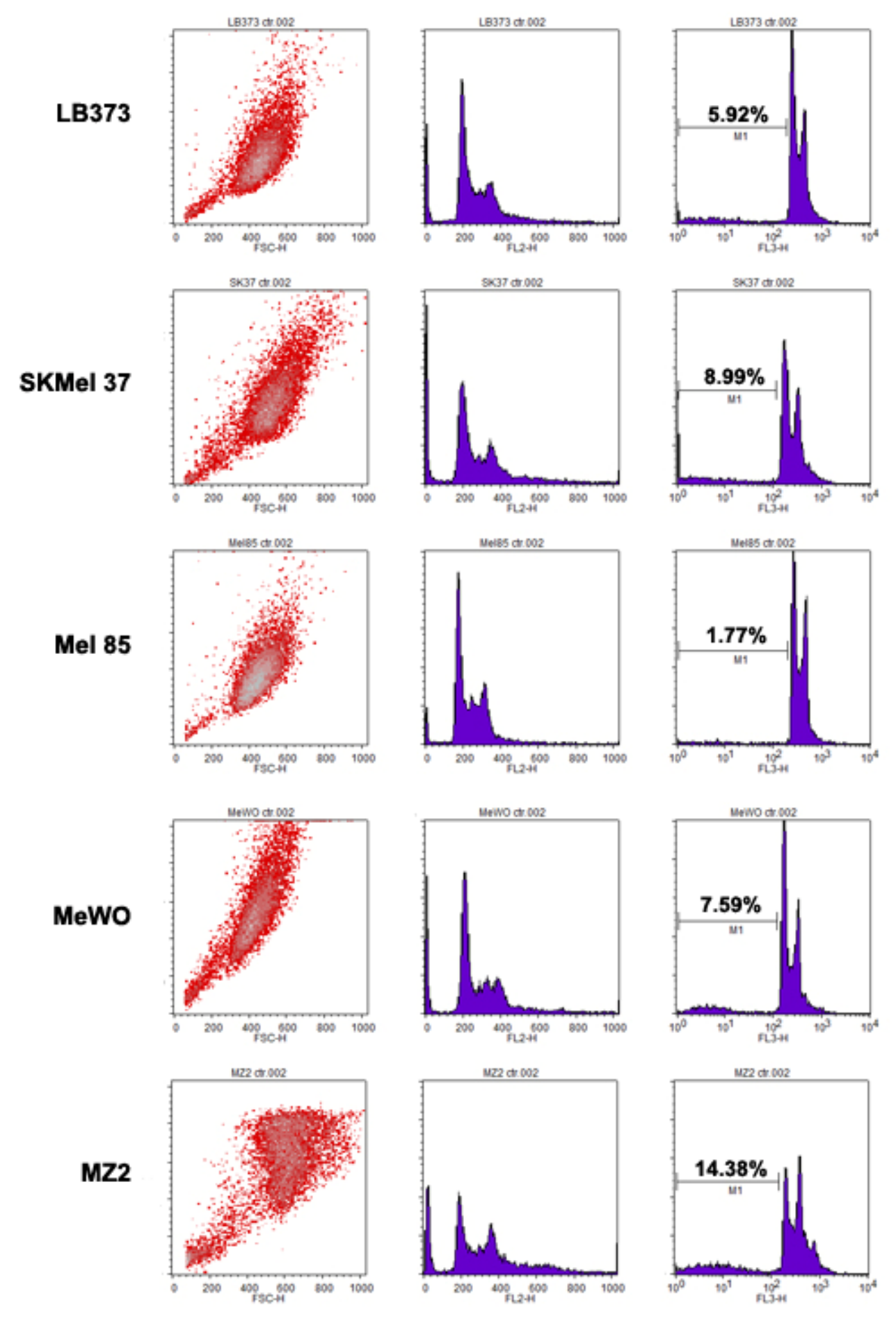

Figura 6. Análise representativa da citometria de fluxo das linhagens LB373Mel, SKMel 37, Mel 85, MeWO e MZ2 sem tratamento com cisplatina. Cada análise representa uma das triplicatas de cada linhagem celular. M1: porcentagem de células em hipodiploidia. 


\section{Cisplatina}

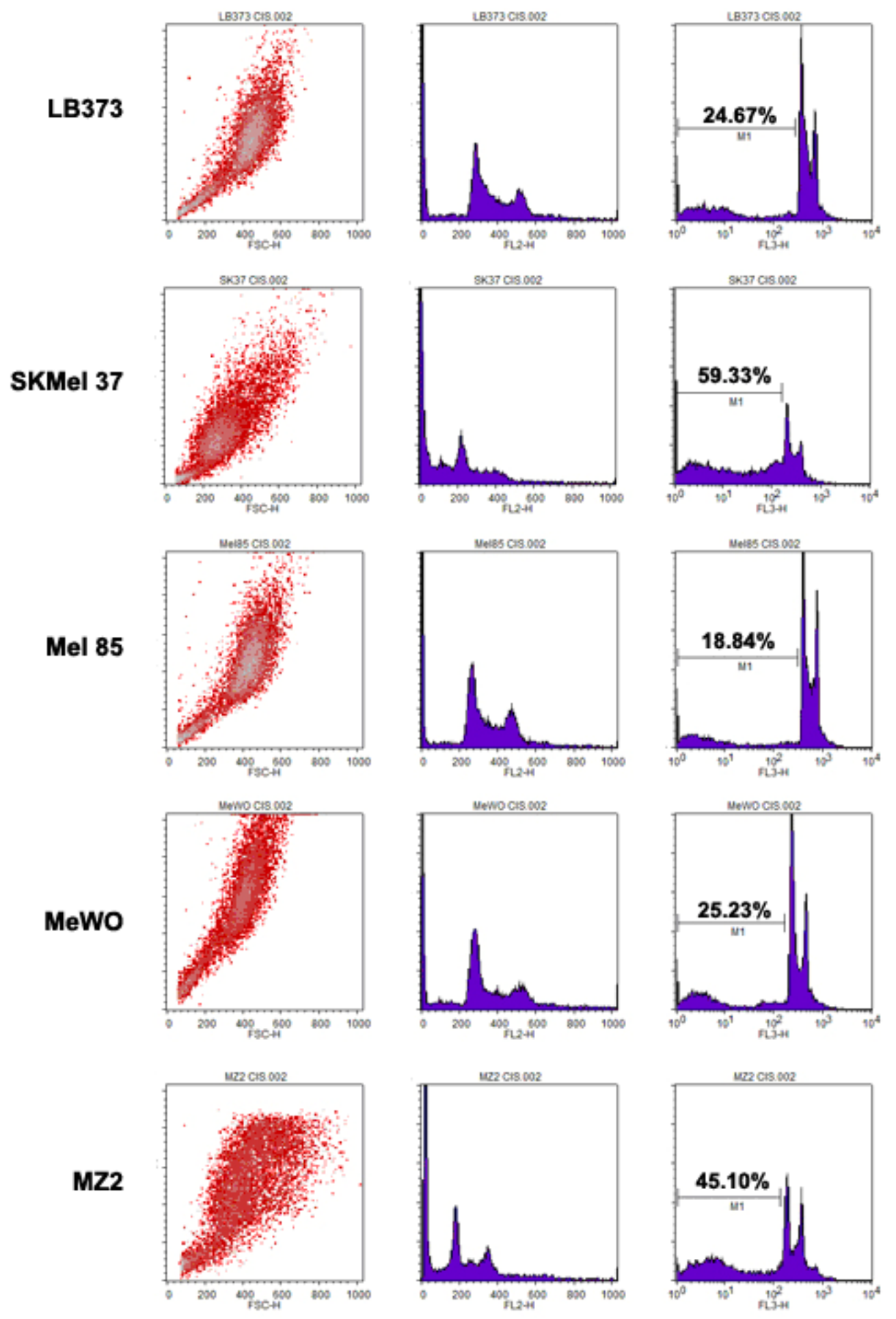

Figura 7. Análise representativa da citometria de fluxo das linhagens LB373Mel, SKMel 37, Mel 85, MeWO e MZ2 após tratamento com cisplatina por 24 horas. Cada análise representa uma das triplicatas de cada linhagem celular. M1: porcentagem de células em hipodiploidia. 
Após a citometria, foi feita uma análise estatística dos valores encontrados. Foi feito uma comparação da quantidade de eventos no segmento M1 (hipodiploidia) na presença ou ausência de cisplatina para se saber como essas linhagens se comportam após o tratamento. O gráfico gerado pode ser visto na figura 8 .

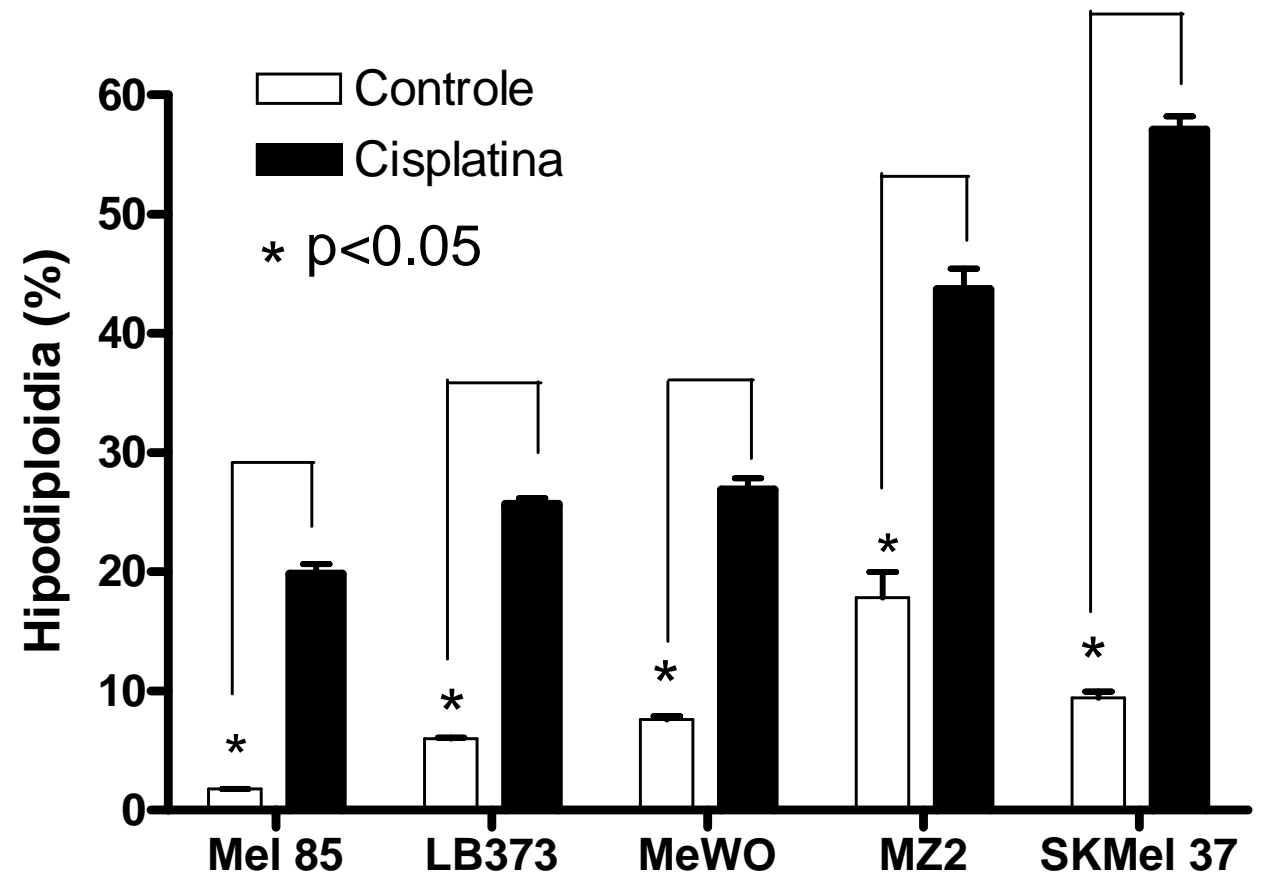

Figura 8. Análise estatística da região M1 na presença (preto) ou ausência (branco) de tratamento com $25 \mu \mathrm{M}$ de cisplatina por 24 horas.

A figura 8 mostrou que houve diferença na capacidade de sobrevivência das linhagens de melanoma humano frente à cisplatina. Em todas as linhagens, houve variação estatística significativa $(\mathrm{p}<0.05)$ nos níveis de morte celular após tratamento. A linhagem SKMel 37 foi a que mais se mostrou sensível frente à droga e a linhagem Mel 85, a menos sensível. A figura 8 mostrou também que há diferença na quantidade de células em hipodiploidia mesmo na ausência de cisplatina. 
Para verificar o acúmulo de células nas fases S/G2/M do ciclo celular causado pela cisplatina, fizemos uma análise através de uma região, onde foram desconsideradas as subpopulações em hipodiploidia e os agregados celulares. Com isso, verificamos a porcentagem de células viáveis na fase $\mathrm{G} 1$ ou S/G/2M do ciclo celular e verificamos se há diferenças nessas populações após tratamento com cisplatina. 


\section{Controle}
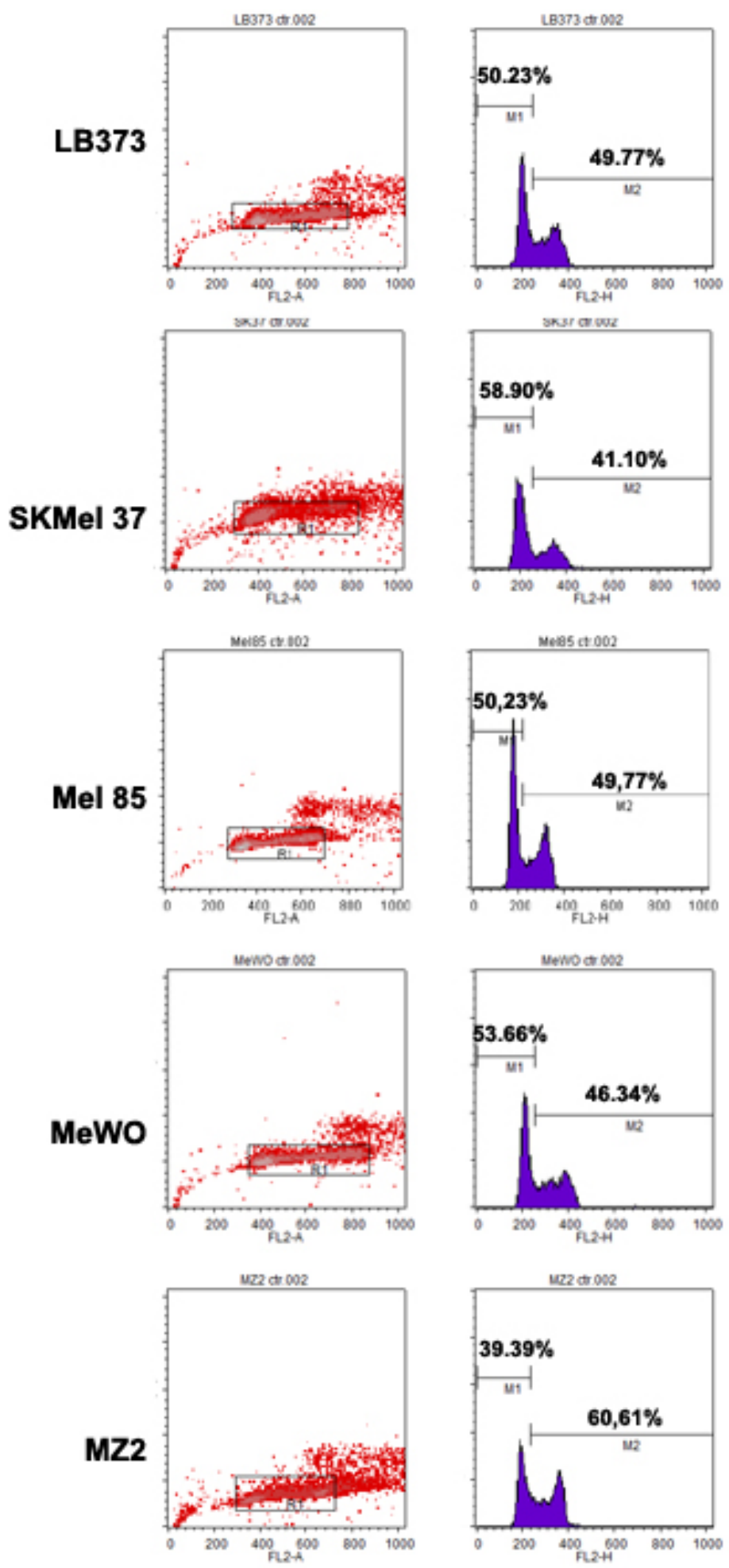

Figura 9. Análise do ciclo celular das linhagens LB373Mel, SKMel 37, Mel 85, MeWO e MZ2, através de uma região, na ausência de tratamento com cisplatina. M1: fase G1 do ciclo celular. M2: fase S, G2 ou M do ciclo celular. A porcentagem indica o numero de células nas regiões $\mathrm{M} 1$ ou M2 em relação à quantidade de células dentro de cada região, indicado pela letra $\mathrm{R}$. 


\section{Cisplatina}
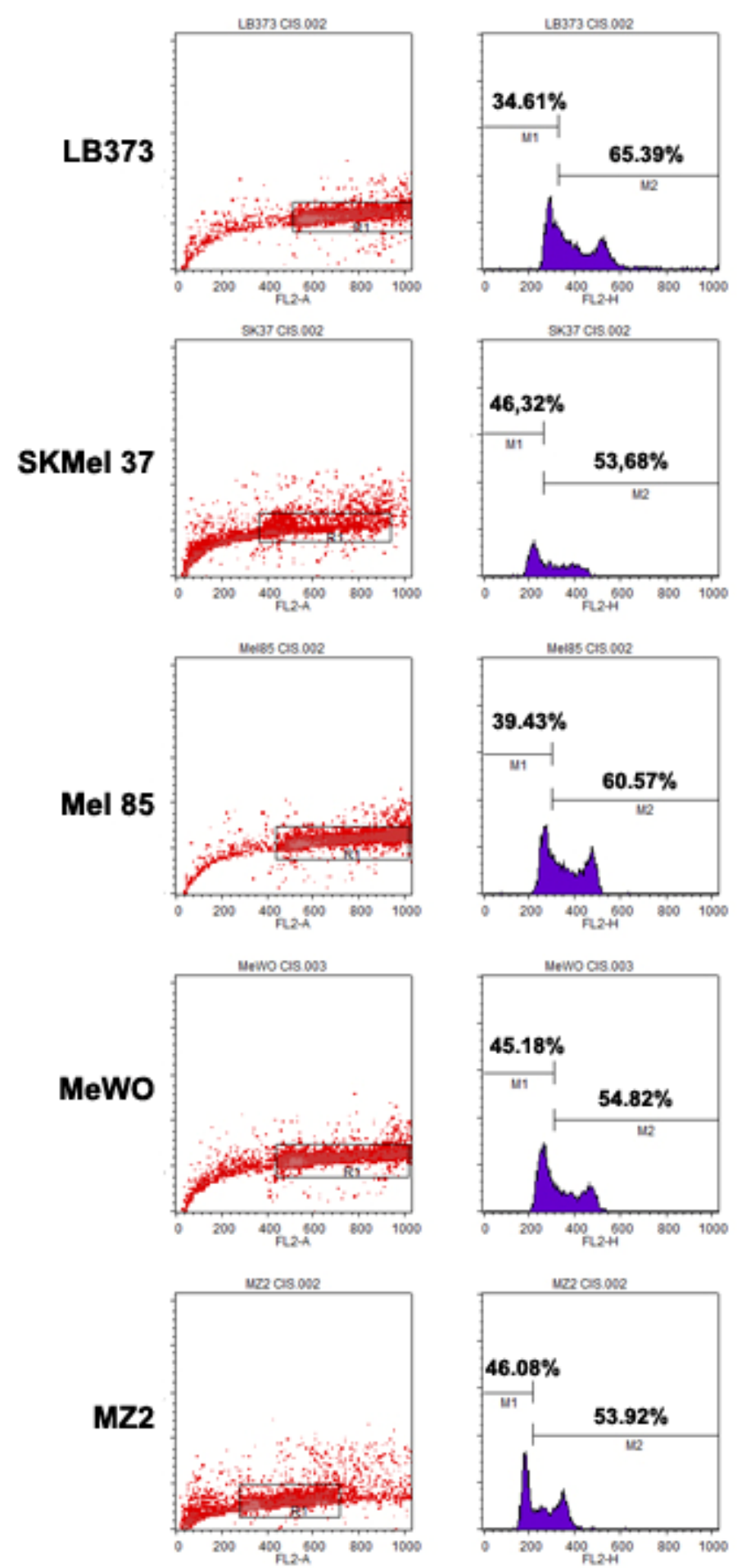

Figura 10. Análise do ciclo celular das linhagens LB373Mel, SKMel 37, Mel 85, MeWO e MZ2 através de uma região, após tratamento com $25 \mu \mathrm{M}$ de cisplatina. M1: fase G1 do ciclo celular. M2: fase S, G2 ou M do ciclo celular. A porcentagem indica o numero de células nas regiões $\mathrm{M} 1$ ou M2 em relação à quantidade de células dentro de cada região, indicado pela letra $\mathrm{R}$. 
As figuras 9 e 10 representam um gráfico de cada triplicata analisada. A análise estatística das triplicatas permitiu que o gráfico da figura 11 fosse gerado.

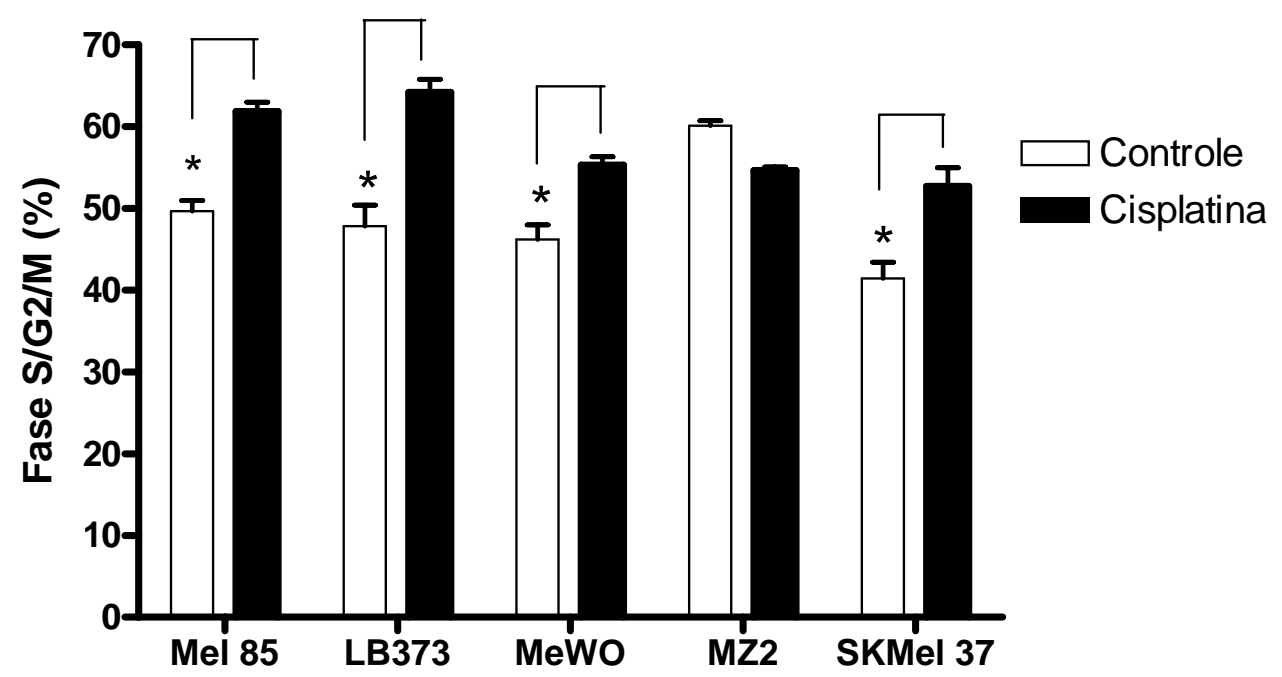

Figura 11. Porcentagem de células na fase $S / G 2 / M$ antes e após tratamento com cisplatina, representando a quantidade total de células viáveis nessas fases do ciclo celular.

A figura 11 mostra que apenas a linhagem MZ2 não acumulou células nas fases $\mathrm{S} / \mathrm{G} 2 \mathrm{M}$ do ciclo celular após tratamento com cisplatina. Todas as outras linhagens obtiveram um valor estatístico significante $(\mathrm{p}<0.05)$ tendendo a acumular-se em $\mathrm{S} / \mathrm{G} 2 / \mathrm{M}$ após tratamento com cisplatina.

A partir dos dados de citometria de fluxo as linhagens SKMel 37, Mel85 e LB37Mel foram analisadas mais detalhadamente em relação à expressão e à localização intracelular de proibitina após tratamento com cisplatina. 


\subsection{Análise da expressão de proibitina após tratamento com cisplatina.}

Extratos protéicos totais das linhagens LB373Mel, SKMel 37 e Mel85 foram feitos para se determinar se há diferença na expressão de proibitina após tratamento com $25 \mu \mathrm{M}$ de cisplatina por 24 horas. O western blot resultante pode ser visto na figura 12 . Mediu-se valor relativo (R) da variação do nível de expressão de proibitina após tratamento com cisplatina em relação ao controle (sem tratamento) em uma mesma linhagem. Como controle de massa, foi utilizado o nível de expressão de $\beta$-actina.

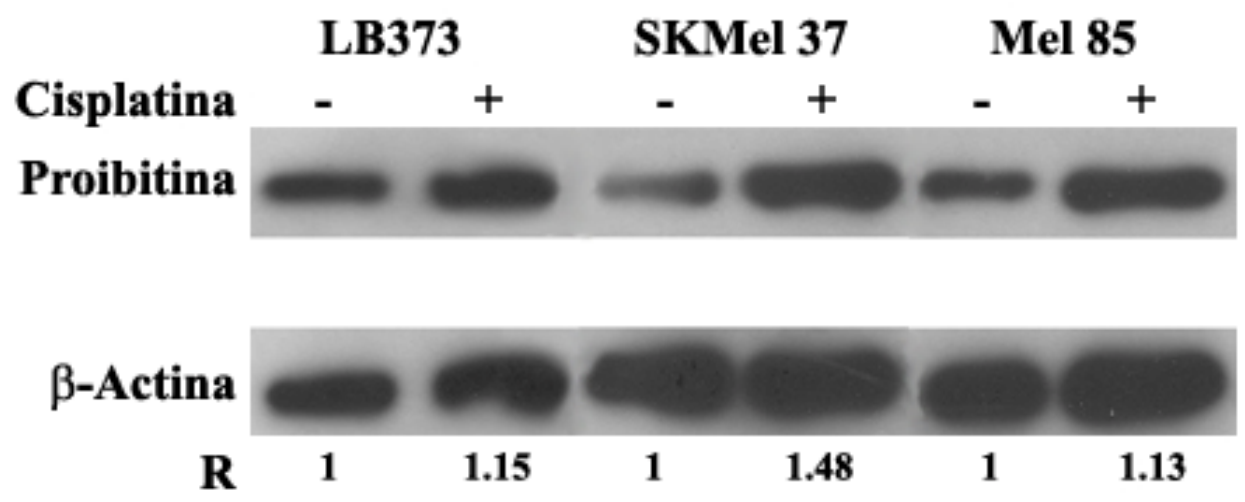

Figura 12. Western blot de extrato protéico das linhagens LB373Mel, SKMel 37 e Me185 na presença ou ausência de tratamento com cisplatina. R: valor relativo da expressão de proibitina comparada dentro de uma mesma linhagem. $\beta$-actina: controle de massa.

Como mostrado na figura 12 , houve aumento no nível de expressão de proibitina após tratamento com cisplatina em todas as linhagens analisadas, apesar da intensidade desse aumento variar. O maior aumento observado após tratamento com cisplatina foi na linhagem SKMel 37, com 48\%. AS linhagens LB373Mel e Mel85 obtiveram 15\% e $13 \%$ de aumento, respectivamente. 


\subsection{Determinação da localização celular da proibitina.}

Para se determinar a localização celular da proibitina foram realizados ensaios de microscopia confocal, utilizando-se anticorpos poli e monoclonal contra proibitina.

As linhagens de melanoma humano LB373Mel, SKMel 37 e Me185 foram plaqueadas e submetidas ou não ao tratamento com cisplatina. A proibitina foi marcada O.N. utilizando-se um anticorpo policlonal. Foram utilizados marcadores para a mitocôndria (Mitotracker Red CMXRos, da Invitrogen ${ }^{\circledR}$ ) e para o núcleo (DAPI). 


\section{LB373 \\ Cisplatina}
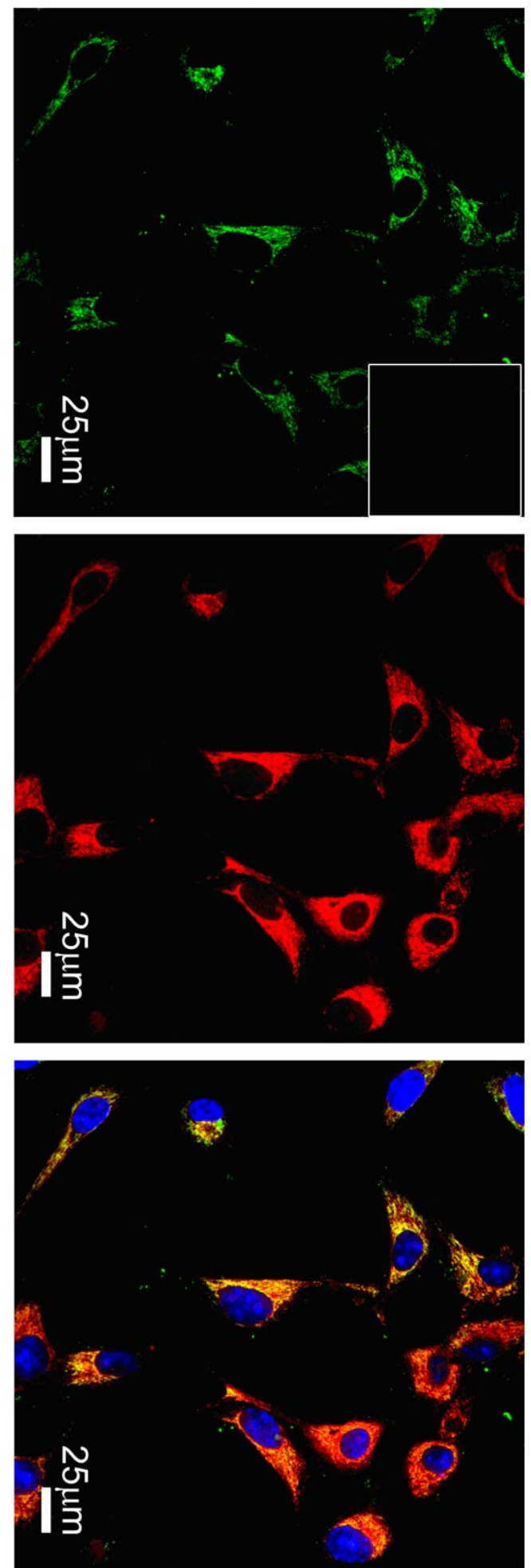

LB373

Controle
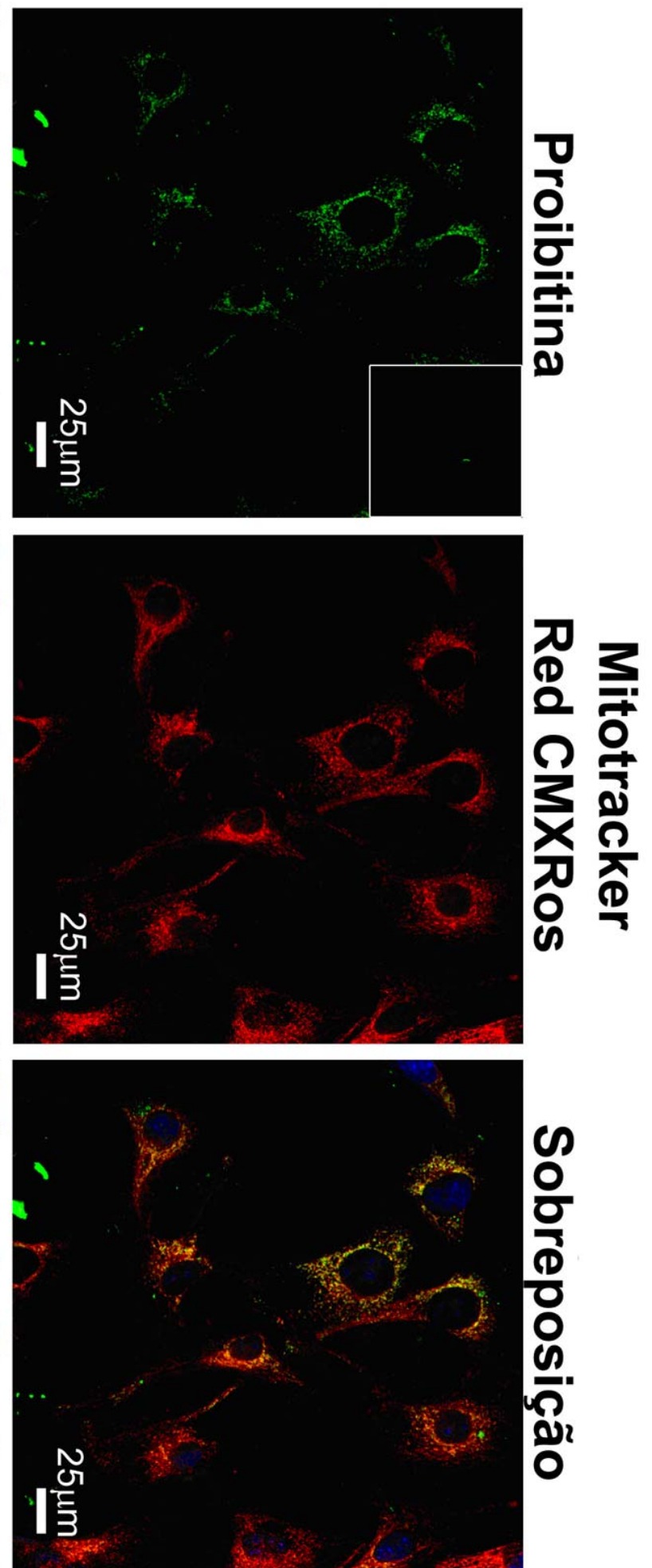

Figura 13. Microscopia confocal da linhagem LB373Mel na presença ou ausência de cisplatina. Proibitina em verde, Mitotracker Red CMXRos ${ }^{\circledR}$ em vermelho e DAPI em Azul. Sobreposição: junção das micrografias representando a marcação com anticorpo anti-proibitina e Mitotracker Red CMXRos ${ }^{\circledR}$. Controle negativo dentro da moldura branca. A barra branca representa $25 \mu \mathrm{M}$. 


\section{SKMel37 \\ Cisplatina}
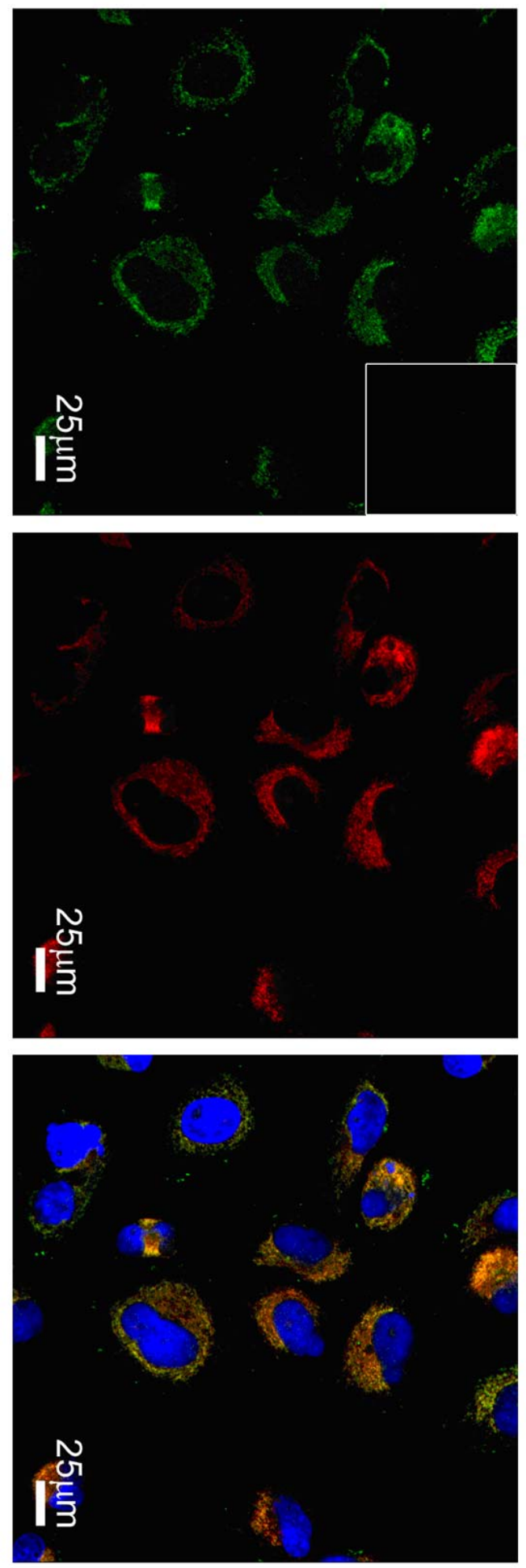

\section{SKMel37}

Controle
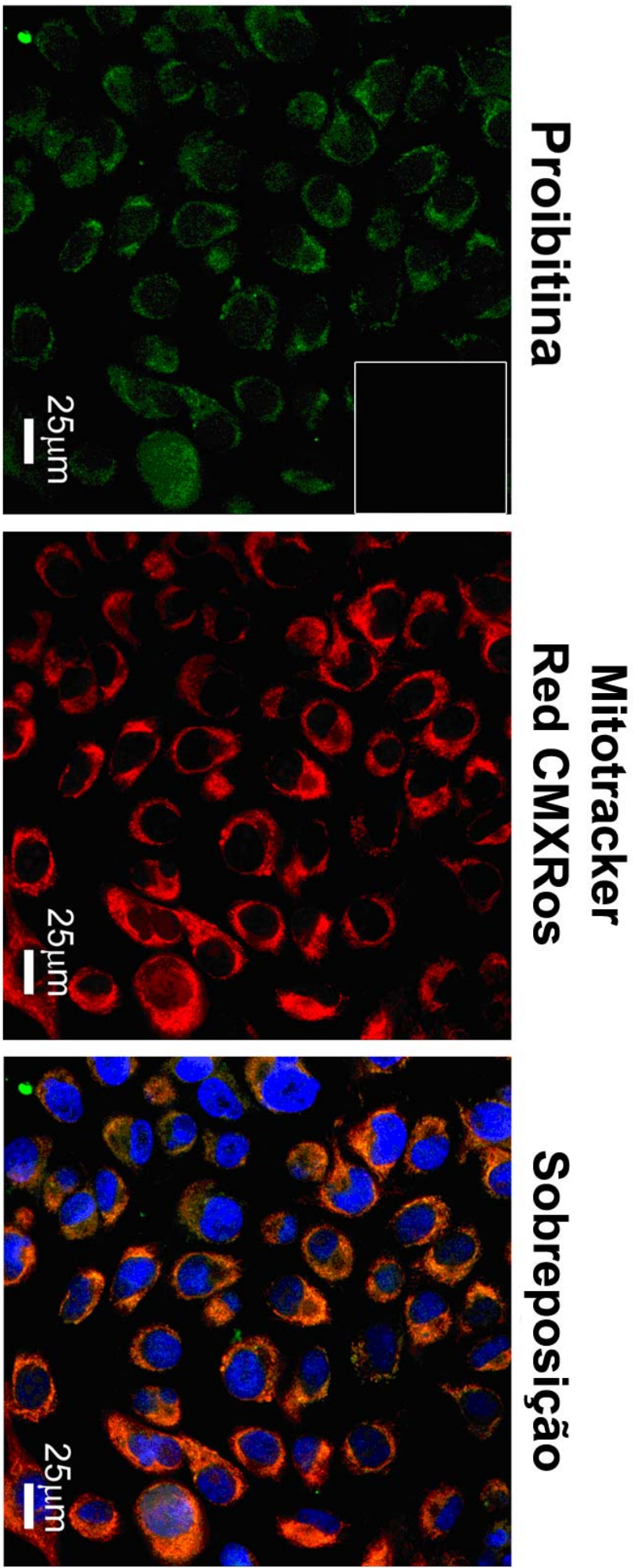

Figura 14. Microscopia confocal da linhagem SKMel 37 presença ou ausência de cisplatina. Proibitina em verde, Mitotracker Red CMXRos ${ }^{\circledR}$ em vermelho e DAPI em Azul. Sobreposição: junção das micrografias representando a marcação com anticorpo anti-proibitina e Mitotracker Red CMXRos ${ }^{\circledR}$. Controle negativo dentro da moldura branca. A barra branca representa $25 \mu \mathrm{M}$. 


\section{Mel 85 Cisplatina}
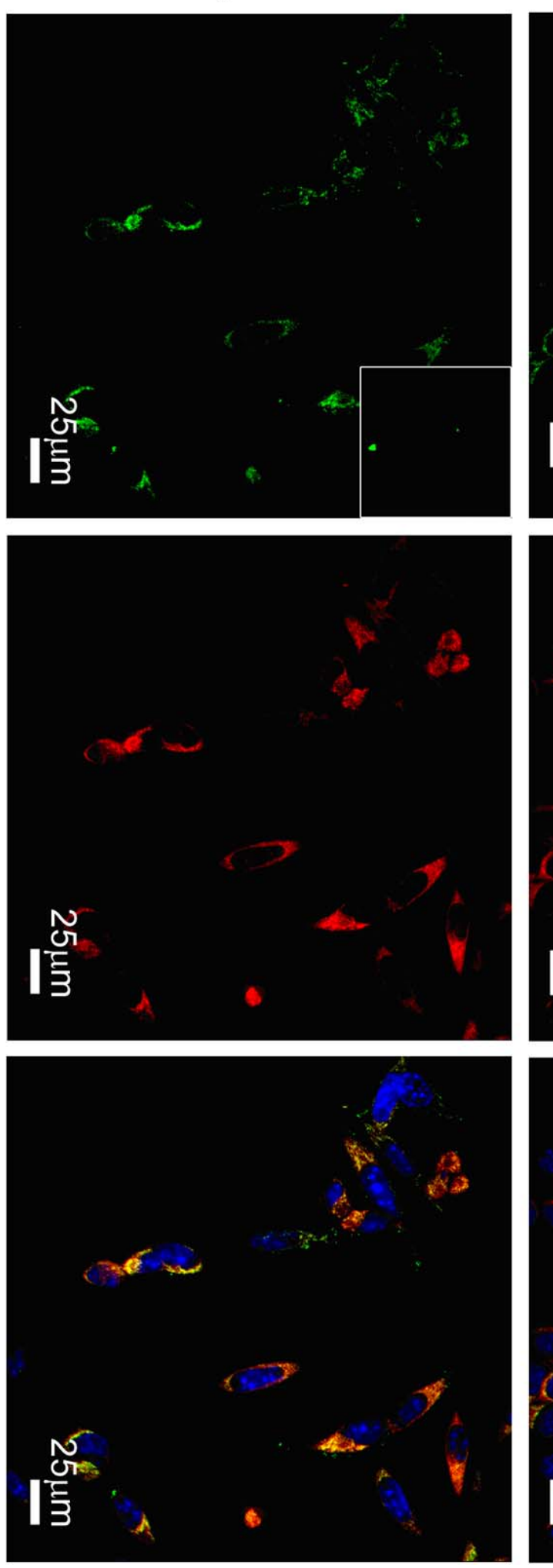

\section{Mel 85 \\ Controle}
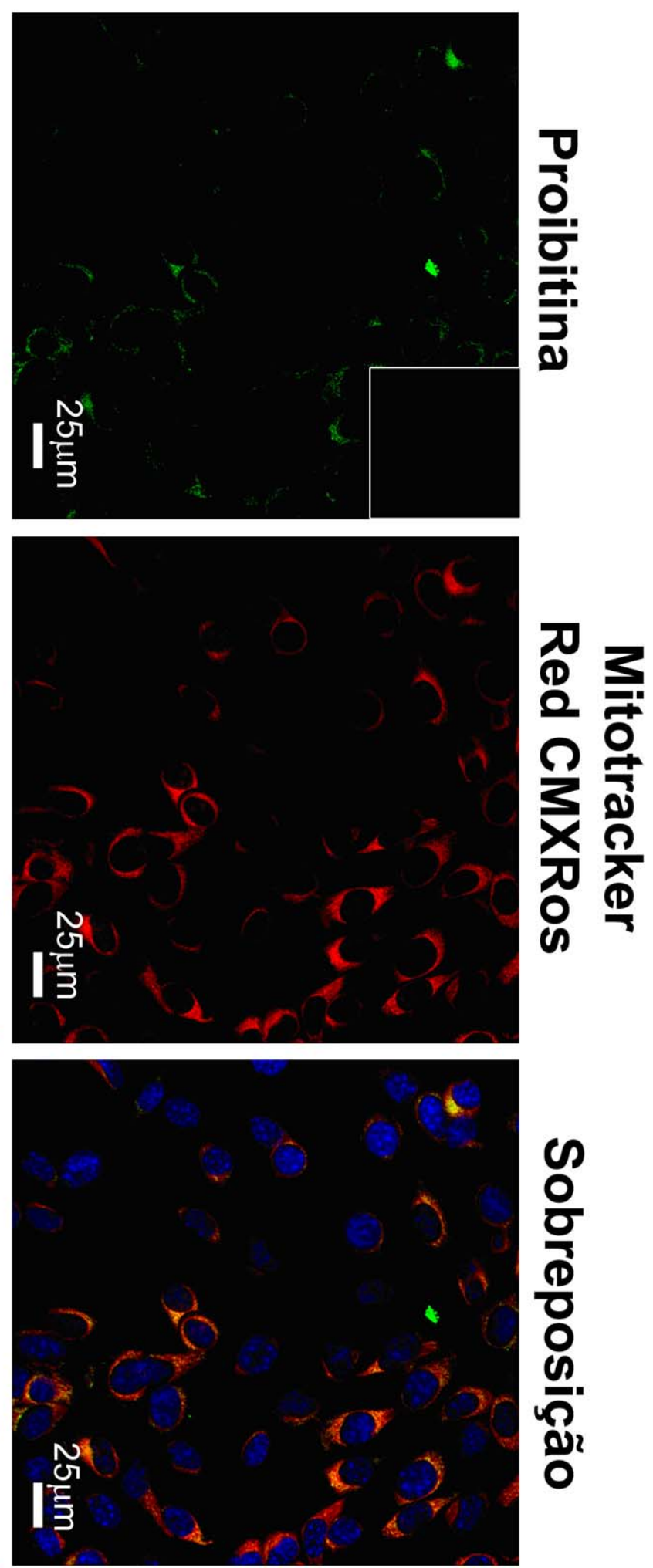

C
0
0
$\frac{1}{10}$
0
0
0
$\frac{0}{2}$
0
0

Figura 15. Microscopia confocal da linhagem Mel 85 presença ou ausência de cisplatina. Proibitina em verde, Mitotracker Red CMXRos ${ }^{\circledR}$ em vermelho e DAPI em Azul. Sobreposição: junção das fotos Proibitina e Mitotracker Red CMXRos ${ }^{\circledR}$. Controle negativo dentro da moldura branca. A barra branca representa $25 \mu \mathrm{M}$. 
As figuras 13, 14 e 15 mostraram que o anticorpo policlonal utilizado reconheceu preferencialmente a proibitina localizada no, pois não há colocalização com o marcador de núcleo DAPI. Houve uma suposta colocalização com a mitocôndria em todas as linhagens, observada pela mudança da tonalidade de cor de verde/vermelho para o alaranjado, onde há junção das imagens. Não houve mudança de padrão de localização da proibitina após tratamento com cisplatina.

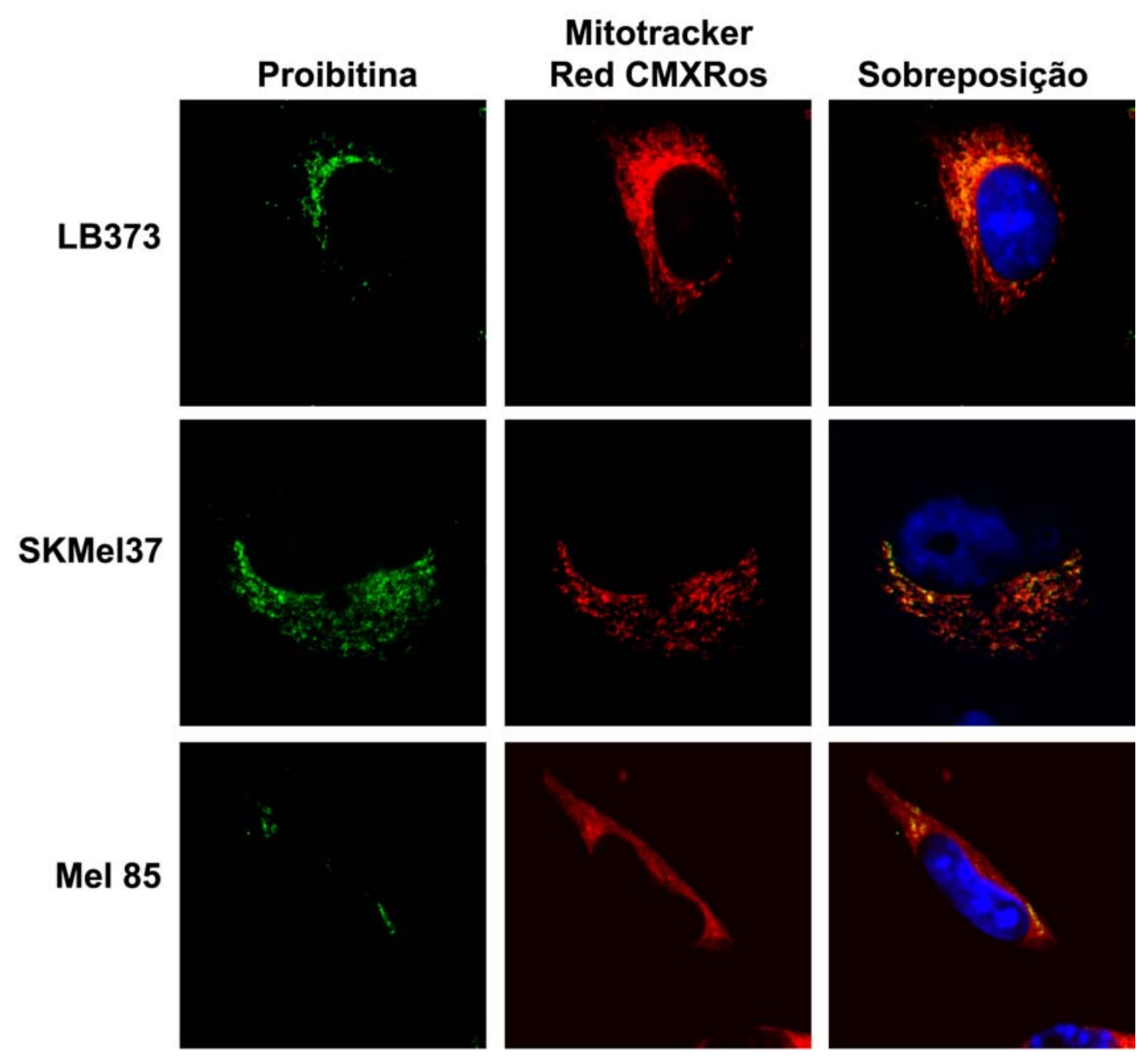

Figura 16. Ampliação de 4x da micrografia das linhagens LB373Mel, SKMel 37 e Mel 85. Proibitina em verde, Mitotracker Red CMXRos ${ }^{\circledR}$ em vermelho e DAPI em Azul. Sobreposição: junção das micrografias representando a marcação com anticorpo anti-proibitina e Mitotracker Red CMXRos ${ }^{\circledR}$. Todas as linhagens foram tratadas com cisplatina. 
A figura 16 mostra uma ampliação de quatro vezes feita pelo microscópio confocal. Dessa forma, pode-se mostrar melhor a localização citoplasmática da proibitina e sua possível colocalização com a mitocôndria.

Para se confirmar a colocalização da proibitina com a mitocôndria foi feito uma análise em z-stack pelo microscópio confocal. Esse método permite que a célula seja lida pelo laser em diferentes camadas de cerca de $0.50 \mu \mathrm{m}$ cada. O resultado pode ser visto na figura 17.

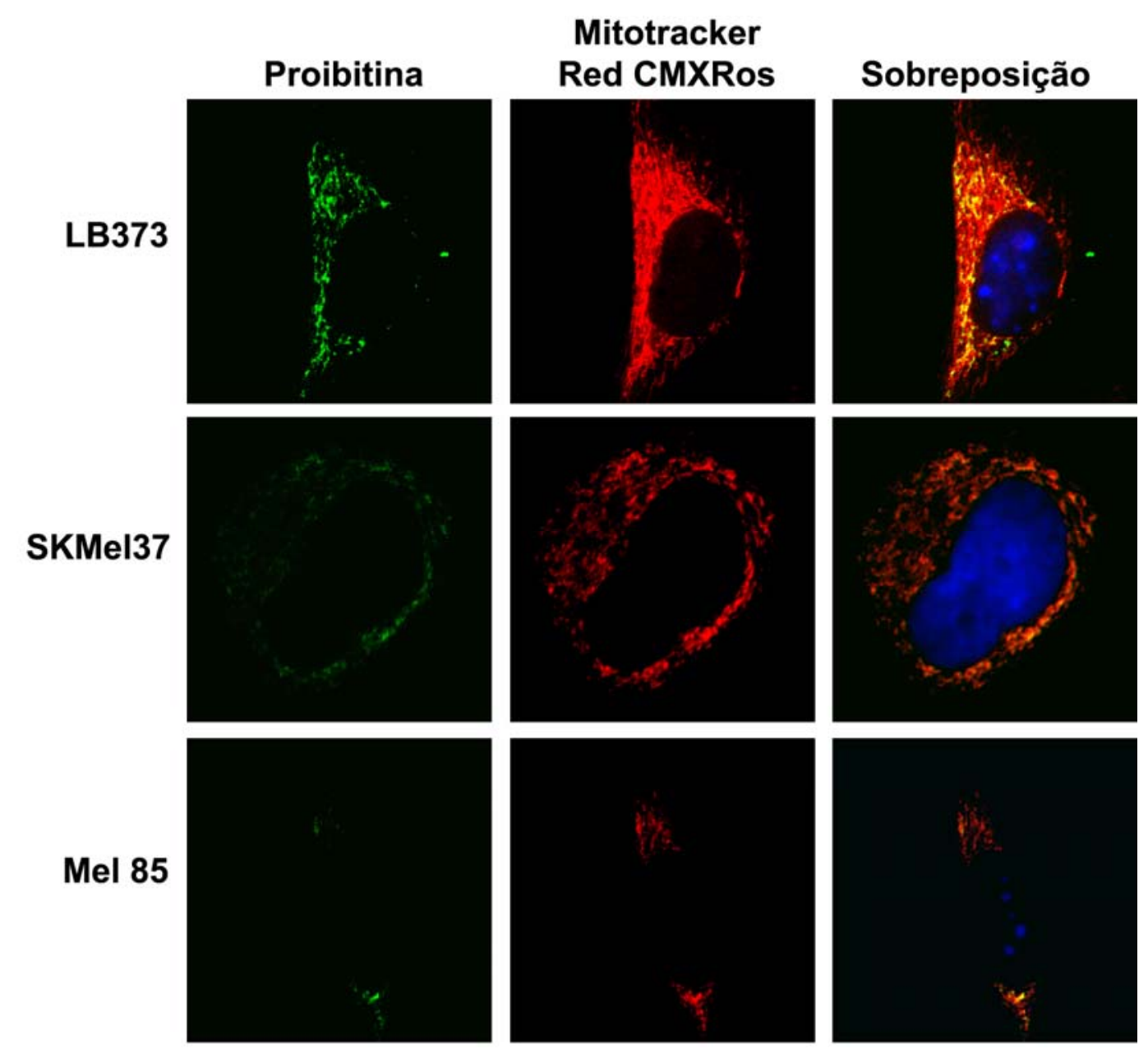

Figura 17. Micrografia representativa de análise por camadas (z-stack) realizada por microscopia confocal nas linhagens LB373Mel melanoma, SKMel 37 e Mel 85 após tratamento com cisplatina. Proibitina em verde, mitocôndria em vermelho e DAPI em Azul. Sobreposição: junção das micrografias representando a marcação com anticorpo anti-proibitina e Mitotracker Red CMXRos ${ }^{\circledR}$. Ampliação de 4x. 
A análise por camadas (z-stack) confirmou a colocalização da proibitina com a mitocôndria nas linhagens LB373Mel, SKMel 37 e Mel 85. Mostrou também que não há evidencia de localização nuclear de proibitina ao se utilizar o anticorpo policlonal.

Um segundo anticorpo contra proibitina, dessa vez monoclonal, foi utilizado para se determinar sua localização celular. As mesmas linhagens foram novamente analisadas, nas mesmas condições, apenas com a diferença do anticorpo primário. As figuras 18, 19 e 20 mostram o resultado da microscopia confocal nas linhagens LB373Mel, SKMel 37 e Mel 85. 


\section{LB373}

Cisplatina
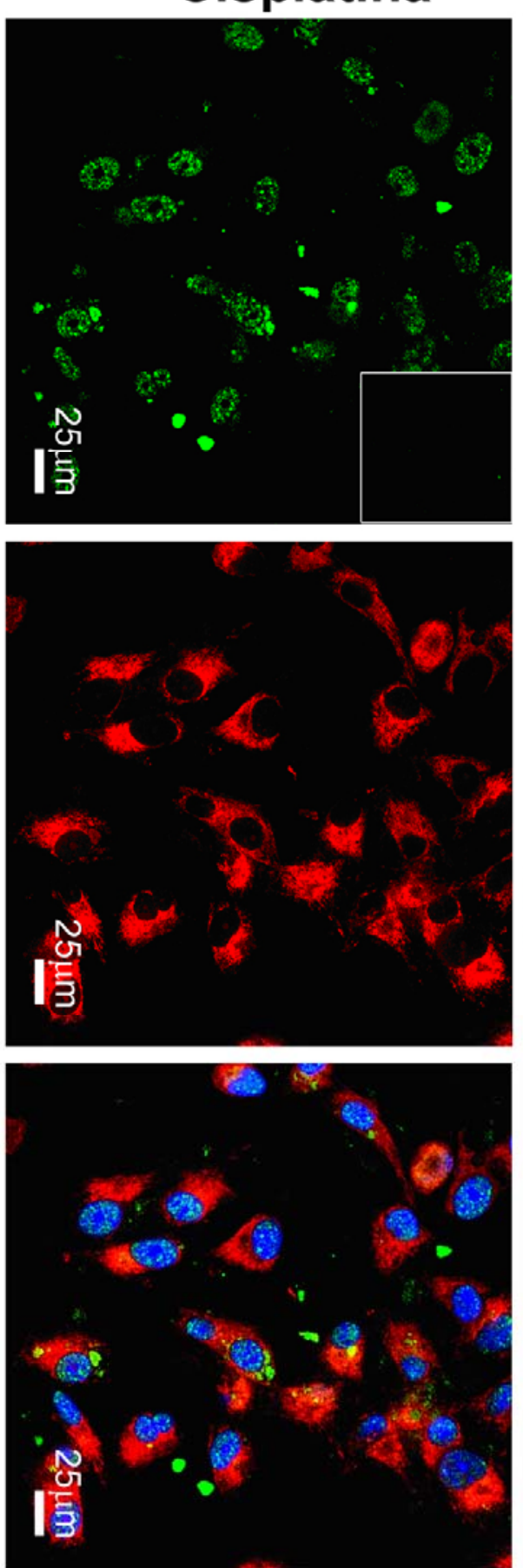

LB373

Controle
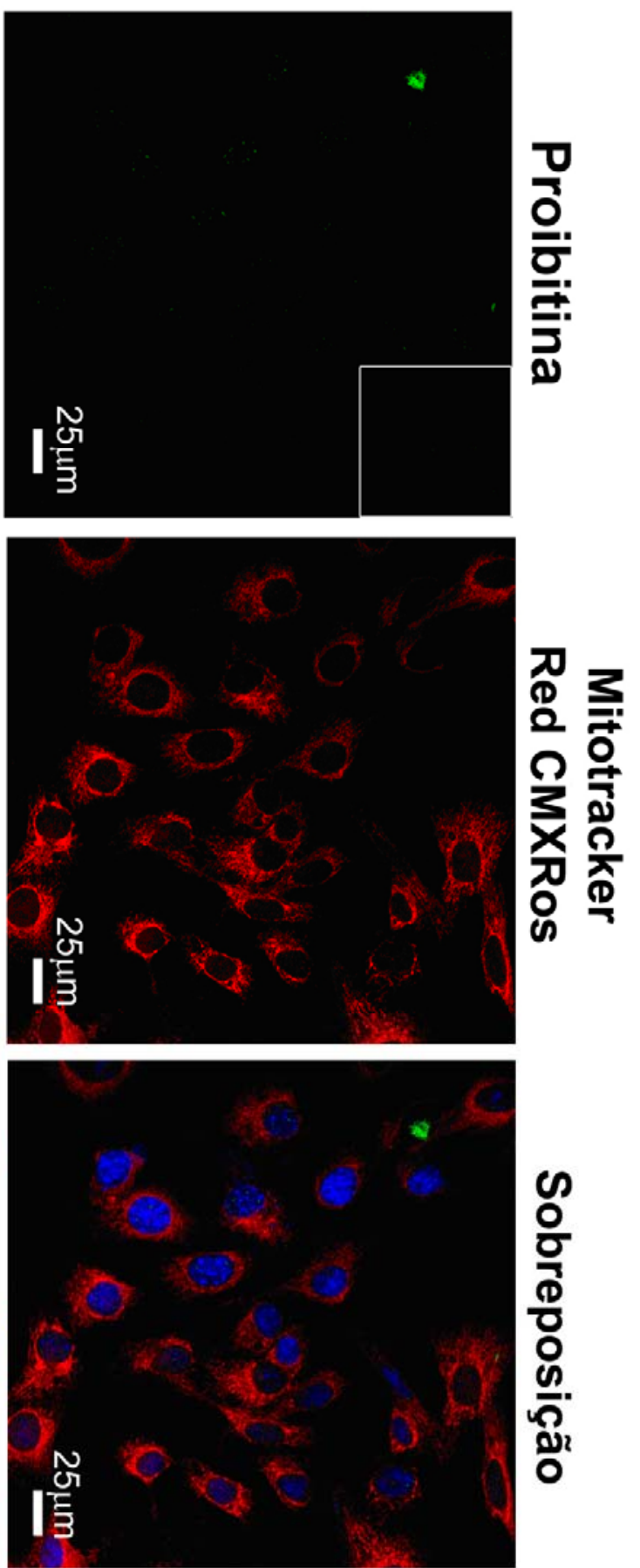

Figura 18. Microscopia confocal da linhagem LB373Mel na presença ou ausência de tratamento com cisplatina, utilizando-se anticorpo monoclonal contra proibitina. Proibitina em verde, Mitotracker Red CMXRos ${ }^{\circledR}$ em vermelho e DAPI em Azul. Sobreposição: junção das micrografias representando a marcação com anticorpo anti-proibitina e Mitotracker Red CMXRos ${ }^{\circledR}$. Controle negativo dentro da moldura branca. A barra branca representa $25 \mu \mathrm{M}$. 
SKMel37

Cisplatina
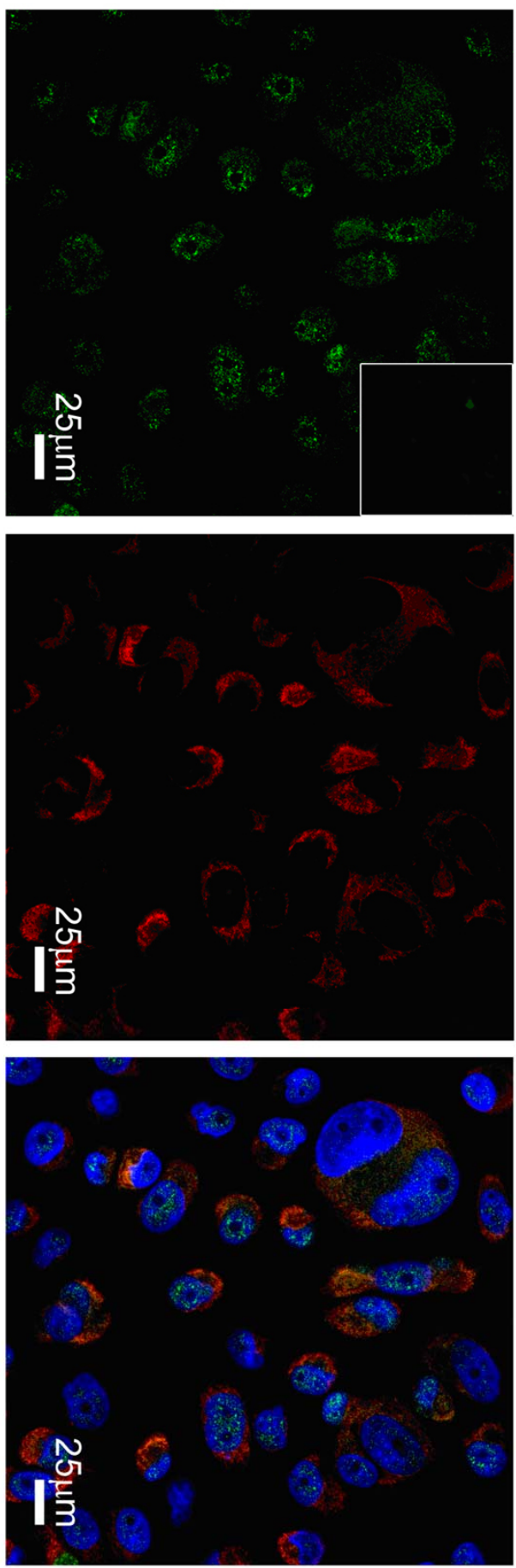

SKMel37 Controle
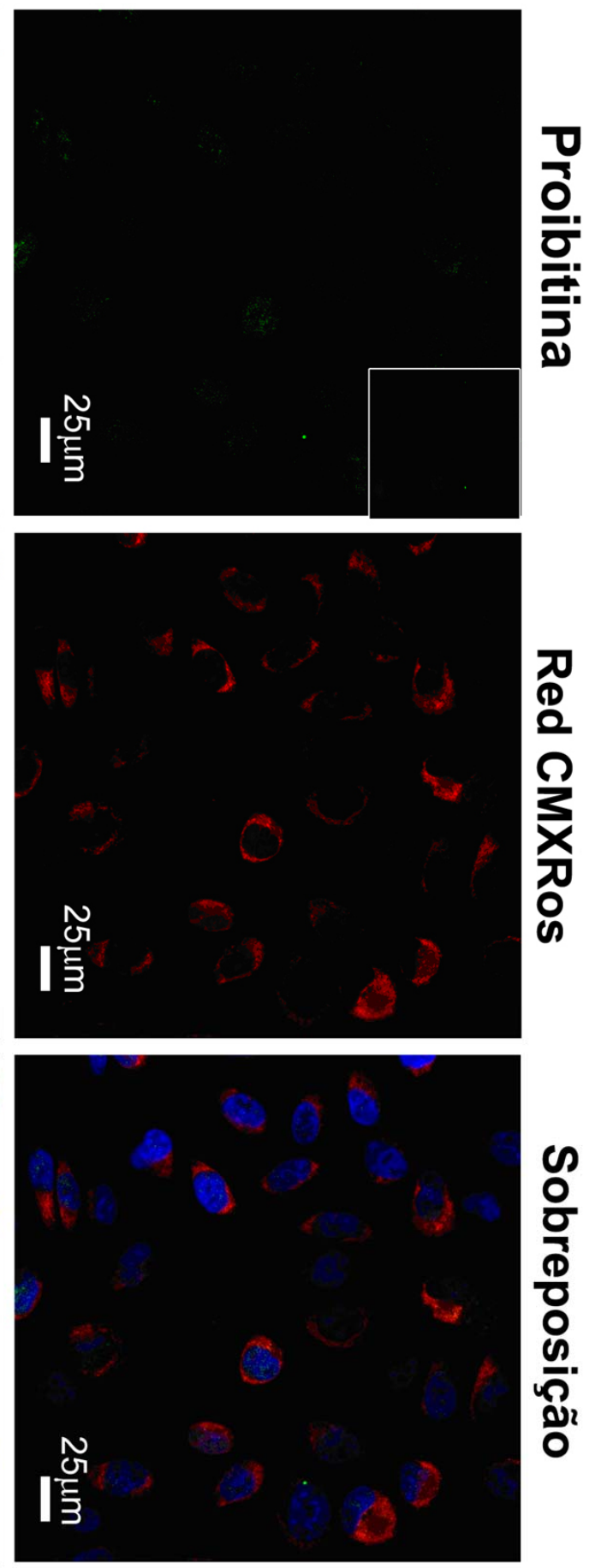

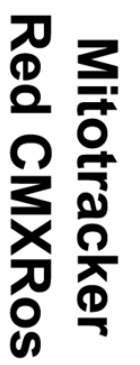

Figura 19. Microscopia confocal da linhagem SKMel 37 na presença ou ausência de tratamento com cisplatina, utilizando-se anticorpo monoclonal contra proibitina. Proibitina em verde, Mitotracker Red CMXRos ${ }^{\circledR}$ em vermelho e DAPI em Azul. Sobreposição: junção das micrografias representando a marcação com anticorpo anti-proibitina e Mitotracker Red CMXRos ${ }^{\circledR}$. Controle negativo dentro da moldura branca. A barra branca representa $25 \mu \mathrm{M}$. 


\section{Mel 85 \\ Cisplatina}
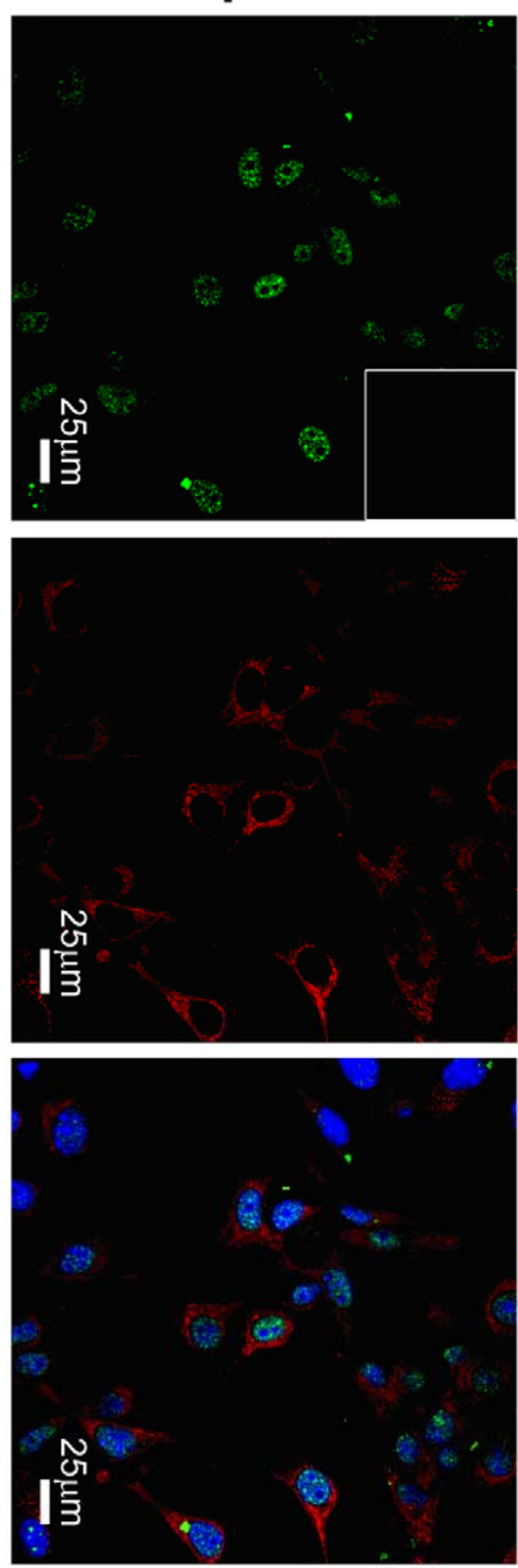

Mel 85

Controle
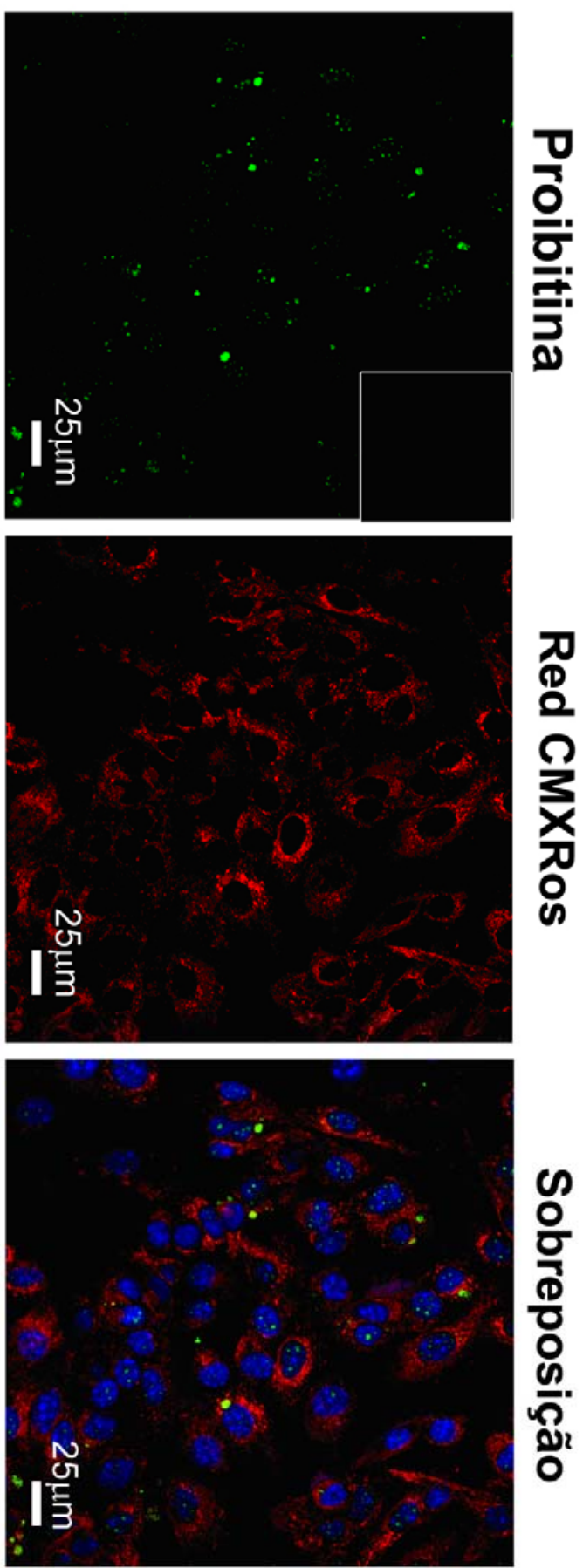

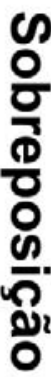

Figura 20. Microscopia confocal da linhagem Mel 85 na presença ou ausência de tratamento com cisplatina, utilizando-se anticorpo monoclonal contra proibitina. Proibitina em verde, Mitotracker Red CMXRos ${ }^{\mathbb{R}}$ em vermelho e DAPI em Azul. Sobreposição: junção das micrografias representando a marcação com anticorpo anti-proibitina e Mitotracker Red CMXRos ${ }^{\circledR}$. Controle negativo dentro da moldura branca. A barra branca representa $25 \mu \mathrm{M}$. 
A proibitina mostrou um padrão diferente de localização nas linhagens LB373Mel, SKMel 37 e Mel 85, ao ser marcada com um anticorpo monoclonal. A microscopia confocal mostrou a proibitina localizada no núcleo após tratamento com cisplatina, diferentemente do que foi observado com o anticorpo policlonal, onde estava co-localizada com a mitocôndria.

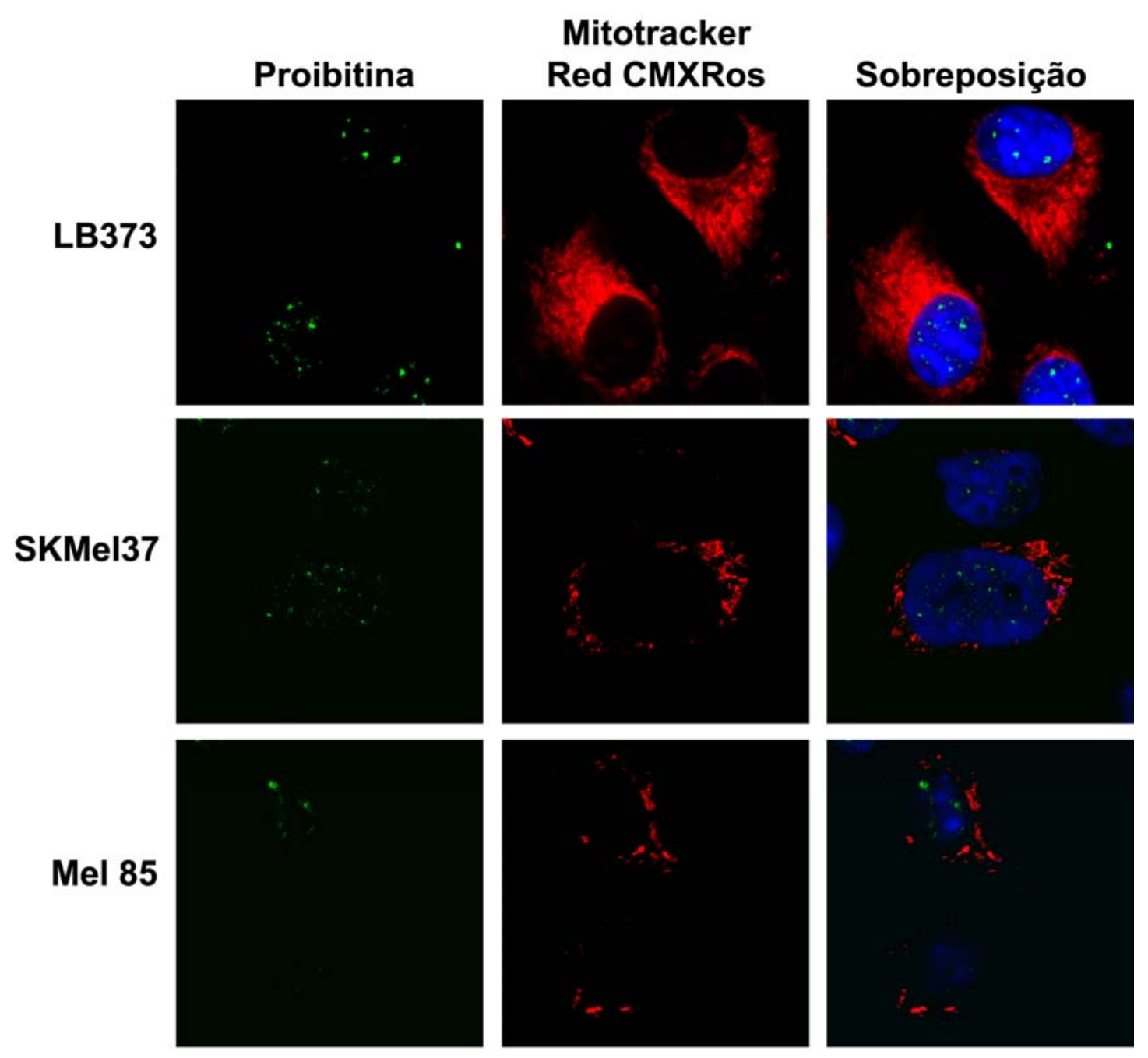

Figura 21. Ampliação de 4x da micrografia das linhagens LB373Mel, SKMel 37 e Mel 85. Proibitina em verde, Mitotracker Red CMXRos ${ }^{\circledR}$ em vermelho e DAPI em Azul. Sobreposição: junção das micrografias representando a marcação com anticorpo anti-proibitina e Mitotracker Red CMXRos ${ }^{\circledR}$. Todas as linhagens foram tratadas com cisplatina. 
A figura 21 mostra, através de uma ampliação de quatro vezes realizada pelo microscópio confocal, que não há evidência de colocalização da proibitina com a mitocôndria ao ser marcada com anticorpo monoclonal. A proibitina (em verde) mostrase co-localizada com a região do marcador de núcleo DAPI. Não há mudança de cor para o alaranjado do marcador de mitocôndria ao se sobrepor as imagens.

As figuras 18 a 21 mostram que a proibitina não está dispersa pelo núcleo. Ela está compartimentalizada em regiões específicas, o que pode ser observado através do padrão pontual apresentado. A fim de se determinar a região onde a proibitina se organiza, tentou-se colocalizar a proibitina com duas proteínas relacionadas com reparo de DNA, histona $\gamma$-H2AX e RAD51. 


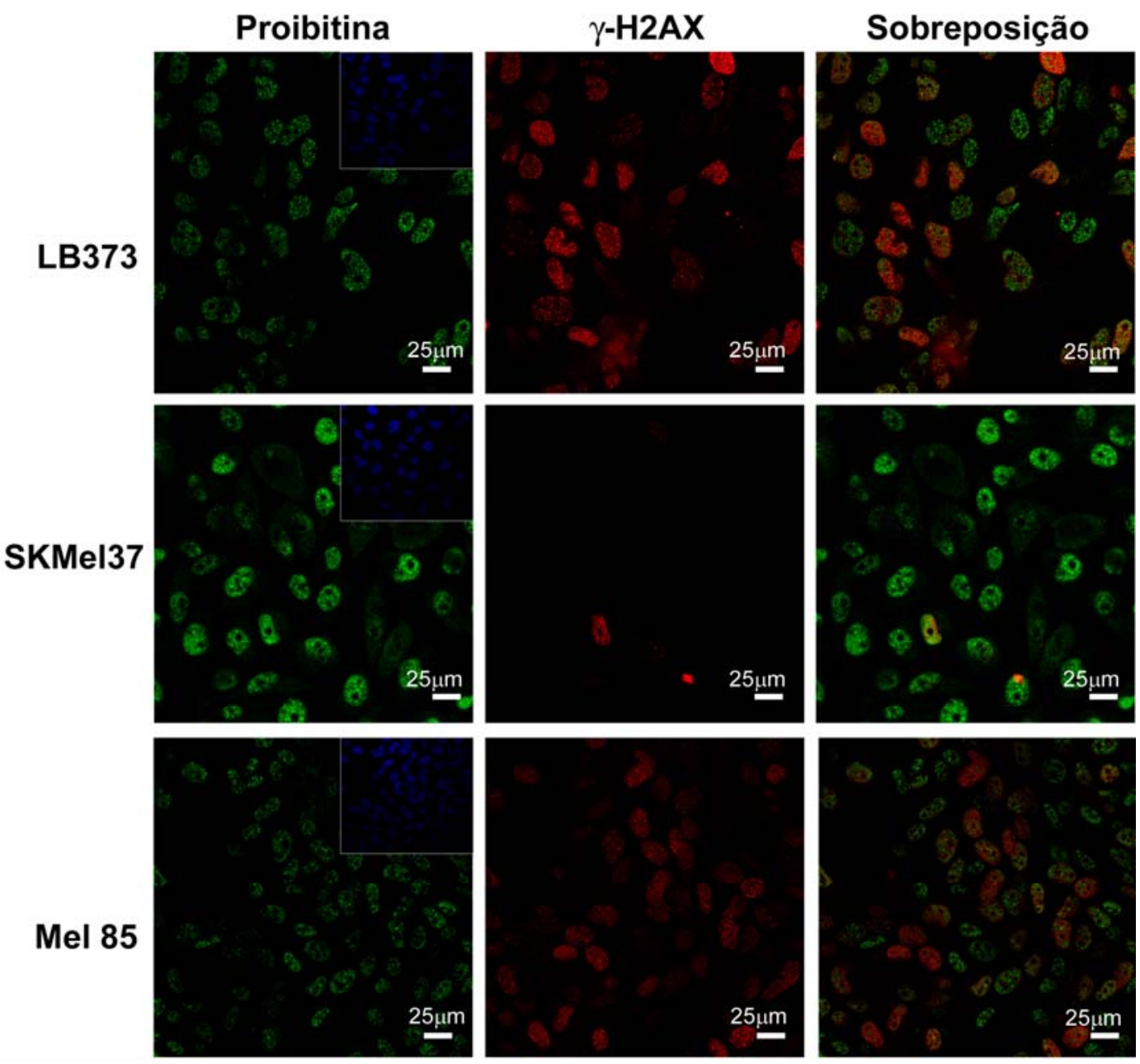

Figura 22. Microscopia confocal da colocalização de proibitina com histona $\gamma$ H2AX nas linhagens LB373Mel, SKMel 37 e Mel 85. Todas as linhagens foram tratadas com $25 \mu \mathrm{M}$ de cisplatina por 24 horas. Proibitina (verde) Histona $\gamma$-H2AX (vermelho) e na moldura, o marcador nuclear DAPI (azul). A barra branca representa $25 \mu \mathrm{M}$. 


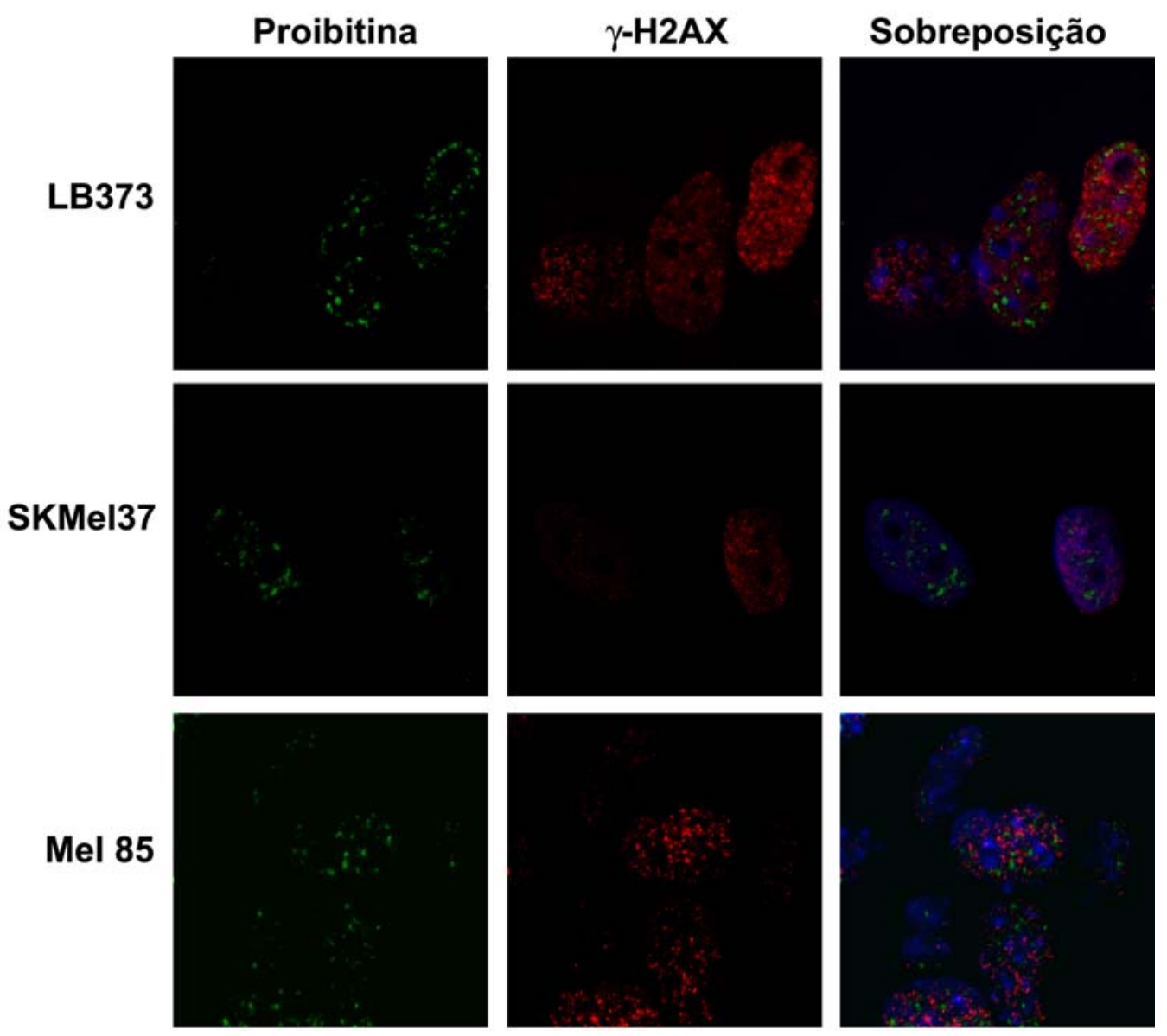

Figura 23. Ampliação da imagem do ensaio de colocalização entre proibitina e histona $\gamma$-H2AX. Todas as linhagens foram tratadas com cisplatina. Proibitina (verde) histona $\gamma$-H2AX (vermelho).

As figuras 22 e 23 mostram que a proibitina não colocaliza com histona $\gamma$-H2AX após 24 horas de tratamento com cisplatina. Como a histona $\gamma-\mathrm{H} 2 \mathrm{AX}$ participa do inicio do processo de reparo, foi feito um experimento com 8 horas de tratamento, para se saber se a colocalização ocorreria no início do processo de reparo de DNA. 
A figura 24 mostrou que não há evidência de colocalização entre proibitina e histona $\gamma$-H2AX nas linhagens LB373Mel e Mel 85 após 8 horas de tratamento com cisplatina. Tentou-se também verificar a colocalização entre proibitina e RAD51, outra proteína associada a reparo de DNA, responsável pelo reparo dos adutos gerados pela cisplatina.

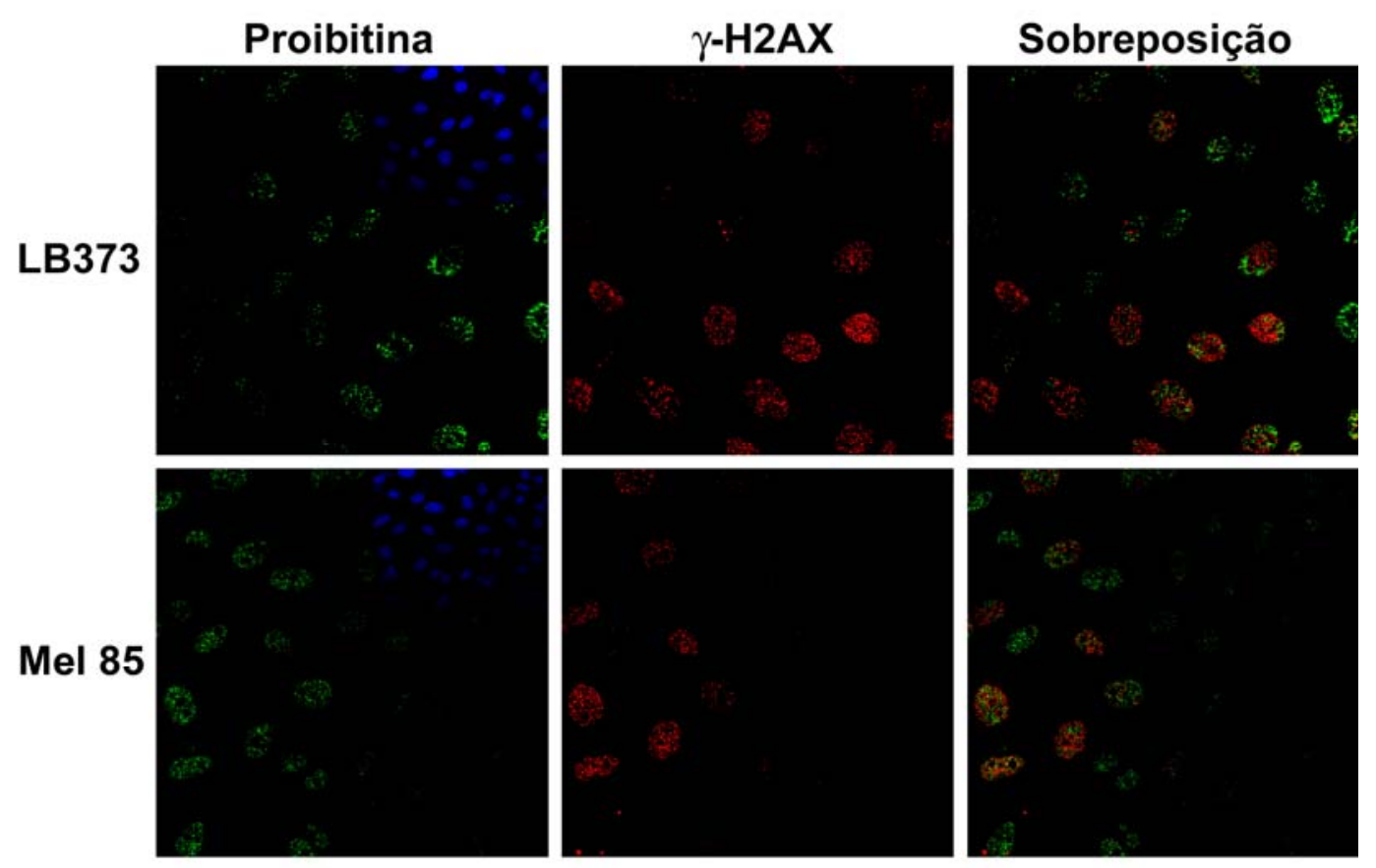

Figura 24. Colocalização entre proibitina e histona $\gamma$-H2AX após 8 horas de tratamento com cisplatina nas linhagens LB373Mel e Mel 85. Proibitina (verde), histona $\gamma$-H2AX (vermelho) e DAPI (azul). 


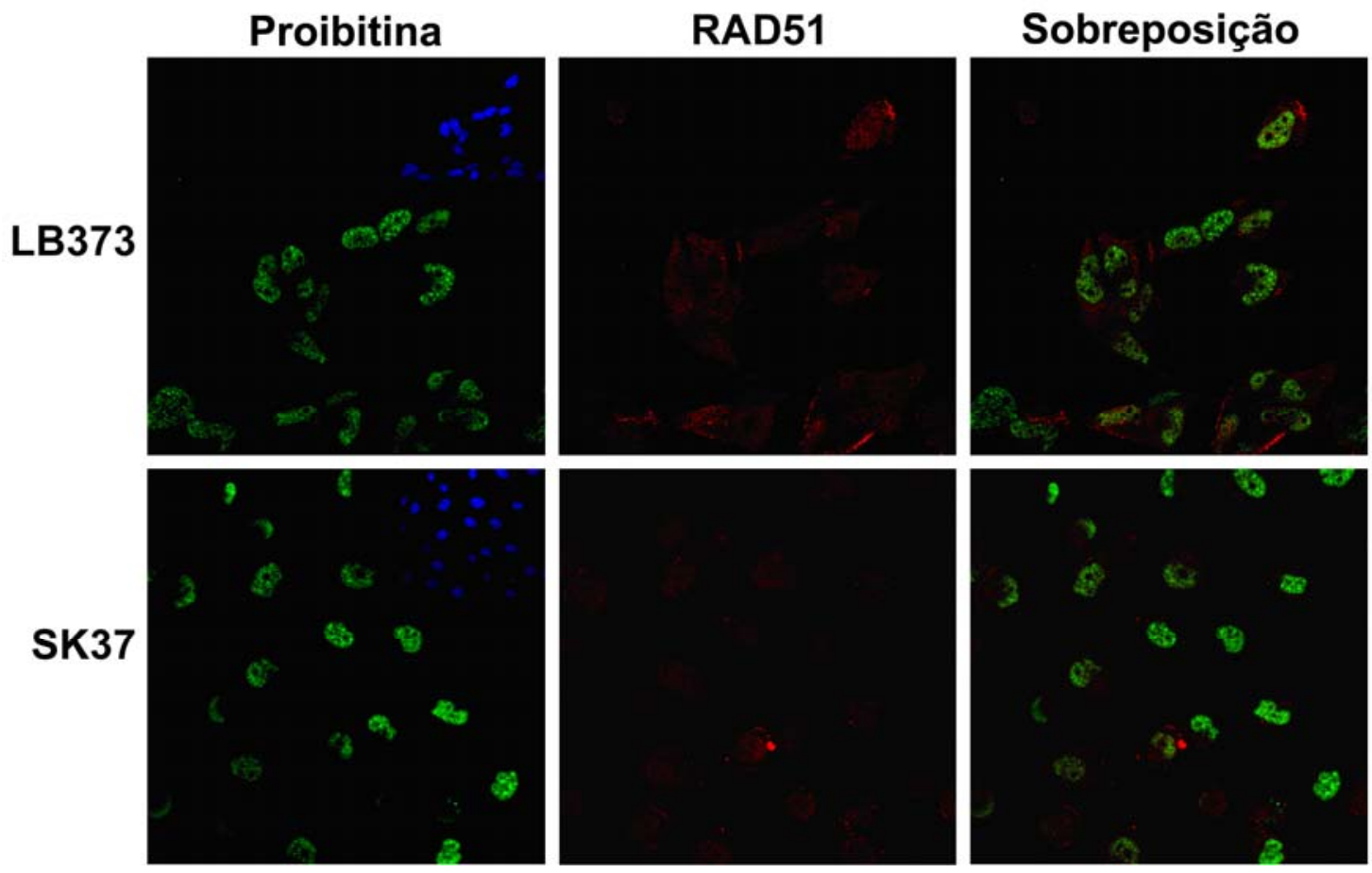

Figura 25. Colocalização entre proibitina e RAD51 após tratamento com cisplatina nas linhagens LB373Mel e SKMel 37. Proibitina (verde), RAD51 (vermelho) e DAPI (azul).

A figura 25 mostra que não houve colocalização entre proibitina e RAD51 nas linhagens LB373Mel e SKMel 37 após tratamento com cisplatina. Vale notar que houve uma marcação de RAD51 no citoplasma, que pode ter ocorrido por deficiência na técnica ou por esta proteína estar se acumulando no citoplasma, pelo menos nessas duas linhagens de melanoma metastático humano. Isso pode ter mascarado uma possível colocalização entre as duas proteínas. 


\subsection{Avaliação da subexpressão de Proibitina}

Para verificar se o aumento da expressão de proibitina após tratamento com cisplatina está induzindo a célula à morte ou se serve como uma forma de proteção, foi utilizado a técnica de RNA de interferência para ver o efeito de sua inibição em prol da morte ou sobrevivência celular.

(a)

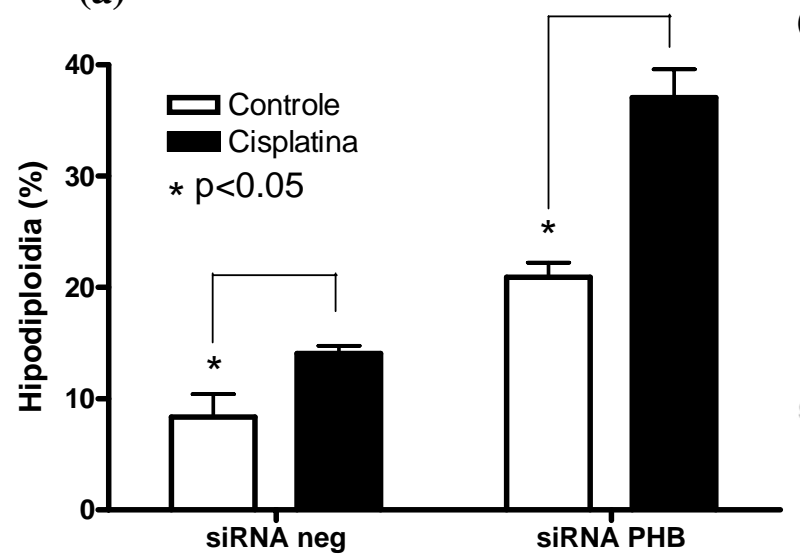

(b)

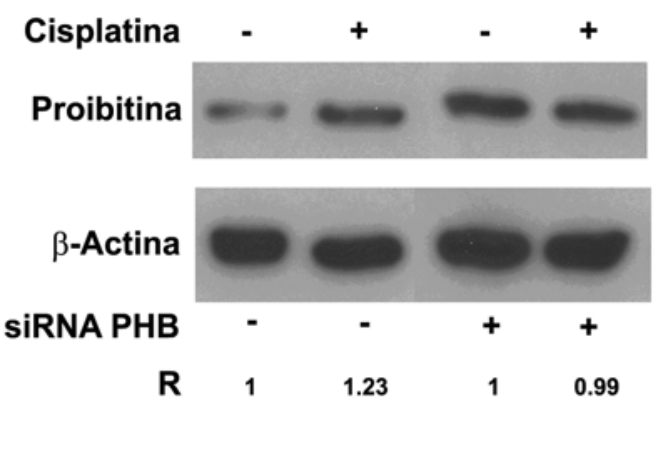

Figura 26. (a) Quantidade de células hipodiplóides na linhagem LB373Mel na presença ou não de siRNA contra proibitina, com ou sem tratamento com cisplatina. (b) Western blot de proibitina na linhagem LB373 na presença ou não de siRNA contra proibitina, com ou sem tratamento com cisplatina. R: valor relativo da expressão de proibitina comparada dentro de uma mesma linhagem. $\beta$-actina: controle de massa.

A figura 26 mostra o resultado do ensaio de siRNA na linhagem LB373Mel. Nela, é possível observar que a inibição da expressão de proibitina por siRNA sensibilizou a célula à morte, mesmo na ausência de tratamento com cisplatina (fig. 26a). O western blot (fig. 26b) mostrou que após a exposição da célula a cisplatina, houve um aumento de $23 \%$ no nível de expressão de proibitina na ausência de sua inibição. A adição do siRNA contra proibitina não provocou sua inibição completa, mas 
sim, uma incapacidade de sua superexpressão após tratamento com cisplatina, como pode ser visto através do valor de sua expressão relativa $(\mathrm{R})$.

Após esses resultados, verificou-se se a cisplatina têm a capacidade de provocar um aumento de células nas fases S/G2/M após a transfecção do siRNA contra proibitina nas linhagens LB373Mel, SKMel 37 e Mel 85.

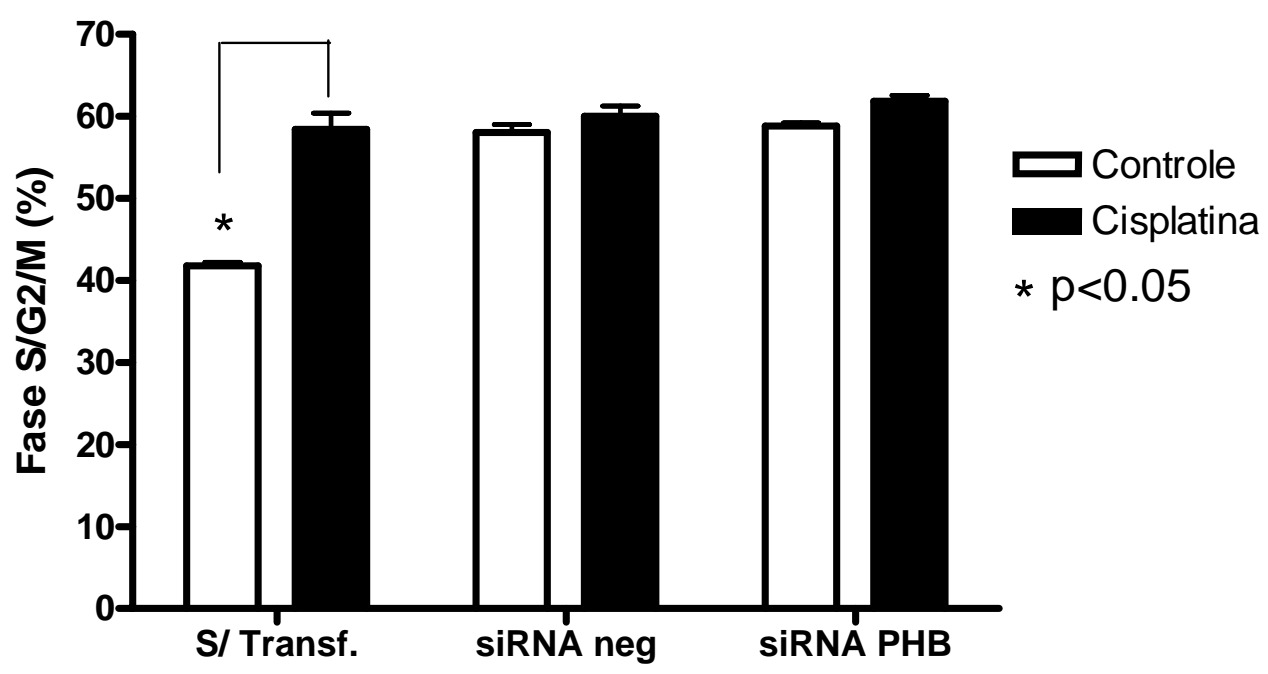

Figura 27. Porcentagem de células na fase S/G2/M na linhagem LB373Mel antes e após tratamento com cisplatina, representando a quantidade total de células viáveis nessas fases do ciclo celular.

A figura 27 mostra o resultado da Análise das fases do ciclo celular da linhagem LB373Mel através de uma região feita nas mesmas condições da figura 12. Após a transfecção tanto do siRNA negativo como a transfecção do siRNA contra proibitina, houve uma incapacidade da linhagem LB373Mel acumular células nas fases S/G2/M do ciclo celular após tratamento com cisplatina, o que não ocorre quando não há transfecção. 
(a)

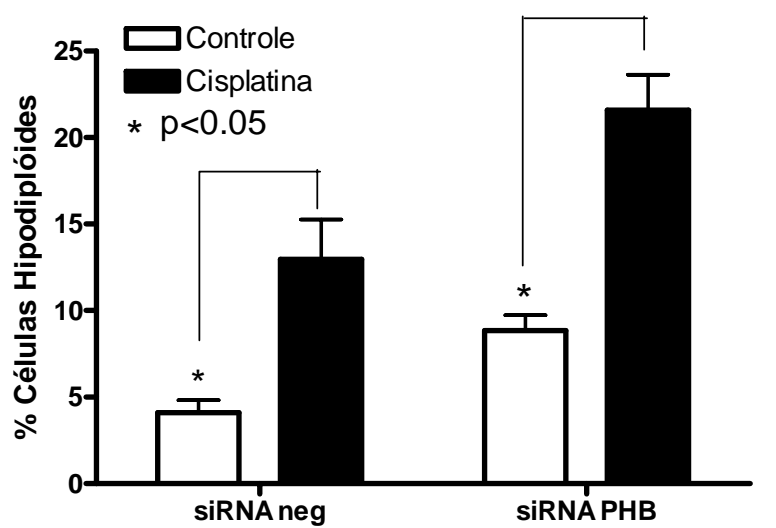

(b)

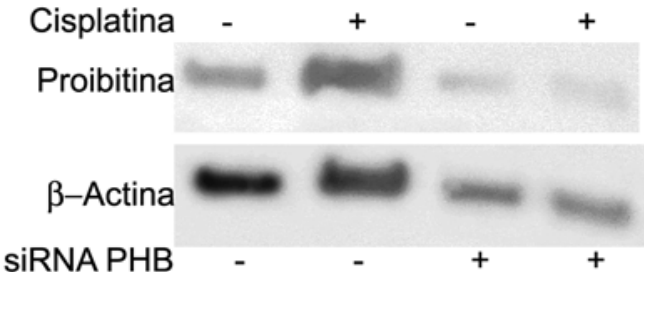

Figura 28. (a) Quantidade de células hipodiplóides na linhagem Mel85 na presença ou não de siRNA contra proibitina, com ou sem tratamento com cisplatina. (b) Western blot de proibitina na linhagem LB373 na presença ou não de siRNA contra proibitina, com ou sem tratamento com cisplatina. R: valor relativo da expressão de proibitina comparada dentro de uma mesma linhagem. $\beta$-actina: controle de massa.

A figura 28 mostra o resultado do ensaio de siRNA contra proibitina na linhagem Mel85. A transfecção do siRNA contra proibitina também provocou sensibilização dessa linhagem à morte, mesmo na ausência de tratamento com cisplatina (fig. 28a). O western blot (fig. 28b) mostrou um comportamento diferente em relação ao western blot da linhagem LB373Mel (fig. 26b). Dessa vez, houve inibição da expressão de proibitina após o tratamento com cisplatina, com diminuição de $9 \%$ de sua expressão em relação ao seu controle transfectado com siRNA contra proibitina, porém sem tratamento com cisplatina. 


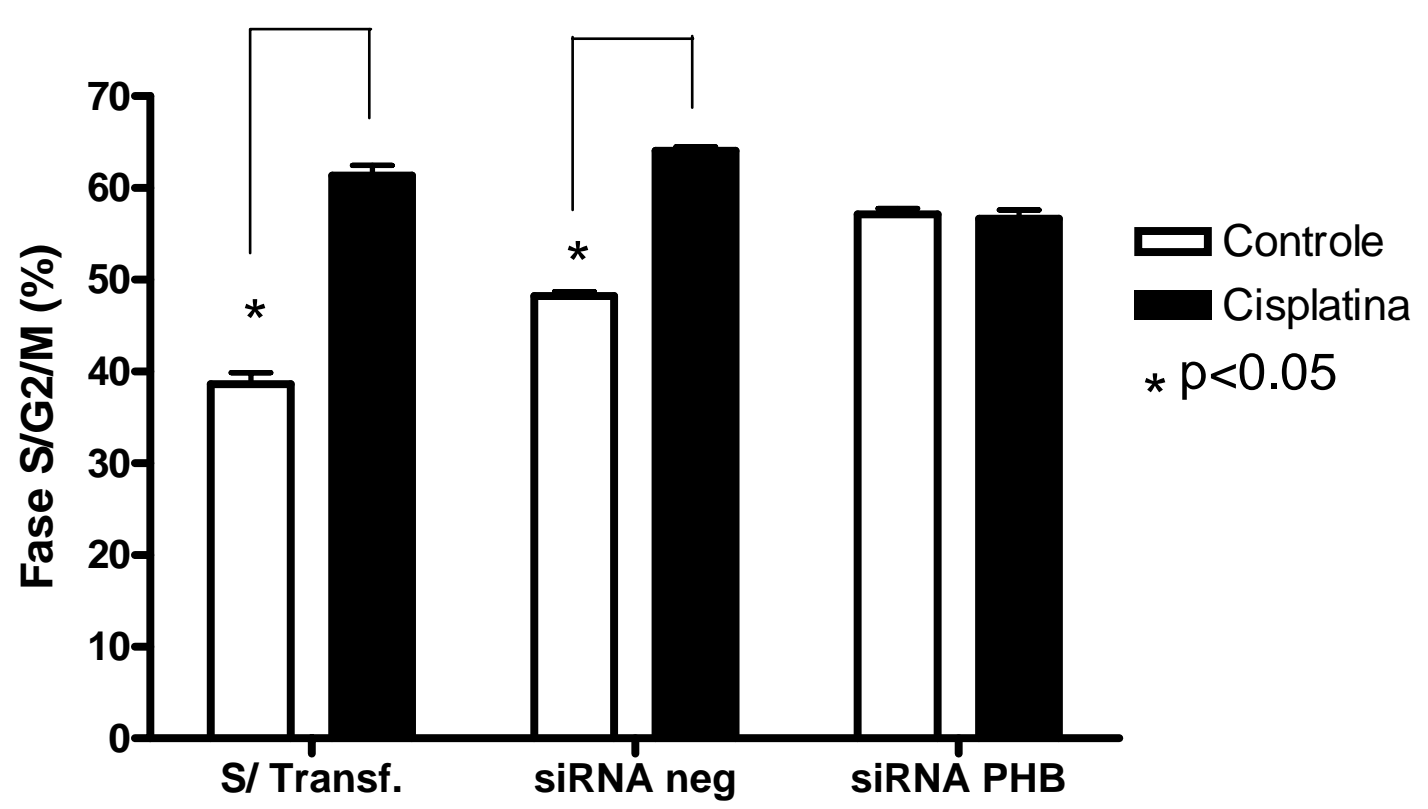

Figura 29. Porcentagem de células na fase $\mathrm{S} / \mathrm{G} 2 / \mathrm{M}$ na linhagem Mel 85 antes e após tratamento com cisplatina, representando a quantidade total de células viáveis nessas fases do ciclo celular.

A figura 29 mostra que, em relação ao grupo transfectado com o siRNA controle, a ausência de proibitina impediu o acúmulo de células nas fases $\mathrm{S} / \mathrm{G} 2 / \mathrm{M}$ do ciclo celular na linhagem Mel85, após tratamento com cisplatina. Esse comportamento foi diferente do observado na linhagem LB373Mel (fig. 27), onde não há diferença em relação ao grupo transfectado com o siRNA controle. 
(a) Controle

* $\mathrm{p}<0.05$

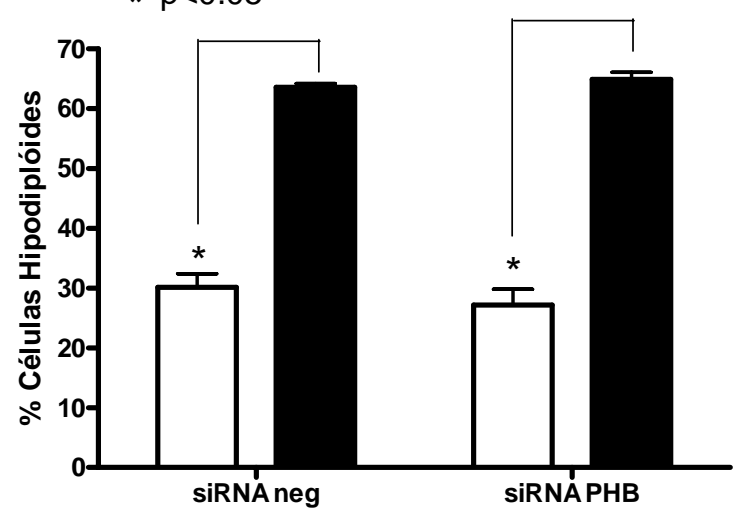

(b)

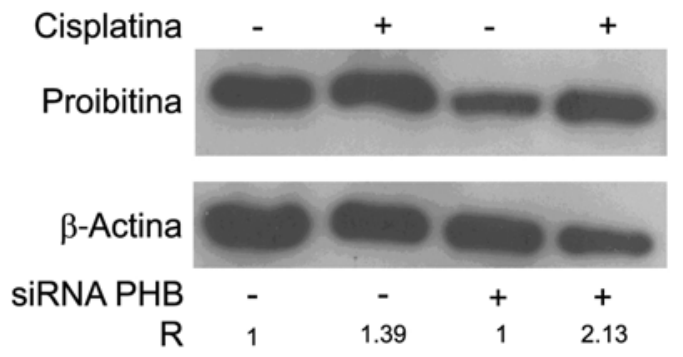

Figura 30. (a) Quantidade de células hipodiplóides na linhagem SKMel 37 na presença ou não de siRNA contra proibitina, com ou sem tratamento com cisplatina. (b) Western blot de proibitina na linhagem LB373 na presença ou não de siRNA contra proibitina, com ou sem tratamento com cisplatina. R: valor relativo da expressão de proibitina comparada dentro de uma mesma linhagem. $\beta$ actina: controle de massa.

A inibição da expressão de proibitina por siRNA na linhagem SKMel 37 não provocou qualquer diferença na capacidade de sua sobrevivência frente à cisplatina. Como pode ser visto na figura 30a, não houve diferença na quantidade de células hipodiplóides após a transfecção do siRNA contra proibitina, mesmo na presença de cisplatina, em relação ao controle transfectado com o siRNA controle. O western blot (fig. 30b) mostrou que houve um aumento na expressão de proibitina após tratamento com cisplatina tanto no grupo transfectado com siRNA controle como no grupo transfectado com siRNA contra proibitina, sendo o aumento no grupo transfectado com siRNA contra proibitina muito mais intenso do que o observado no grupo onde houve a transfecção com o siRNA controle. 


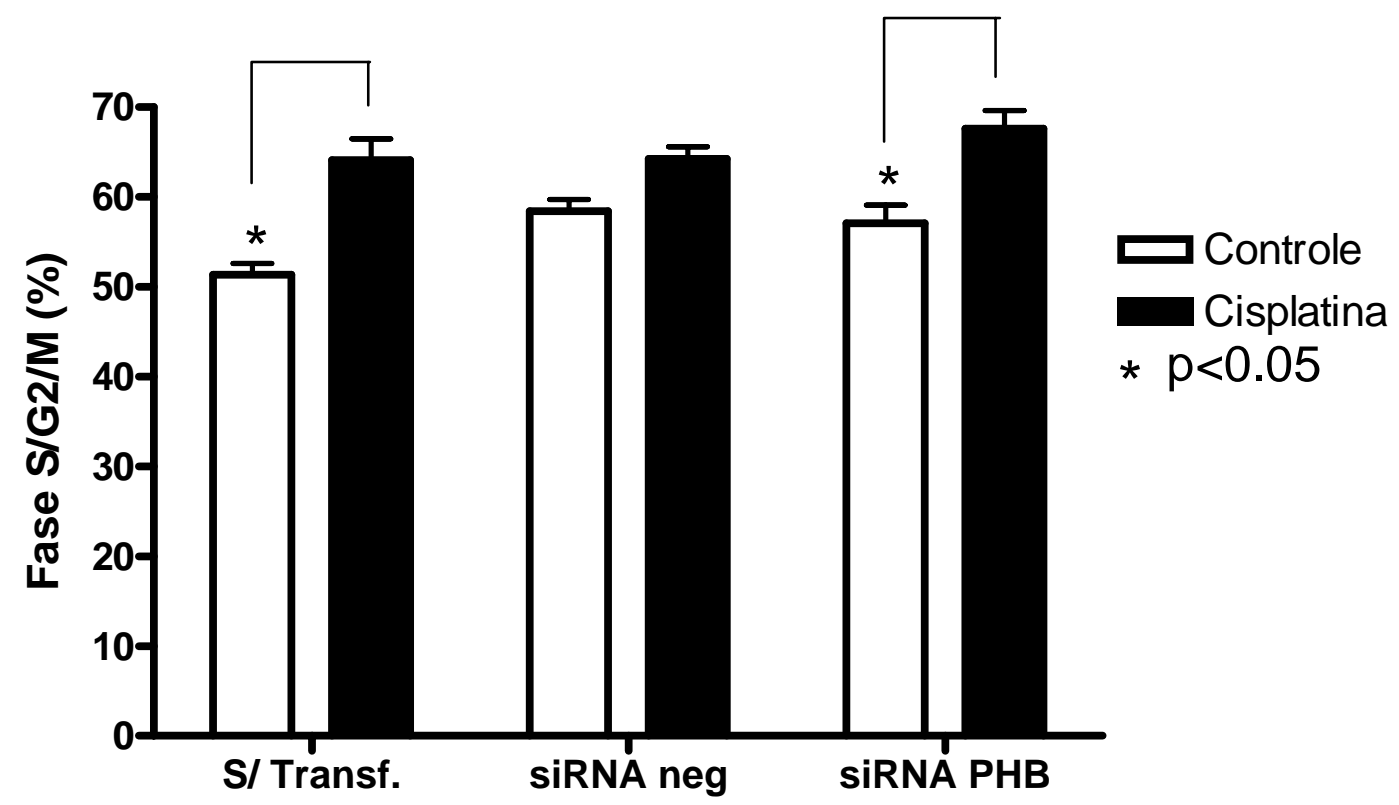

Figura 31. Porcentagem de células na fase S/G2/M na linhagem SKMel 37 antes e após tratamento com cisplatina, representando a quantidade total de células viáveis nessas fases do ciclo celular.

A figura 31 mostra que a inibição de proibitina por siRNA provocou um comportamento diferente na linhagem SKMel 37 em relação às linhagens LB373Mel (fig. 27) e Mel 85 (fig.29). A presença do siRNA contra proibitina permitiu que houvesse um acúmulo de células nas fases $\mathrm{S} / \mathrm{G} 2 / \mathrm{M}$ do ciclo celular após tratamento com cisplatina, em relação ao grupo transfectado com siRNA controle. Esse efeito foi exatamente o contrário do observado na linhagem Mel 85 (fig.29). 


\section{DISCUSSÃO}

Este projeto foi realizado para tentar entender o papel do acúmulo e da localização celular de proibitina em linhagens de melanoma metastático humano frente ao agravo gerado pela ação de cisplatina. Diversas linhagens de melanoma comportamse de maneira diferente frente ao agravo gerado pela cisplatina, sendo umas mais sensíveis do que as outras, mas de uma maneira geral, todas acabam por morrer após tratamento com cisplatina por 24 horas. Verificou-se um acúmulo na expressão protéica de proibitina após tratamento com cisplatina e esse acúmulo favorece a sobrevivência celular, como mostrado pelos ensaios de siRNA. Houve uma distinção na localização subcelular de proibitina de acordo com o tipo de anticorpo utilizado. No citoplasma a proibitina foi detectada usando-se um anticorpo policlonal e colocalizou-se com a mitocôndria. Usando-se um anticorpo monoclonal, detectou-se proibitina compartimentalizada no núcleo, mostrando que essa proteína apresenta epitopos diferentes em diferentes compartimentos subcelulares.

\subsection{Diferença na sensibilidade frente à cisplatina}

A varredura inicial, usando as linhagens LB373Mel, SKMel 37, MZ2, MeWO e Me185, mostrou que essas linhagens de melanoma metastático respondem diferentemente ao serem tratadas com $25 \mu \mathrm{M}$ de cisplatina por 24 horas (fig. 8). Existe uma clara variação na capacidade de sobrevivência dessas células frente ao tratamento, sendo umas mais ou menos sensíveis que as outras. Ao se analisar estatisticamente todas as linhagens, mostrou-se que a linhagem Mel 85 é a menos sensível, após tratamento com cisplatina, em relação às outras linhagens. Do mesmo modo, a linhagem 
SKMel 37 é a mais sensível ao tratamento com cisplatina. O gráfico mostra ainda que a linhagem MZ2 possui uma instabilidade natural, pois mesmo sem tratamento com cisplatina, há um grande número de células já em hipodiploidia.

Shapiro e Harper (1999) mostraram que a ação da cisplatina pode levar a um acúmulo de células nas fases G2/M do ciclo celular. As linhagens analisadas, de uma maneira geral, mostraram esse comportamento após tratamento com cisplatina. Para se demonstrar o acúmulo em G2/M, foi utilizada uma região na análise das populações obtidas pelo citômetro de fluxo, onde apenas células viáveis foram consideradas. O resultado pode ser visto na figura 11, onde apenas a linhagem MZ2 não apresentou um acúmulo em $\mathrm{S} / \mathrm{G} 2 / \mathrm{M}$. Todas as outras linhagens aumentaram a quantidade de células nessas fases do ciclo celular após tratamento com cisplatina.

Os ensaios preliminares das linhagens LB373Mel, SKMel 37, Mel 85, MeWO e MZ2 frente à cisplatina mostraram que essas células respondem com algumas diferenças em termos de sensibilidade ao quimioterápico. Isso é um exemplo de que essas linhagens não só passaram por processos de seleção diferente, provavelmente antes de serem retiradas de seus respectivos pacientes, mas também respondem ao agravo gerado pela cisplatina graças a mecanismos biológicos que podem ser mais ou menos eficientes em cada linhagem. É necessário, então, entender como essas linhagens sobrevivem ao tratamento com cisplatina. 


\subsection{Proibitina}

Uma maneira de como as linhagens de melanoma metastático humano estudadas podem sobreviver frente à cisplatina, seja pelos adutos formados no DNA (Eastman, 1987) ou pela produção de radicais livres na mitocôndria (Martins et al. 2008), é através da expressão de proteínas relacionadas com a sobrevivência em ambientes com estresse oxidativo (de Souza et al. 2006). Em um estudo proteômico realizado por nosso laboratório verificou-se que a cisplatina induz a expressão de diversas proteínas relacionadas com a sobrevivência de melanomas em ambientes de estresse oxidativo, entre elas, a proibitina.

A figura 12 mostra que há uma clara tendência de aumento da expressão protéica de proibitina após tratamento com cisplatina. Vale ressaltar que os extratos protéicos utilizados são os controles sem transfecção dos ensaios de siRNA. Não há correlação entre a capacidade de a célula aumentar a expressão de proibitina e a capacidade de sobrevivência frente à cisplatina, pois a linhagem SKMel 37, a mais sensível, é a mais capaz de aumentar a expressão de proibitina (48\%) e a linhagem Mel 85 , a menos sensível, aumenta apenas $13 \%$. Essa informação levaria a crer que o aumento da expressão de proibitina serve como um indutor de morte celular e não como um fator de sobrevivência. A dúvida do papel da proibitina em prol da morte ou sobrevivência celular foi tirada após utilizar-se a técnica de siRNA.

\subsubsection{Subexpressão de Proibitina}

Os ensaios de siRNA das linhagens LB373Mel (fig. 26) e Mel 85 (fig. 28) mostraram que ao se inibir a expressão de proibitina, a célula ficou mais sensível à cisplatina, apesar de isso ter ocorrido de maneira distinta nessas linhagens. Esse 
resultado mostra que o aumento de expressão de proibitina favorece a sobrevivência celular frente ao agravo gerado pela ação da cisplatina.

As linhagens LB373Mel e Mel 85 tornaram-se mais sensíveis à cisplatina após a transfecção do siRNA contra proibitina por mecanismos diferentes. A linhagem LB373Mel perdeu a capacidade de superexpressar proibitina após tratamento com cisplatina, pois na presença de siRNA contra PHB não há aumento de expressão de proibitina após tratamento com cisplatina (fig. 26b). Isso sugere que na condição experimental utilizada, é a proibitina recém-formada no momento do dano citológico causado pela cisplatina a responsável pela sobrevivência celular, ou seja, é a proibitina formada de novo. Apesar de o ensaio ocorrer nas mesmas condições para todas as linhagens, observou-se uma pequena inibição na expressão de proibitina na linhagem Mel 85 (fig. 28b). Ainda assim, é possível observar-se que há expressão de proibitina após tratamento com cisplatina nessa linhagem e, provavelmente, a sensibilização à cisplatina induzida pelo tratamento com siRNA deva-se à incapacidade do acúmulo protéico de proibitina após tratamento com cisplatina. O efeito final nas linhagens LB373Mel e Mel 85 foi o de sensibilizar essas duas linhagens frente à cisplatina.

Mesmo sem haver tratamento com cisplatina, há uma clara sensibilização das linhagens LB373Mel e Mel 85 à morte apenas ao serem transfectadas com siRNA contra proibitina. A falta de proibitina pode estar provocando uma desestabilização na mitocôndria, o que poderia estar levando a célula à morte. Esse efeito pode ser comparado aos achados de (Schleicher et al. 2008) e (Kasashima et al. 2008), onde a proibitina é importante na estabilização da célula endotelial, através da manutenção da estabilidade mitocondrial, permitindo a formação de túbulos. Essa desestabilização poderia também facilitar a liberação de citocromo c pela mitocôndria induzida por cisplatina, facilitando o processo apoptótico. 
Um outro contexto em que a proibitina poderia estar contribuindo para a sobrevivência celular é o contexto de estresse oxidativo. Melanomas são tumores bem adaptados a ambientes com alta produção de espécie reativas de oxigênio. O papel de chaperona mitocondrial (Nijtmans et al. 2000) que o complexo PHB-PHB2 exerce na membrana interna da mitocôndria poderia corrigir o enovelamento errado de proteínas causado por espécies reativas de oxigênio nesta organela. Esse contexto poderia estar relacionado com uma das principais vias ativadas com o desenvolvimento de melanomas, a via do AKT. Essa via leva a ativação de genes responsáveis pela transformação de melanoma de crescimento radial em vertical, permitindo a invasão da derme adjacente (Govindarajan et al. 2003). Como foi mostrado por (Han et al. 2008), a proibitina pode ser fosforilada por AKT, podendo funcionar como um braço de sobrevivência dessa via. Vale ressaltar que AKT pode ser ativado por espécies reativas de oxigênio (Govindarajan et al. 2007). A produção de espécies reativas de oxigênio em melanomas poderia funcionar como um ativador de AKT que poderia usar a proibitina como um fator de sobrevivência à fonte de produção de espécies reativas de oxigênio, no caso a cisplatina, e ativar outras vias, como $\mathrm{NF}-\kappa \mathrm{B}$, levando à produção de VEGF (Govindarajan et al. 2007), permitindo sua sobrevivência.

A linhagem LB373Mel não mostrou alteração na capacidade de acumular células nas fases S/G2/M do ciclo celular como ocorreu quando não há transfecção (fig. 27). A transfecção do siRNA controle pode ter impedido esse acúmulo, o que não era esperado. Com isso, não houve diferença estatística entra a transfecção do siRNA controle e o siRNA contra proibitina.

A linhagem Mel 85, ao contrário da linhagem LB373Mel, apresentou uma diferença em relação ao acúmulo de células nas fases $\mathrm{S} / \mathrm{G} 2 / \mathrm{M}$ do ciclo celular, induzido pela cisplatina. Após a transfecção do siRNA contra proibitina, essa linhagem perdeu a 
capacidade de acumular células nas fases $\mathrm{S} / \mathrm{G} 2 / \mathrm{M}$ do ciclo celular após tratamento com cisplatina (fig. 29). Isso pode ter ocorrido não pela incapacidade da cisplatina bloquear o ciclo celular na ausência de proibitina, mas como a proibitina pode bloquear E2F (Choi et al. 2008), o seu knock-down por siRNA pode ter permitido a passagem da fase G1 para a fase $\mathrm{S}$ do ciclo celular, o que aumentaria a quantidade de células nessa fase, mesmo sem tratamento com cisplatina.

A linhagem SKMel 37 teve um comportamento muito diferente em relação às linhagens LB373Mel e Mel 85. A presença de siRNA contra proibitina não provocou qualquer diferença em relação à sensibilidade dessa linhagem frente ao agravo gerado pela ação da cisplatina. A figura 30a mostra que a sensibilidade à cisplatina é a mesma ao se comparar a transfecção do siRNA controle com o siRNA contra cisplatina.

O western blot (fig. 30b) mostrou que a presença do siRNA contra proibitina provocou um aumento em sua expressão após tratamento com cisplatina. Houve um aumento de $113 \%$ na presença do siRNA contra PHB e de $39 \%$ na presença do siRNA controle. O aumento no nível de expressão de proibitina, na presença do siRNA controle, foi semelhante ao aumento de expressão de proibitina provocado pela ação da cisplatina sem haver qualquer transfecção (fig. 12). Isso mostra que o aumento exacerbado na expressão de proibitina após tratamento com cisplatina na linhagem SKMel 37 foi decorrente da transfecção do siRNA contra proibitina e não da presença do veículo de transfecção (lipofectamina) ou do meio de cultura necessário para a transfecção (Opti-MEM).

A figura 31 mostra que a linhagem SKMel 37 foi capaz de acumular células em S/G2/M mesmo na presença do siRNA contra proibitina, após tratamento com cisplatina. O comportamento da linhagem SKMel 37 é o mesmo ao ser comparada com seu controle sem transfecção, onde também há acúmulo de células em S/G2/M após 
tratamento com cisplatina. Esse comportamento pode ser entendido com o contrario do que aconteceu na linhagem Mel 85. Com o aumento de expressão de proibitina provocado pela transfecção do siRNA contra $\mathrm{PHB}$, pode ter havido um bloqueio da atividade de E2F, diminuindo o número de eventos nas fases $\mathrm{S} / \mathrm{G} 2 / \mathrm{M}$, justificando a diferença estatística observada nessas fases após o tratamento com cisplatina.

Esses resultados mostram que a linhagem SKMel 37 pode ser usada para se comprovar o efeito de proteção que a proibitina confere, pois o seu comportamento foi o oposto das linhagens LB373Mel e Mel 85. Essa linhagem apresentou uma tendência em aumentar a expressão de proibitina após a transfecção com o siRNA contra PHB. Com isso não houve diferença em relação à sensibilidade frente à cisplatina, ao contrário das linhagens LB373Mel e Mel 85, que de uma maneira geral, perderam a capacidade de superexpressar proibitina e tornaram-se mais sensíveis à cisplatina. Além disso, houve acúmulo de células nas fases $\mathrm{S} / \mathrm{G} 2 / \mathrm{M}$ após tratamento com cisplatina em relação aos seus controles sem transfecção ou transfectado com siRNA controle. Na linhagem Mel 85, observou-se que a falta de proibitina associou-se ao acúmulo de células nas fases $\mathrm{S} / \mathrm{G} 2 / \mathrm{M}$

\subsubsection{Localização Subcelular de Proibitina}

A localização da proibitina pôde ser vista de duas maneiras diferentes, de acordo com o anticorpo utilizado. O anticorpo policlonal, da empresa Labvision ${ }^{\circledR}$ mostrou a proibitina no citoplasma (fig. 13, 14 e 15). Ao se utilizar um anticorpo monoclonal, da mesma empresa, sua localização foi observada no núcleo (fig. 18, 19 e 20). Isso sugere que pode haver um epitopo unicamente exposto no núcleo. Um detalhe interessante é que os dois anticorpos são descritos como marcadores mitocondriais em outras 
linhagens. Isso mostra que pode haver diferença na conformação terciária da proibitina em melanomas, já que o anticorpo monoclonal não reconhece sua porção citoplasmática.

Existem duas hipóteses que sustentam essa afirmação. Bouchon et al. mostraram que, em células de melanoma murino $\mathrm{B} 16 \mathrm{~F} 10$, a proibitina pode sofrer uma alquilação em sua porção N-terminal, o que favorece sua compartimentalização nuclear (Bouchon et al. 2007), assim como a proibitina pode ser fosforilada por AKT (Han et al. 2008). A hipótese mais plausível pode ser a fosforilação por AKT, já que AKT é importante para o desenvolvimento do melanoma por sua capacidade de mudar seu padrão de desenvolvimento de crescimento radial para crescimento vertical (Govindarajan et al. 2007). Dados preliminares de nosso laboratório mostram que a inibição de AKT por cerca de duas horas dificulta o acúmulo da proibitina no núcleo, ao ser marcado com o anticorpo monoclonal descrito, e sensibiliza a célula frente à cisplatina. Não se sabe se a proibitina sofre algum tipo de modificação no núcleo em melanoma humano; isso é provável, e será avaliado.

A exposição da proibitina nuclear parece estar relacionada, pelo menos em parte, com a ação da cisplatina. As linhagens LB373Mel e SKMel 37, aparentemente só expressam a fração nuclear de proibitina após tratamento com cisplatina (fig. 18 e 19). A fração nuclear de proibitina pode ser vista na linhagem Mel 85 mesmo sem tratamento com cisplatina, mas sua exposição aumenta com o tratamento. Não se sabe se a proibitina já está localizada no núcleo e sofre alguma modificação após tratamento com cisplatina e passa a ser observada, utilizando-se anticorpo monoclonal, ou se a cisplatina induz o transporte de proibitina para o núcleo. A hipótese mais plausível é a do transporte de proibitina para o núcleo, já que, como mencionado anteriormente, a 
inibição de AKT dificulta o acúmulo de proibitina no núcleo após tratamento com cisplatina.

A compartimentalização nuclear de proibitina pode ser particularmente importante na sobrevivência do melanoma frente ao agravo genotóxico causado pela cisplatina. Xu et al. mostraram que em um modelo de hepatocarcinoma, a proibitina mostra uma disposição preferencialmente citoplasmática (Xu et al. 2008). Isso foi mostrado utilizando-se o mesmo anticorpo monoclonal utilizado nesse estudo. Como a cisplatina induz a formação de espécies reativas de oxigênio, além de provocar a formação de adutos de DNA, a compartimentalização nuclear de proibitina pode estar associada à sobrevivência em ambientes com estresse oxidativo. A sobrevivência celular em ambientes com estresse oxidativo devido à translocação nuclear de proibitina parece ser especifico de melanomas, já que espécies reativas de oxigênio são importantes para a formação de hepatocarcinomas, sendo associado ao aumento da atividade de genes relacionados com a resistência de drogas (Tien and Savaraj, 2006). Além disso, AKT também é importante na formação de hepatocarcinomas (Pang and Poon, 2007), mas não induz a translocação de proibitina para o núcleo, reforçando a hipótese da translocação nuclear de proibitina ser um fator de sobrevivência específico de melanomas.

A linhagem Mel 85 pode ser um exemplo da importância da translocação nuclear de proibitina na sobrevivência de melanomas. Essa linhagem é a menos sensível à ação da cisplatina (fig. 8) e, em relação às linhagens LB373Mel e SKMel 37, é a única linhagem em que a fração nuclear de proibitina pode ser observada mesmo na ausência de cisplatina (fig. 18, 19 e 20). Além disso, a linhagem Mel 85 é a linhagem que apresenta menor taxa de morte espontânea (fig. 8 - barra branca), sendo, possivelmente, a mais estável de todas as linhagens. 
A compartimentalização nuclear de proibitina é descrita como supressor de tumor, devido a sua ação repressora de E2F1 (Wang et al., 2002); (Choi et al., 2008) e por modular positivamente a ação de p53 em modelo de carcinoma mamário humano tratado com camptotecina (Fusaro et al. 2003). De outra forma, talvez a capacidade da proibitina inibir o ciclo celular, através do bloqueio de E2F1, pode funcionar como um fator de seleção, onde a célula teria tempo para que o reparo de DNA ocorra. Isso selecionaria células competentes tornando o tumor resistente à cisplatina. Essa idéia pode ser entendida como um "controle do caos" onde é necessário um estado caótico no DNA para que mutações ocorram e possam ser selecionadas células capazes de sobreviverem ao agravo genotóxico causado pela cisplatina, mas esse estado caótico não pode ser exagerado já que, nesse caso, a célula morreria.

Essa idéia de estabilização genômica pode estar associada à atividade de genes de reparo de DNA. Sarasin e Kauffmann mostraram que apesar das diferenças genéticas entre uma célula metastática e uma célula de um tumor primário, sob alguns aspectos há muito semelhança quanto à expressão de genes de reparo (Sarasin and Kauffmann, 2008). Além disso, a proibitina mantém sua expressão aumentada em metástase de melanoma e que há uma tendência dela compartimentalizar-se no núcleo (R. Salles de Medeiros et al., dados não publicados)

As figuras 18, 19 e 20 mostram que a proibitina não está dispersa no núcleo. Há uma marcação pontual na área marcada com o DAPI, mostrando que a proibitina localiza-se em algum compartimento nuclear. Não há marcação da proibitina na região do nucléolo. Para se tentar determinar essa sublocalização nuclear da proibitina, foram feitos ensaios de colocalização com RAD51 e $\gamma$-H2AX, duas proteínas associadas ao reparo de DNA, baseando-se no trabalho de Sarasin e Kauffmann. 
O ensaio de colocalização entre proibitina e RAD51 nas linhagens LB373Mel e SKMel 37 (fig.25) não obteve sucesso em colocalizar essas duas proteínas. De uma maneira geral, RAD51 mostrou um padrão tipicamente citoplasmático. Isso pode ter uma base biológica ou pode ser um artefato gerado pelo ensaio. De qualquer forma, em algumas células, nas duas linhagens, pode-se observar que quando localizado no núcleo, não há sobreposição de cores entre o verde (proibitina) e o vermelho (RAD51), não havendo sugestão de colocalização entre essas duas proteínas, após tratamento com cisplatina por 24 horas. Pode ser que essa colocalização ocorra em um tempo menor do que 24 horas. Nesse caso, a proibitina funcionaria como um iniciador do processo e logo depois saísse do local de reparo.

Como a cisplatina pode gerar quebra de dupla fita do DNA (Nowosielska and Marinus, 2005) tentou-se colocalizar a proibitina com o marcador de quebra de dupla fita de DNA, Histona $\gamma-\mathrm{H} 2 \mathrm{AX}$. As figuras 22 e 23 mostram que não houve colocalização entre proibitina e histona $\gamma$-H2AX nas linhagens LB373Mel, SKMel 37 e Mel 85 após tratamento com cisplatina por 24 horas. Para se tirar a dúvida da questão temporal, foi feito um ensaio com 8 horas de tratamento com cisplatina nas linhagens LB373Mel e Mel 85 (fig. 24). Não houve também qualquer sugestão de colocalização de proibitina com histona $\gamma$-H2AX com 8 horas de tratamento nessas linhagens.

A proibitina nuclear parece se organizar de forma distinta na linhagem SKMel 37, sugerindo que pode haver uma organização ao redor do nucléolo (fig. 19) o que não ocorre nas linhagens LB373Mel e Mel85, sendo mais dispersa, porém ainda assim compartimentalizada, pelo núcleo (fig. 18 e 20). Essa forma distinta de organização talvez explique a diferença de comportamento observada nos ensaios de siRNA da linhagem SKMel 37 (fig. 30 e 31) em relação às linhagens LB373Mel (fig. 26 e 27) e Mel 85 (fig. 28 e 29). 
A localização citoplasmática da proibitina utilizando-se anticorpo policlonal, nas linhagens de melanomas analisadas, provavelmente confere com o que foi visto na literatura (Nijtmans et al. 2000). Existe uma evidência de colocalização da proibitina citoplasmática com a mitocôndria (fig.13, 14 e 15) que pode ser confirmada através da análise por camadas (z-stack) no microscópio confocal nas linhagens LB373Mel e SKMel 37 e Mel 85 (fig. 17). Nesse tipo de análise, o microscópio confocal consegue segmentar a célula, analisando camadas de aproximadamente $0,5 \mu \mathrm{M}$, mostrando uma proximidade entre a proibitina e a mitocôndria

Essa colocalização reforça o contexto da capacidade de sobrevivência do melanoma em ambiente oxidativo, pois a proibitina está localizada na mitocôndria, permitindo que sua ação de chaperona possa ocorrer. Além disso, sua localização mitocondrial parece ser necessária para a homeostasia celular (Han et al. 2008); (Govindarajan et al. 2007). 


\section{SUMÁRIO DOS RESULTADOS}

1. Cisplatina induz morte celular nas linhagens LB373Mel, SKMel 37, Mel 85, MeWO e MZ2 de melanoma humano;

2. Apenas a linhagem MZ2 não apresentou acúmulo nas fases $S / G 2 / M$ do ciclo celular após tratamento com cisplatina;

3. As linhagens LB373Mel, SKMel 37 e Mel 85 aumentam a expressão de proibitina após tratamento com cisplatina;

4. A linhagem LB373Mel perdeu a capacidade de aumentar o nível de expressão protéica de proibitina e tornou-se mais sensível à cisplatina após a transfecção de siRNA contra proibitina. Além disso, não há diferença na capacidade dessa linhagem acumular células na fase $\mathrm{S} / \mathrm{G} 2 / \mathrm{M}$ do ciclo celular após tratamento com cisplatina na presença de siRNA contra proibitina;

5. A linhagem Mel 85 mostrou uma redução no nível de expressão protéica de proibitina e um aumento de sensibilidade frente à cisplatina após tratamento com siRNA contra cisplatina. O tratamento com siRNA contra proibitina impediu o acúmulo de células nas fases $\mathrm{S} / \mathrm{G} 2 / \mathrm{M}$ do ciclo celular após tratamento com cisplatina;

6. A linhagem SKMel 37 não mostrou um aumento de sensibilidade após tratamento com cisplatina na presença de siRNA contra proibitina. Em compensação, a presença do siRNA contra proibitina provocou um aumento no seu nível de expressão protéica após tratamento com cisplatina e permitiu um acúmulo nas fases $\mathrm{S} / \mathrm{G} 2 / \mathrm{M}$ do ciclo celular;

7. A localização citoplasmática de proibitina é compatível com distribuição mitocondrial, como mostrado pelo anticorpo policlonal; 
8. A localização nuclear de proibitina, mostrada pelo anticorpo monoclonal, revela que há uma organização da proteína no núcleo. Essa diferenciação de compartimentalização da proibitina entre o citoplasma e o núcleo pode estar associada a uma modificação na estrutura terciária da proteína;

9. A proibitina parece estar organizada ao redor do nucléolo na linhagem SKMel 37 ;

10. Não houve colocalização de proibitina com Histona $\gamma$-H2AX e com Rad51. 


\section{CONCLUSÃO}

1- A compartimentalização subcelular de proibitina em linhagens de melanoma humano pode ser observada no citoplasma ou no núcleo, de acordo com o anticorpo utilizado. A compartimentalização citoplasmática de proibitina está associada com a mitocôndria na presença ou ausência de tratamento com cisplatina. A compartimentalização nuclear de proibitina é induzida pelo tratamento com cisplatina. Essa compartimentalização parece ocorrer, pelo menos em parte, pelo transporte de proibitina para o núcleo após tratamento com cisplatina, e pode contribuir para a sobrevivência do melanoma.

2- A subexpressão de proibitina por siRNA leva à sensibilização das linhagens de melanoma LB373Mel e Mel 85 pela cisplatina. O bloqueio da expressão de novo de proibitina parece ser o responsável pela sensibilização dessas linhagens ao tratamento com cisplatina. A linhagem SKMel 37 confirma a importância do aumento de expressão de proibitina para a sobrevivência do melanoma, já que houve aumento da expressão protéica de proibitina mesmo após a transfecção do siRNA e a linhagem não tornou-se mais sensível à cisplatina. 


\section{REFERÊNCIAS BIBLIOGRÁFICAS}

Altaha, R., Liang, X., Yu, J. J., Reed, E. 2004, Excision repair cross complementinggroup 1: gene expression and platinum resistance, Int.J.Mol.Med., 14(6), pp. 959-970.

Artal-Sanz, M., Tsang, W. Y., Willems, E. M., Grivell, L. A., Lemire, B. D., van der, S. H., Nijtmans, L. G. 2003, The mitochondrial prohibitin complex is essential for embryonic viability and germline function in Caenorhabditis elegans, J.Biol.Chem., 278(34), pp. 32091-32099.

Ashkenazi, A., Dixit, V. M. 1999, Apoptosis control by death and decoy receptors, Curr.Opin.Cell Biol., 11(2), pp. 255-260.

Bean, M. A., Bloom, B. R., Herberman, R. B., Old, L. J., Oettgen, H. F., Klein, G., Terry, W. D. 1975, Cell-mediated cytotoxicity for bladder carcinoma: evaluation of a workshop, Cancer Res., 35(10), pp. 2902-2913.

Bellon, S. F., Coleman, J. H., Lippard, S. J. 1991, DNA unwinding produced by sitespecific intrastrand cross-links of the antitumor drug cisdiamminedichloroplatinum(II), Biochem., 30(32), pp. 8026-8035.

Berger, K. H., Yaffe, M. P. 1998, Prohibitin family members interact genetically with mitochondrial inheritance components in Saccharomyces cerevisiae, Mol.Cell Biol., 18(7), pp. 4043-4052.

Bernard, K., Litman, E., Fitzpatrick, J. L., Shellman, Y. G., Argast, G., Polvinen, K., Everett, A. D., Fukasawa, K., Norris, D. A., Ahn, N. G., Resing, K. A. 2003, 
Functional proteomic analysis of melanoma progression, Cancer Res., 63(20), pp. 6716-6725.

Bouchon, B., Papon, J., Communal, Y., Madelmont, J. C., Degoul, F. 2007, Alkylation of prohibitin by cyclohexylphenyl-chloroethyl urea on an aspartyl residue is associated with cell cycle G(1) arrest in B16 cells, Br.J.Pharmacol., 152(4), pp. 449-455.

Bryan, T. M., Cech, T. R. 1999, Telomerase and the maintenance of chromosome ends, Curr.Opin.Cell Biol., 11(3), pp. 318-324.

Carey, T. E., Takahashi, T., Resnick, L. A., Oettgen, H. F., Old, L. J. 1976, Cell surface antigens of human malignant melanoma: mixed hemadsorption assays for humoral immunity to cultured autologous melanoma cells, Proc.Natl.Acad.Sci.U.S.A, 73(9), pp. 3278-3282.

Chaney, S. G., Vaisman, A. 1999, Specificity of platinum-DNA adduct repair, J.Inorg.Biochem., 77(1-2), pp. 71-81.

Chin, L. 2003, The genetics of malignant melanoma: lessons from mouse and man, Nat.Rev.Cancer, 3(8), pp. 559-570.

Choi, D., Lee, S. J., Hong, S., Kim, I. H., Kang, S. 2008, Prohibitin interacts with RNF2 and regulates E2F1 function via dual pathways, Oncogene, 27(12), pp. $1716-1725$.

Chudnovsky, Y., Khavari, P. A., Adams, A. E. 2005, Melanoma genetics and the development of rational therapeutics, J.Clin.Invest, 115(4), pp. 813-824. 
Cullen, K. J., Yang, Z., Schumaker, L., Guo, Z. 2007, Mitochondria as a critical target of the chemotheraputic agent cisplatin in head and neck cancer, J.Bioenerg.Biomembr., 39(1), pp. 43-50.

de Souza, G. A., Godoy, L. M., Teixeira, V. R., Otake, A. H., Sabino, A., Rosa, J. C., Dinarte, A. R., Pinheiro, D. G., Silva, W. A., Jr., Eberlin, M. N., Chammas, R., Greene, L. J. 2006, Proteomic and SAGE profiling of murine melanoma progression indicates the reduction of proteins responsible for ROS degradation, Proteomics, 6(5), pp. 1460-1470.

Del Bello, B., Valentini, M. A., Zunino, F., Comporti, M., Maellaro, E. 2001, Cleavage of Bcl-2 in oxidant- and cisplatin-induced apoptosis of human melanoma cells, Oncogene, 20(33), pp. 4591-4595.

Donahue, B. A., Augot, M., Bellon, S. F., Treiber, D. K., Toney, J. H., Lippard, S. J., Essigmann, J. M. 1990, Characterization of a DNA damage-recognition protein from mammalian cells that binds specifically to intrastrand $d(\mathrm{GpG})$ and $\mathrm{d}(\mathrm{ApG})$ DNA adducts of the anticancer drug cisplatin, Biochem., 29(24), pp. 5872-5880.

Eastman, A. 1987, The formation, isolation and characterization of DNA adducts produced by anticancer platinum complexes, Pharmacol.Ther., 34(2), pp. 155166.

Escargueil, A. E., Soares, D. G., Salvador, M., Larsen, A. K., Henriques, J. A. 2008, What histone code for DNA repair?, Mutat.Res., 658(3), pp. 259-270.

Fink, D., Aebi, S., Howell, S. B. 1998, The role of DNA mismatch repair in drug resistance, Clin.Cancer Res., 4(1), pp. 1-6. 
Fried, L., Arbiser, J. L. 2008, The reactive oxygen-driven tumor: relevance to melanoma, Pigment Cell Melanoma Res., 21(2), pp. 117-122.

Friguet, B., Bulteau, A. L., Petropoulos, I. 2008, Mitochondrial protein quality control: implications in ageing, Biotechnol.J., 3(6), pp. 757-764.

Furuta, T., Ueda, T., Aune, G., Sarasin, A., Kraemer, K. H., Pommier, Y. 2002, Transcription-coupled nucleotide excision repair as a determinant of cisplatin sensitivity of human cells, Cancer Res., 62(17), pp. 4899-4902.

Fusaro, G., Dasgupta, P., Rastogi, S., Joshi, B., Chellappan, S. 2003, Prohibitin induces the transcriptional activity of p53 and is exported from the nucleus upon apoptotic signaling, J.Biol.Chem., 278(48), pp. 47853-47861.

Govindarajan, B., Bai, X., Cohen, C., Zhong, H., Kilroy, S., Louis, G., Moses, M., Arbiser, J. L. 2003, Malignant transformation of melanocytes to melanoma by constitutive activation of mitogen-activated protein kinase kinase (MAPKK) signaling, J.Biol.Chem., 278(11), pp. 9790-9795.

Govindarajan, B., Sligh, J. E., Vincent, B. J., Li, M., Canter, J. A., Nickoloff, B. J., Rodenburg, R. J., Smeitink, J. A., Oberley, L., Zhang, Y., Slingerland, J., Arnold, R. S., Lambeth, J. D., Cohen, C., Hilenski, L., Griendling, K., MartinezDiez, M., Cuezva, J. M., Arbiser, J. L. 2007, Overexpression of Akt converts radial growth melanoma to vertical growth melanoma, J.Clin.Invest, 117(3), pp. 719-729.

Green, D. R., Reed, J. C. 1998, Mitochondria and apoptosis, Science, 281(5381), pp. 1309-1312. 
Han, E. K., Mcgonigal, T., Butler, C., Giranda, V. L., Luo, Y. 2008, Characterization of Akt overexpression in MiaPaCa-2 cells: prohibitin is an Akt substrate both in vitro and in cells, Anticancer Res., 28(2A), pp. 957-963.

Hanahan, D., Folkman, J. 1996, Patterns and emerging mechanisms of the angiogenic switch during tumorigenesis., Cell, 86, pp. 353-364.

Hanahan, D., Weinberg, R. A. 2000, The hallmarks of cancer, Cell, 100(1), pp. 57-70.

Hannay, J. A., Liu, J., Zhu, Q. S., Bolshakov, S. V., Li, L., Pisters, P. W., Lazar, A. J., Yu, D., Pollock, R. E., Lev, D. 2007, Rad51 overexpression contributes to chemoresistance in human soft tissue sarcoma cells: a role for p53/activator protein 2 transcriptional regulation, Mol.Cancer Ther., 6(5), pp. 1650-1660.

Harris, C. C. 1996, p53 tumor suppressor gene: from the basic research laboratory to the clinic--an abridged historical perspective, Carcinogenesis, 17(6), pp. 11871198.

Hawkins, D. S., Demers, G. W., Galloway, D. A. 1996, Inactivation of p53 enhances sensitivity to multiple chemotherapeutic agents, Cancer Res., 56(4), pp. 892898.

Hayflick, L. 1997, Mortality and immortality at the cellular level. A review, Biochemistry (Mosc.), 62(11), pp. 1180-1190.

Herin, M., Lemoine, C., Weynants, P., Vessiere, F., van Pel, A., Knuth, A., Devos, R., Boon, T. 1987, Production of stable cytolytic T-cell clones directed against autologous human melanoma, Int.J.Cancer, 39(3), pp. 390-396. 
Hoye, A. T., Davoren, J. E., Wipf, P., Fink, M. P., Kagan, V. E. 2008, Targeting mitochondria, Acc.Chem.Res., 41(1), pp. 87-97.

Isonishi, S., Saitou, M., Yasuda, M., Tanaka, T. 2001, Mitochondria in platinum resistant cells, Hum.Cell, 14(3), pp. 203-210.

Jacquemont, C., Taniguchi, T. 2007, The Fanconi anemia pathway and ubiquitin, BMC.Biochem., 8 Suppl 1, p. S10.

Kasashima, K., Sumitani, M., Satoh, M., Endo, H. 2008, Human prohibitin 1 maintains the organization and stability of the mitochondrial nucleoids, Exp.Cell Res., 314(5), pp. 988-996.

Kelland, L. R. 1993, New platinum antitumor complexes, Crit Rev.Oncol.Hematol., 15(3), pp. 191-219.

Kelland, L. R. 2000, A new resistance mechanism to cisplatin?, Drug Resist.Updat., 3(3), pp. 139-141.

Kelland, L. R., Mistry, P., Abel, G., Loh, S. Y., O'Neill, C. F., Murrer, B. A., Harrap, K. R. 1992, Mechanism-related circumvention of acquired cisdiamminedichloroplatinum(II) resistance using two pairs of human ovarian carcinoma cell lines by ammine/amine platinum(IV) dicarboxylates, Cancer Res., 52(14), pp. 3857-3864.

Kharbanda, S., Pandey, P., Yamauchi, T., Kumar, S., Kaneki, M., Kumar, V., Bharti, A., Yuan, Z. M., Ghanem, L., Rana, A., Weichselbaum, R., Johnson, G., Kufe, D. 2000, Activation of MEK kinase 1 by the c-Abl protein tyrosine kinase in response to DNA damage, Mol.Cell Biol., 20(14), pp. 4979-4989. 
Klein, H. L. 2008, The consequences of Rad51 overexpression for normal and tumor cells, DNA Repair (Amst), 7(5), pp. 686-693.

Kool, M., de Haas, M., Scheffer, G. L., Scheper, R. J., van Eijk, M. J., Juijn, J. A., Baas, F., Borst, P. 1997, Analysis of expression of cMOAT (MRP2), MRP3, MRP4, and MRP5, homologues of the multidrug resistance-associated protein gene (MRP1), in human cancer cell lines, Cancer Res., 57(16), pp. 3537-3547.

Langhorst, M. F., Reuter, A., Stuermer, C. A. 2005, Scaffolding microdomains and beyond: the function of reggie/flotillin proteins, Cell Mol.Life Sci., 62(19-20), pp. 2228-2240.

Lee, J. M., Dedhar, S., Kalluri, R., Thompson, E. W. 2006, The epithelialmesenchymal transition: new insights in signaling, development, and disease, J.Cell Biol., 172(7), pp. 973-981.

Li, P. F., Dietz, R., von Harsdorf, R. 1999, p53 regulates mitochondrial membrane potential through reactive oxygen species and induces cytochrome cindependent apoptosis blocked by Bcl-2, EMBO J., 18(21), pp. 6027-6036.

Liu, J., Deyoung, S. M., Zhang, M., Dold, L. H., Saltiel, A. R. 2005, The stomatin/prohibitin/flotillin/HflK/C domain of flotillin-1 contains distinct sequences that direct plasma membrane localization and protein interactions in 3T3-L1 adipocytes, J.Biol.Chem., 280(16), pp. 16125-16134.

Liu, Y., Liu, H., Han, B., Zhang, J. T. 2006, Identification of 14-3-3sigma as a contributor to drug resistance in human breast cancer cells using functional proteomic analysis, Cancer Res., 66(6), pp. 3248-3255. 
Lopes, M. T., Sonohara, S., Chammas, R., Brentani, M. M. 1991, Effects of steroids on laminin-binding integrins in a human melanoma cell line, Int.J.Cancer, 48(1), pp. 73-80.

Luo, J., Nikolaev, A. Y., Imai, S., Chen, D., Su, F., Shiloh, A., Guarente, L., Gu, W. 2001, Negative control of p53 by Sir2alpha promotes cell survival under stress, Cell, 107(2), pp. 137-148.

Martins, N. M., Santos, N. A., Curti, C., Bianchi, M. L., Santos, A. C. 2008, Cisplatin induces mitochondrial oxidative stress with resultant energetic metabolism impairment, membrane rigidification and apoptosis in rat liver, J.Appl.Toxicol., 28(3), pp. 337-344.

Nijtmans, L. G., de Jong, L., Artal, S. M., Coates, P. J., Berden, J. A., Back, J. W., Muijsers, A. O., van der, S. H., Grivell, L. A. 2000, Prohibitins act as a membrane-bound chaperone for the stabilization of mitochondrial proteins, EMBO J., 19(11), pp. 2444-2451.

Nowosielska, A., Marinus, M. G. 2005, Cisplatin induces DNA double-strand break formation in Escherichia coli dam mutants, DNA Repair (Amst), 4(7), pp. 773781.

Pang, R. W., Poon, R. T. 2007, From molecular biology to targeted therapies for hepatocellular carcinoma: the future is now, Oncology, 72 Suppl 1, pp. 30-44.

Pastwa, E., Blasiak, J. 2003, Non-homologous DNA end joining, Acta Biochim.Pol., 50(4), pp. 891-908. 
Persons, D. L., Yazlovitskaya, E. M., Pelling, J. C. 2000, Effect of extracellular signalregulated kinase on p53 accumulation in response to cisplatin, J.Biol.Chem., 275(46), pp. 35778-35785.

Pinto, A. L., Lippard, S. J. 1985, Sequence-dependent termination of in vitro DNA synthesis by cis- and trans-diamminedichloroplatinum (II), Proc.Natl.Acad.Sci.U.S.A, 82(14), pp. 4616-4619.

Preston, T. J., Abadi, A., Wilson, L., Singh, G. 2001, Mitochondrial contributions to cancer cell physiology: potential for drug development, Adv.Drug Deliv.Rev., 49(1-2), pp. 45-61.

Rajalingam, K., Wunder, C., Brinkmann, V., Churin, Y., Hekman, M., Sievers, C., Rapp, U. R., Rudel, T. 2005, Prohibitin is required for Ras-induced Raf-MEKERK activation and epithelial cell migration, Nat.Cell Biol., 7(8), pp. 837-843.

Rastogi, S., Joshi, B., Fusaro, G., Chellappan, S. 2006, Camptothecin induces nuclear export of prohibitin preferentially in transformed cells through a CRM-1dependent mechanism, J.Biol.Chem., 281(5), pp. 2951-2959.

Richon, V. M., Schulte, N., Eastman, A. 1987, Multiple mechanisms of resistance to cis-diamminedichloroplatinum(II) in murine leukemia L1210 cells, Cancer Res., 47(8), pp. 2056-2061.

Sarasin, A., Kauffmann, A. 2008, Overexpression of DNA repair genes is associated with metastasis: a new hypothesis, Mutat.Res., 659(1-2), pp. 49-55.

Sarbassov, D. D., Ali, S. M., Kim, D. H., Guertin, D. A., Latek, R. R., ErdjumentBromage, H., Tempst, P., Sabatini, D. M. 2004, Rictor, a novel binding partner 
of mTOR, defines a rapamycin-insensitive and raptor-independent pathway that regulates the cytoskeleton, Curr.Biol., 14(14), pp. 1296-1302.

Sato, T., Saito, H., Swensen, J., Olifant, A., Wood, C., Danner, D., Sakamoto, T., Takita, K., Kasumi, F., Miki, Y., . 1992, The human prohibitin gene located on chromosome 17q21 is mutated in sporadic breast cancer, Cancer Res., 52(6), pp. $1643-1646$.

Schleicher, M., Shepherd, B. R., Suarez, Y., Fernandez-Hernando, C., Yu, J., Pan, Y., Acevedo, L. M., Shadel, G. S., Sessa, W. C. 2008, Prohibitin-1 maintains the angiogenic capacity of endothelial cells by regulating mitochondrial function and senescence, J.Cell Biol., 180(1), pp. 101-112.

Segal-Bendirdjian, E., Mannone, L., Jacquemin-Sablon, A. 1998, Alteration in p53 pathway and defect in apoptosis contribute independently to cisplatin-resistance, Cell Death.Differ., 5(5), pp. 390-400.

Shapiro, G. I., Harper, J. W. 1999, Anticancer drug targets: cell cycle and checkpoint control, J.Clin.Invest, 104(12), pp. 1645-1653.

Sharma, A., Qadri, A. 2004, Vi polysaccharide of Salmonella typhi targets the prohibitin family of molecules in intestinal epithelial cells and suppresses early inflammatory responses, Proc.Natl.Acad.Sci.U.S.A, 101(50), pp. 17492-17497.

Sharma, P., Varma, R., Sarasij, R. C., Ira, Gousset, K., Krishnamoorthy, G., Rao, M., Mayor, S. 2004, Nanoscale organization of multiple GPI-anchored proteins in living cell membranes, Cell, 116(4), pp. 577-589. 
Sharpless, N. E., Kannan, K., Xu, J., Bosenberg, M. W., Chin, L. 2003, Both products of the mouse Ink4a/Arf locus suppress melanoma formation in vivo, Oncogene, 22(32), pp. 5055-5059.

Shi, L., Nishioka, W. K., Th'ng, J., Bradbury, E. M., Litchfield, D. W., Greenberg, A. H. 1994, Premature p34cdc2 activation required for apoptosis, Science, 263(5150), pp. 1143-1145.

Shrivastav, M., De Haro, L. P., Nickoloff, J. A. 2008, Regulation of DNA doublestrand break repair pathway choice, Cell Res., 18(1), pp. 134-147.

Siddik, Z. H. 2003, Cisplatin: mode of cytotoxic action and molecular basis of resistance, Oncogene, 22(47), pp. 7265-7279.

Skobe, M., Fusenig, N. E. 1998, Tumorigenic conversion of immortal human keratinocytes through stromal cell activation, Proc.Natl.Acad.Sci.U.S.A, 95(3), pp. 1050-1055.

Sorenson, C. M., Eastman, A. 1988, Influence of cis-diamminedichloroplatinum(II) on DNA synthesis and cell cycle progression in excision repair proficient and deficient Chinese hamster ovary cells, Cancer Res., 48(23), pp. 6703-6707.

Sporn, M. B. 1996, The war on cancer, Lancet, 347(9012), pp. 1377-1381.

Terashima, M., Kim, K. M., Adachi, T., Nielsen, P. J., Reth, M., Kohler, G., Lamers, M. C. 1994, The IgM antigen receptor of B lymphocytes is associated with prohibitin and a prohibitin-related protein, EMBO J., 13(16), pp. 3782-3792.

Thornberry, N. A., Lazebnik, Y. 1998, Caspases: enemies within, Science, 281(5381), pp. 1312-1316. 
Tien, K. M., Savaraj, N. 2006, Roles of reactive oxygen species in hepatocarcinogenesis and drug resistance gene expression in liver cancers, Mol.Carcinog., 45(9), pp. 701-709.

Ushio-Fukai, M. 2006, Localizing NADPH oxidase-derived ROS, Sci.STKE., 2006(349), p. re8.

Varner, J. A., Cheresh, D. A. 1996, Integrins and cancer, Curr.Opin.Cell Biol., 8(5), pp. 724-730.

Vaziri, H., Dessain, S. K., Ng, E. E., Imai, S. I., Frye, R. A., Pandita, T. K., Guarente, L., Weinberg, R. A. 2001, hSIR2(SIRT1) functions as an NAD-dependent p53 deacetylase, Cell, 107(2), pp. 149-159.

Wang, S., Zhang, B., Faller, D. V. 2002, Prohibitin requires Brg-1 and Brm for the repression of E2F and cell growth, EMBO J., 21(12), pp. 3019-3028.

Weinberg, R. A. 1995, The retinoblastoma protein and cell cycle control, Cell, 81(3), pp. 323-330.

Werb, Z. 1997, ECM and cell surface proteolysis: regulating cellular ecology., Cell, 91, pp. 439-442.

Xu, D. H., Tang, J., Li, Q. F., Shi, S. L., Chen, X. F., Liang, Y. 2008, Positional and expressive alteration of prohibitin during the induced differentiation of human hepatocarcinoma SMMC-7721 cells, World J.Gastroenterol., 14(32), pp. 50085014. 


\section{APÊNDICE}

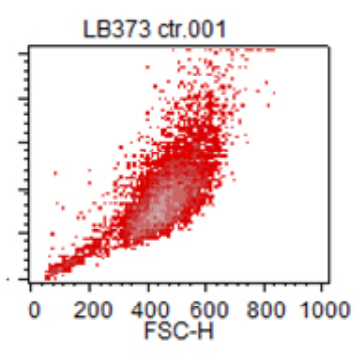

LB373 ctr.001

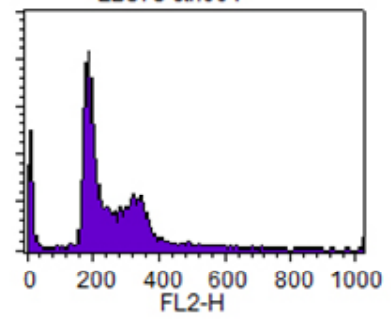

LB373 ctr.002
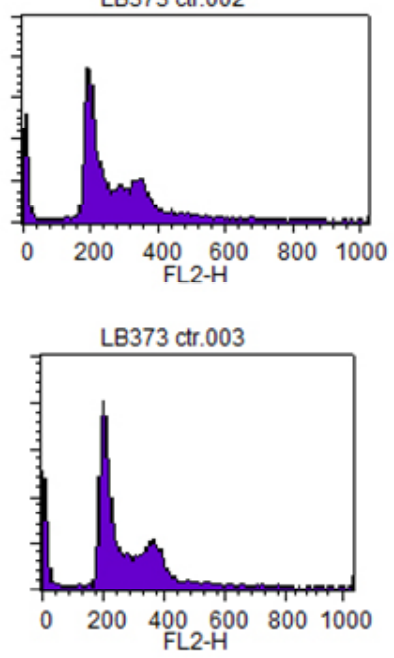

LB373 ctr.001

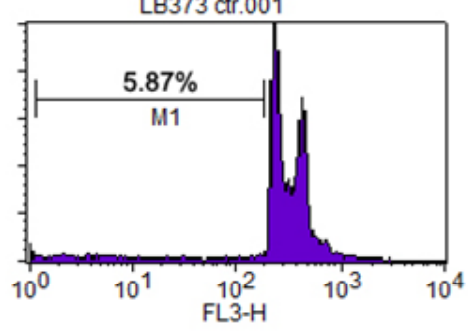

LB373 ctr.002
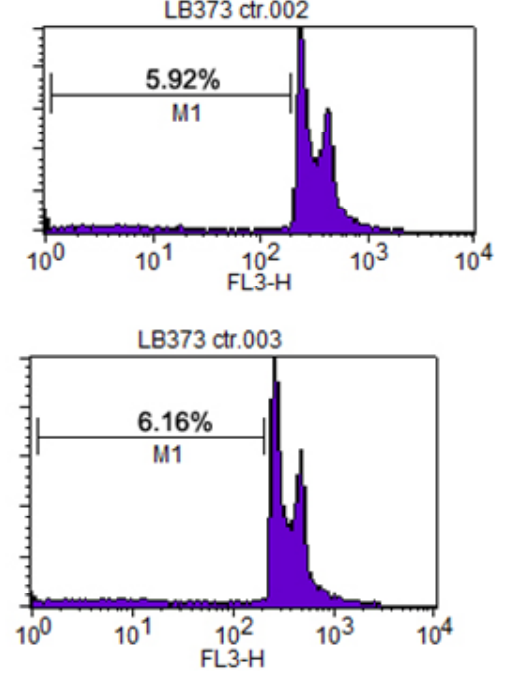

Figura 1. Analise da linhagem LB373Mel por citometria de fluxo na ausência de tratamento com cisplatina. O número representa a porcentagem de eventos analisados pelo FACS na região M1 (hipodiplóide). 

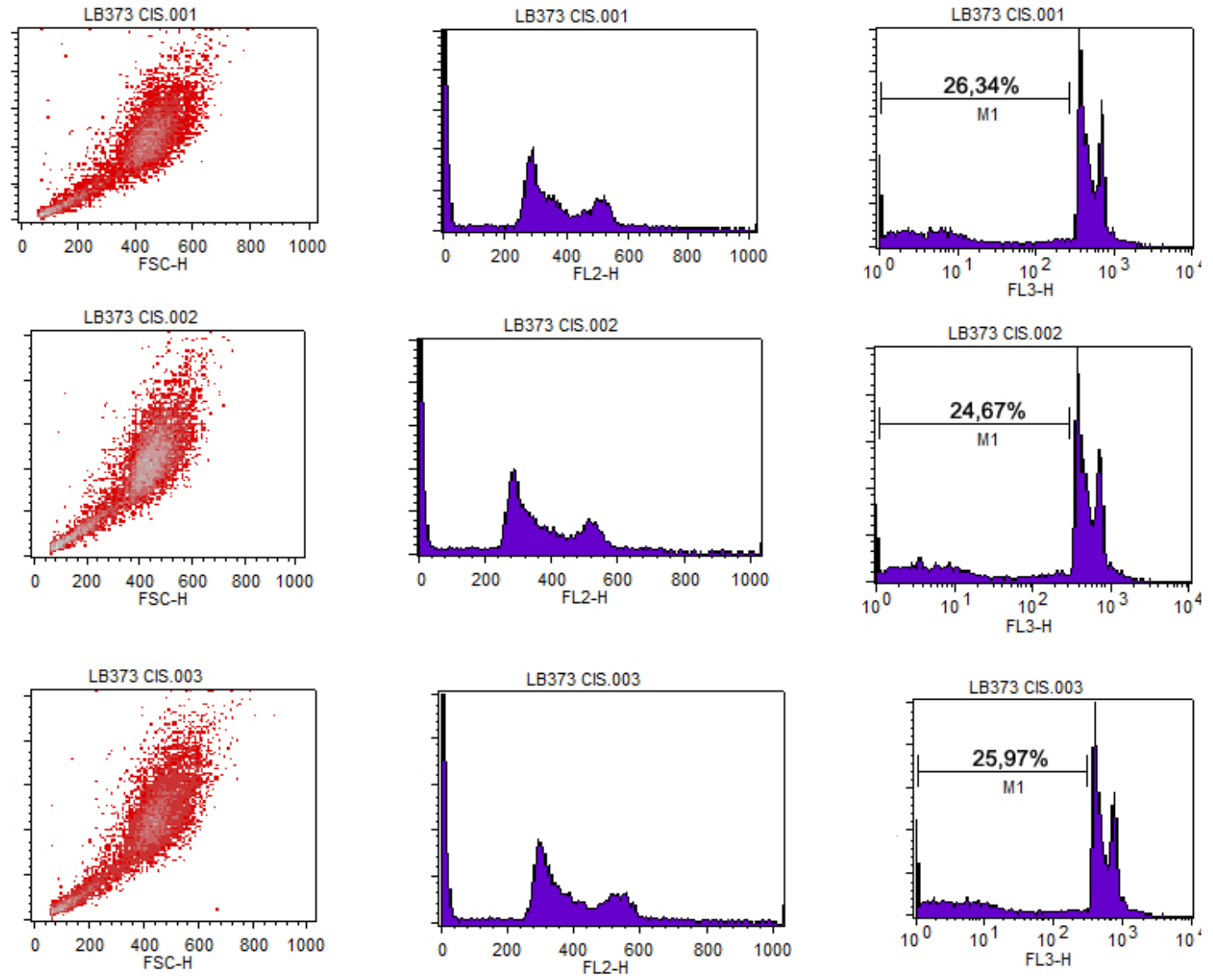

Figura 2. Analise da linhagem LB373Mel por citometria de fluxo após tratamento com $25 \mu \mathrm{M}$ de cisplatina por 24 horas. O número representa a porcentagem de eventos analisados pelo FACS na região M1 (hipodiplóide). 

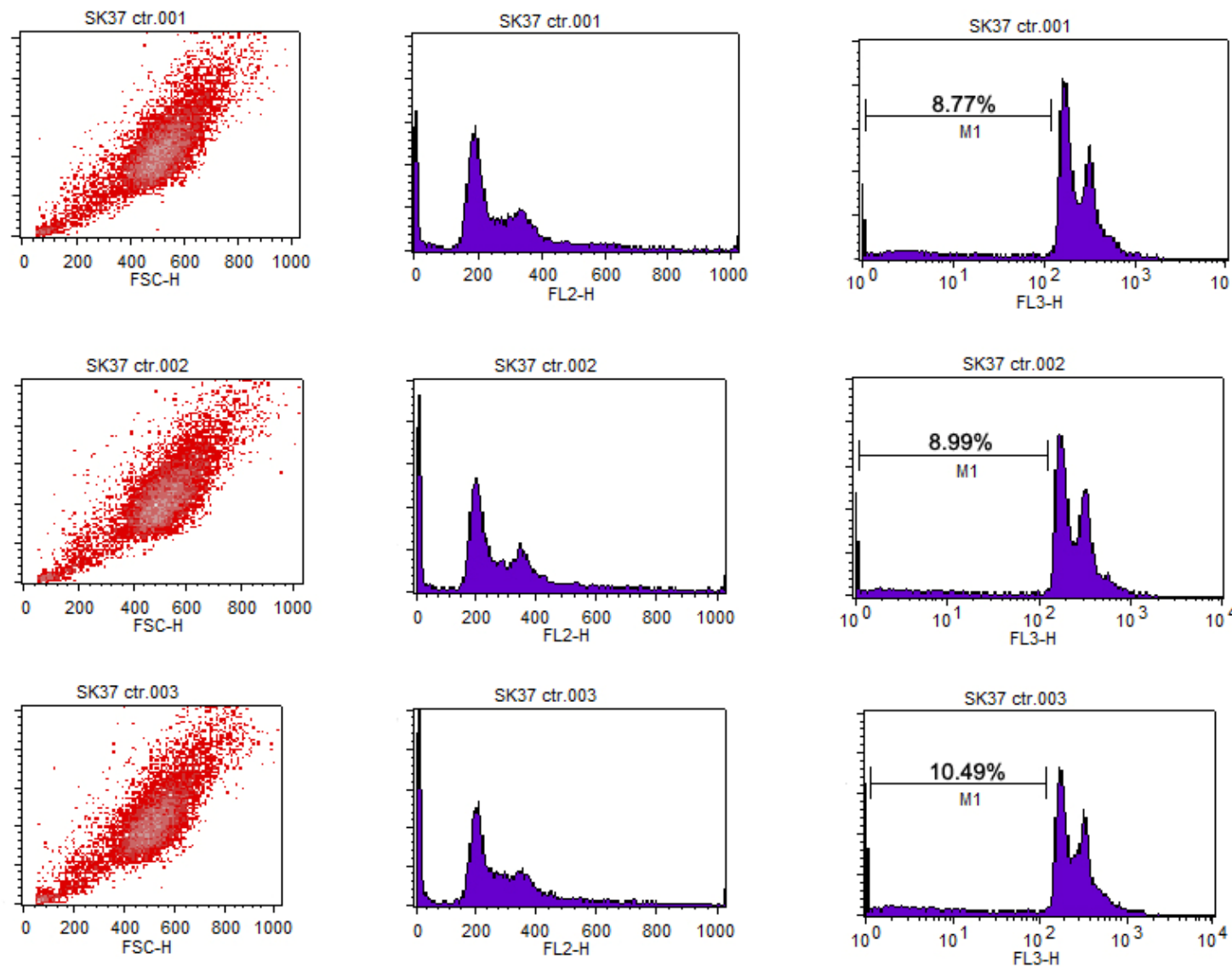

Figura 3. Analise da linhagem SKMel 37 por citometria de fluxo na ausência de tratamento com cisplatina. O número representa a porcentagem de eventos analisados pelo FACS na região M1 (hipodiplóide). 

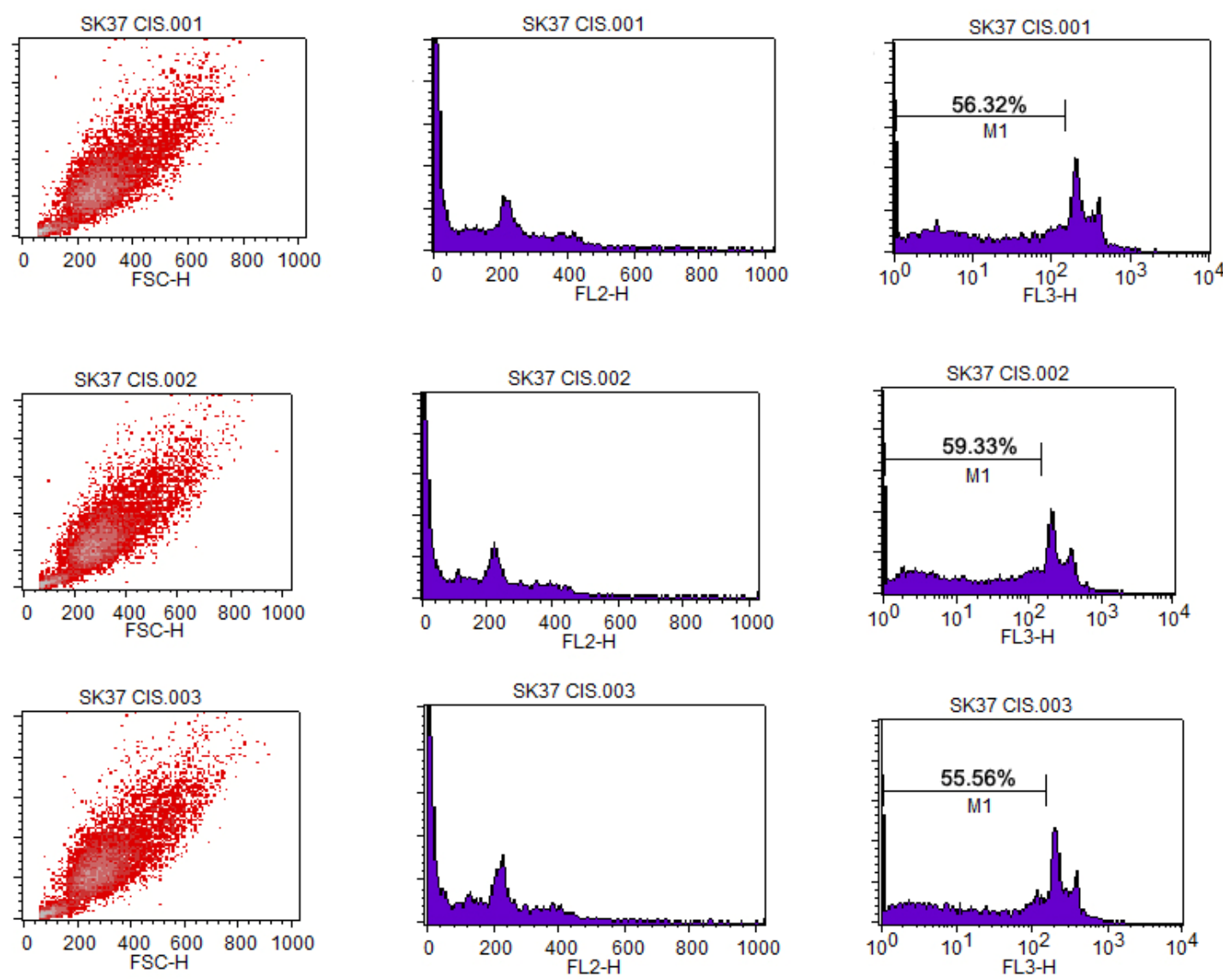

Figura 4. Analise da linhagem SKMel 37 por citometria de fluxo após tratamento com $25 \mu \mathrm{M}$ de cisplatina por 24 horas. O número representa a porcentagem de eventos analisados pelo FACS na região M1 (hipodiplóide). 

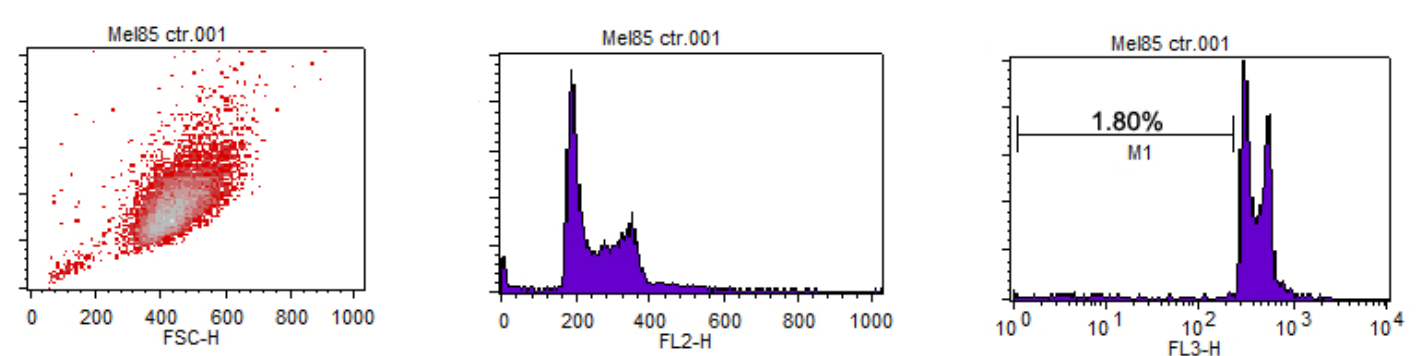

Mel85 ctr.002

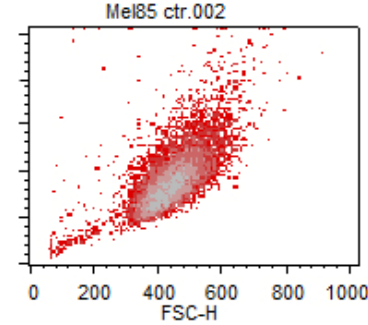

Mel85 ctr.003

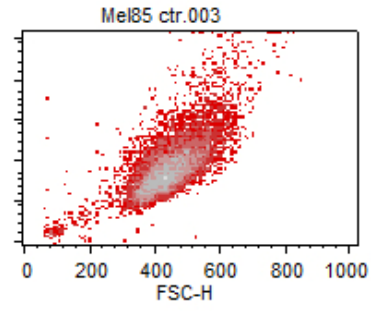

Mel85 ctr.002

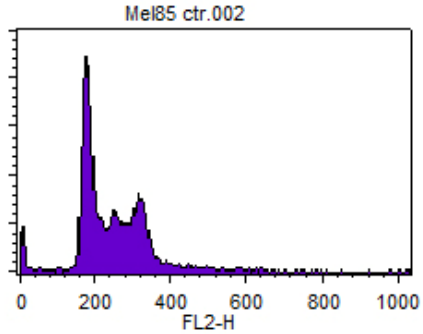

Mel85 ctr.003

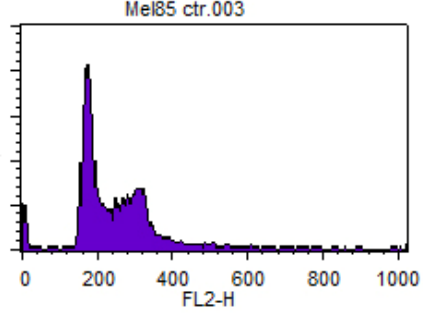

Mel85 ctr.002
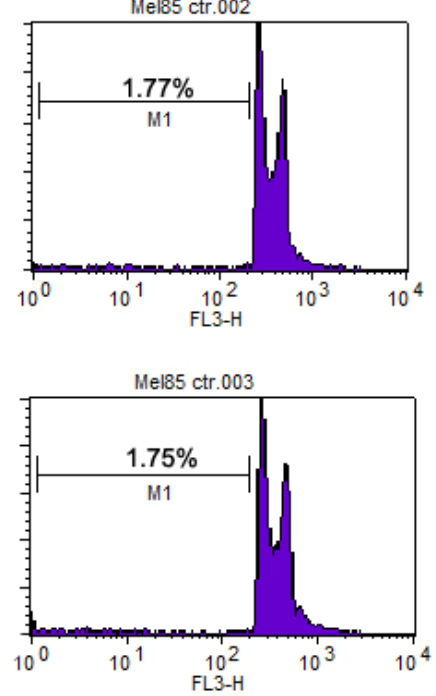

Figura 5. Analise da linhagem Mel 85 por citometria de fluxo na ausência de tratamento com cisplatina. O número representa a porcentagem de eventos analisados pelo FACS na região M1 (hipodiplóide). 

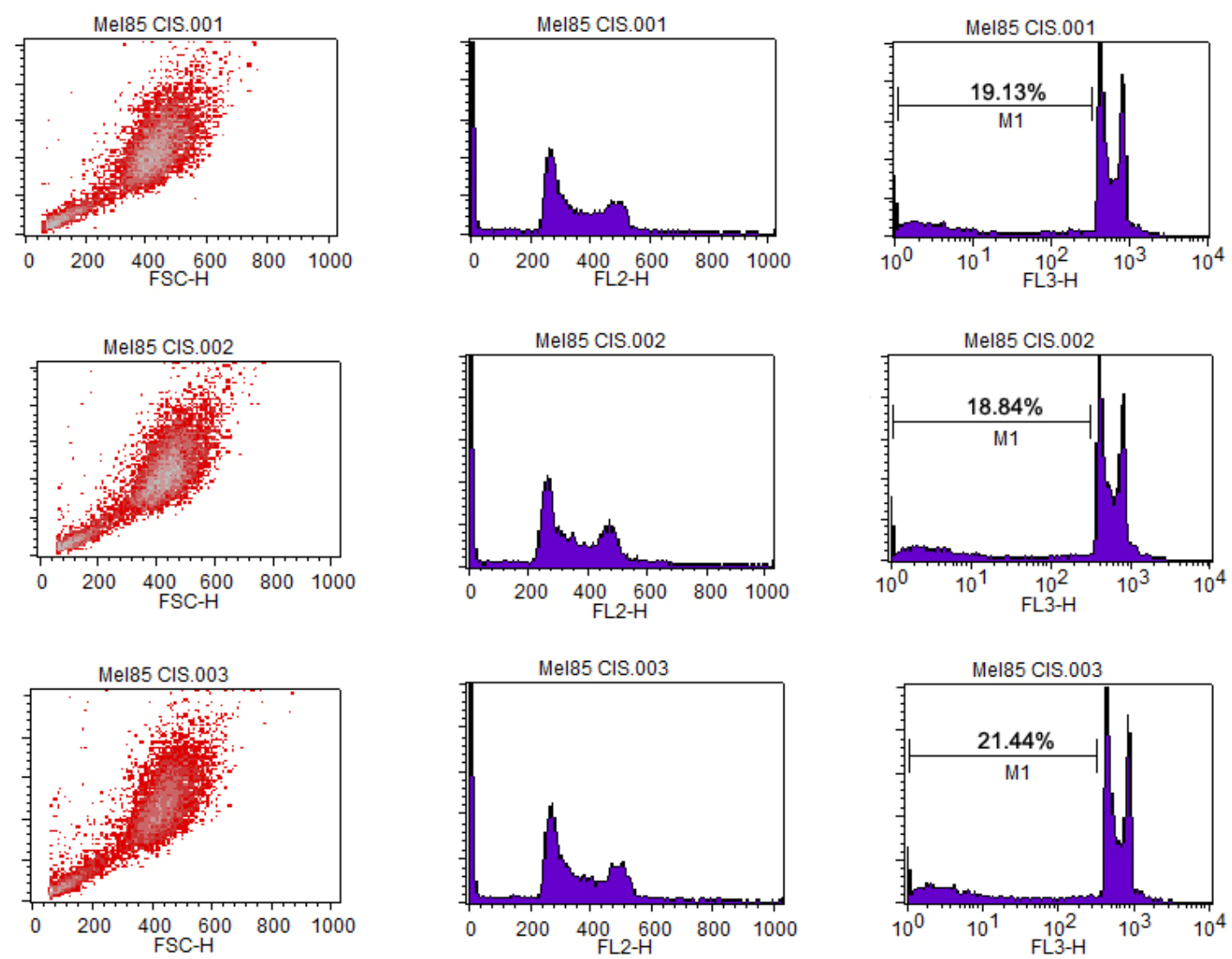

Figura 6. Analise da linhagem Mel 85 por citometria de fluxo após tratamento com $25 \mu \mathrm{M}$ de cisplatina por 24 horas. O número representa a porcentagem de eventos analisados pelo FACS na região M1 (hipodiplóide). 

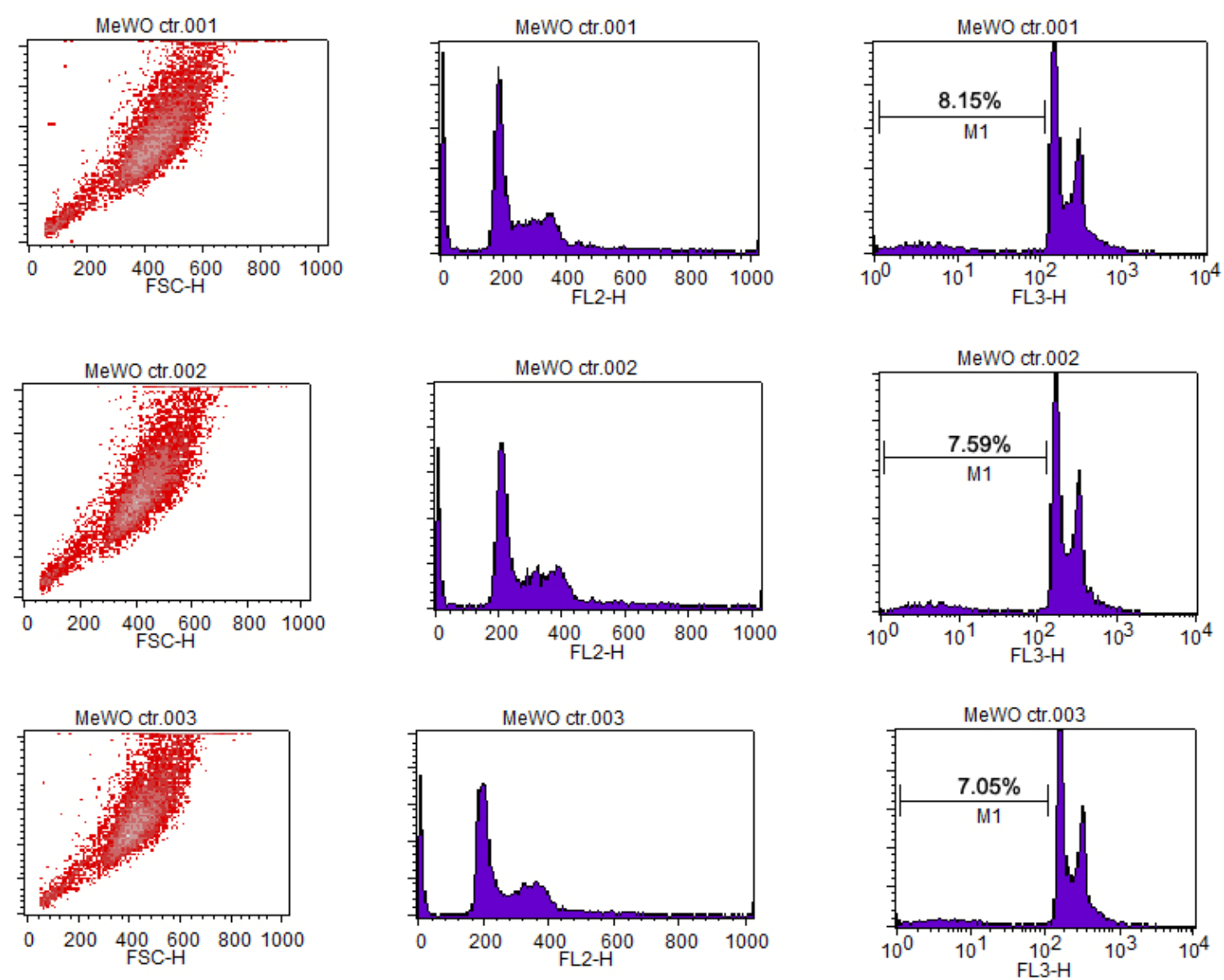

Figura 7. Analise da linhagem MeWO por citometria de fluxo na ausência de tratamento com cisplatina. O número representa a porcentagem de eventos analisados pelo FACS na região M1 (hipodiplóide). 

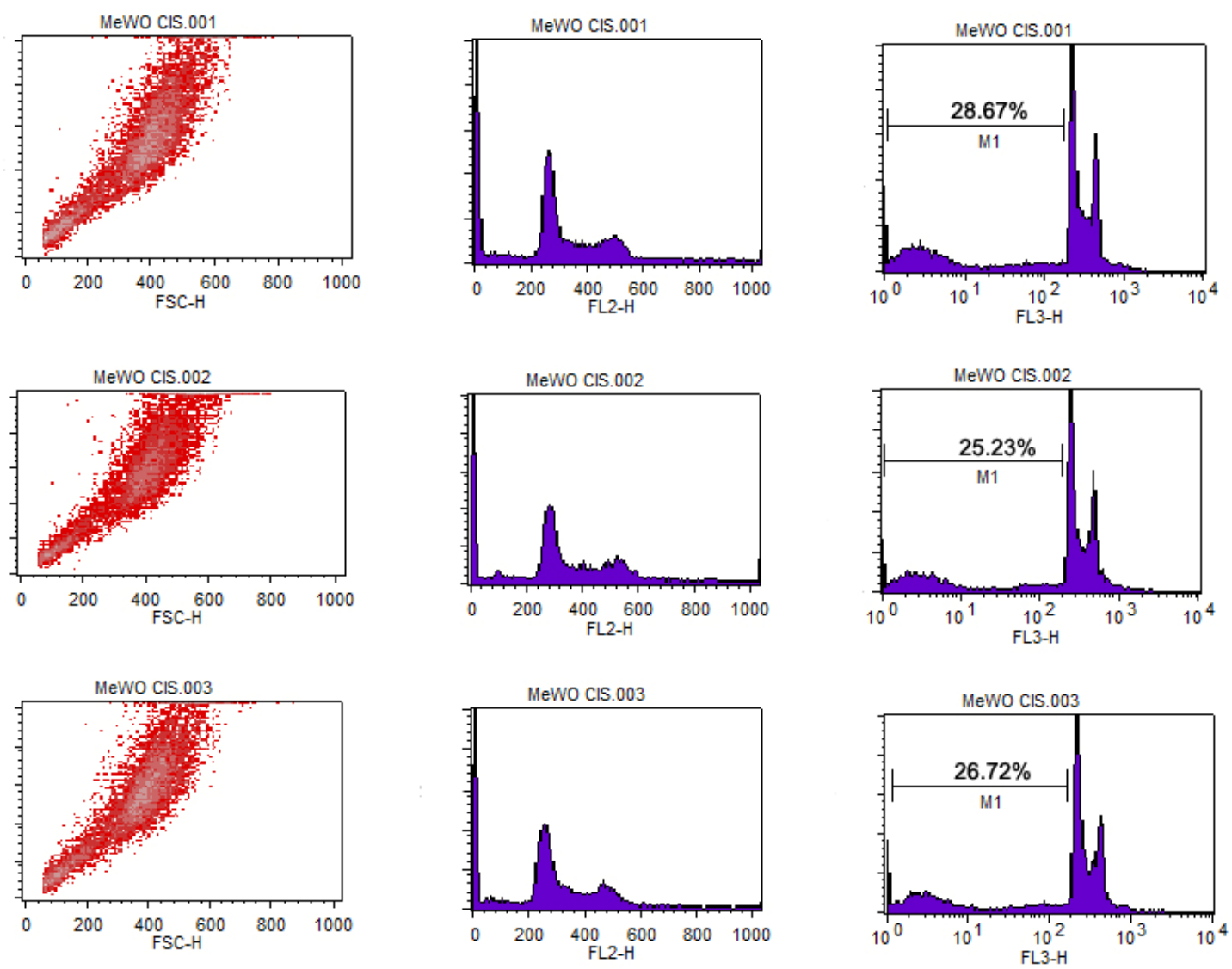

Figura 8. Analise da linhagem MeWO por citometria de fluxo após tratamento com $25 \mu \mathrm{M}$ de cisplatina por 24 horas. O número representa a porcentagem de eventos analisados pelo FACS na região M1 (hipodiplóide). 

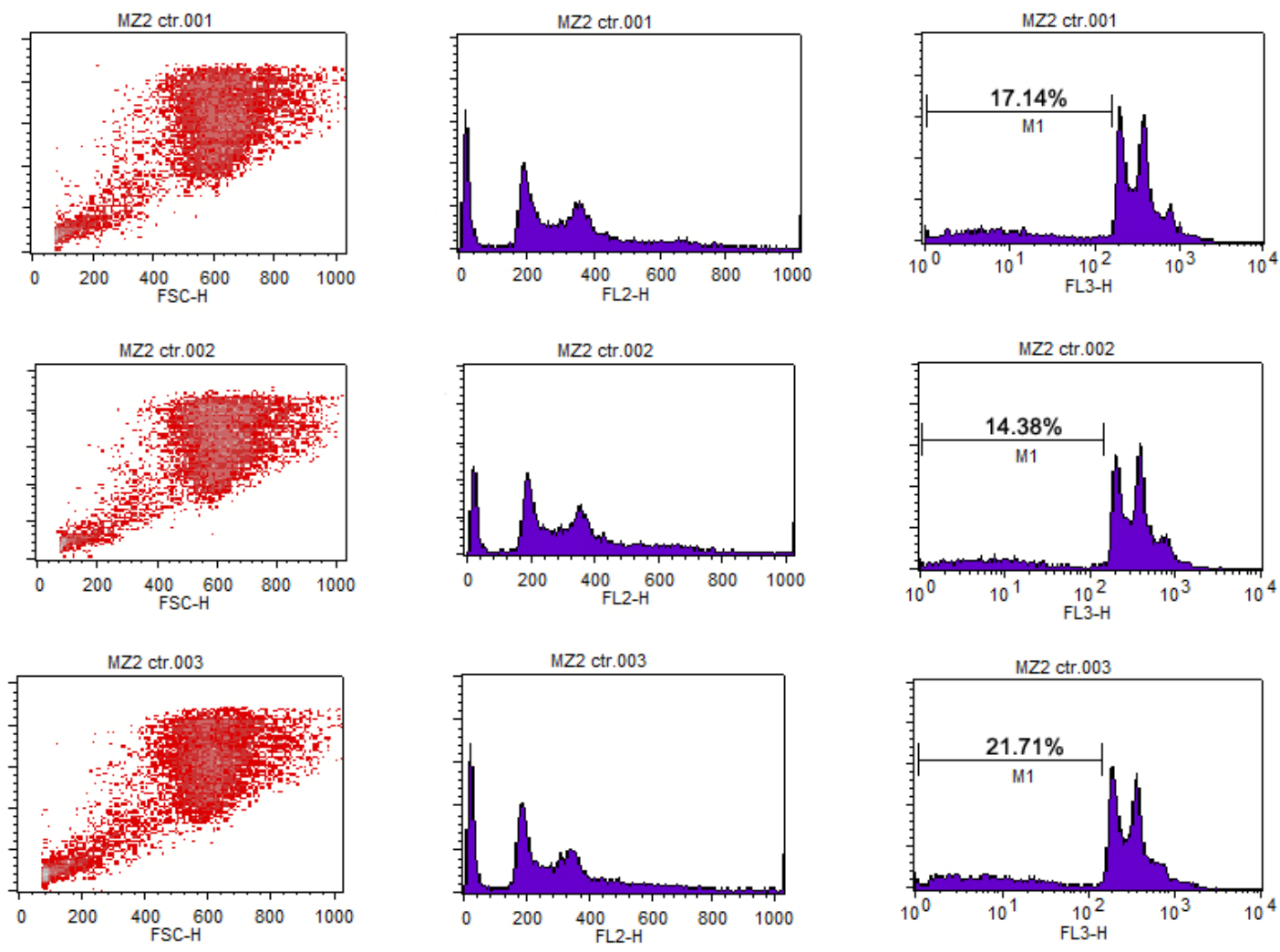

Figura 9. Analise da linhagem MZ2 por citometria de fluxo na ausência de tratamento com cisplatina. O número representa a porcentagem de eventos analisados pelo FACS na região M1 (hipodiplóide). 

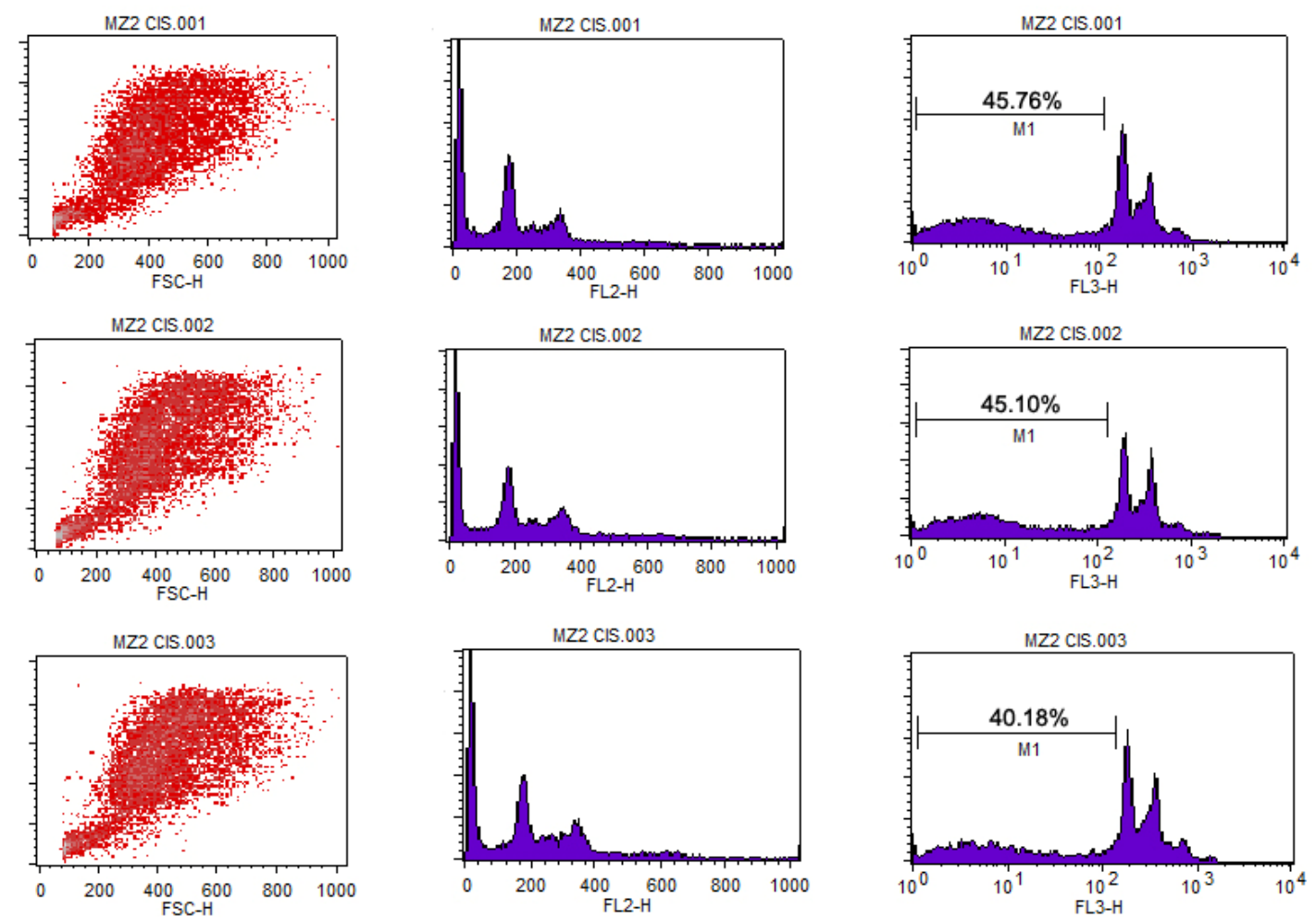

Figura 10. Analise da linhagem MZ2 por citometria de fluxo após tratamento com $25 \mu \mathrm{M}$ de cisplatina por 24 horas. O número representa a porcentagem de eventos analisados pelo FACS na região M1 (hipodiplóide). 
(a)

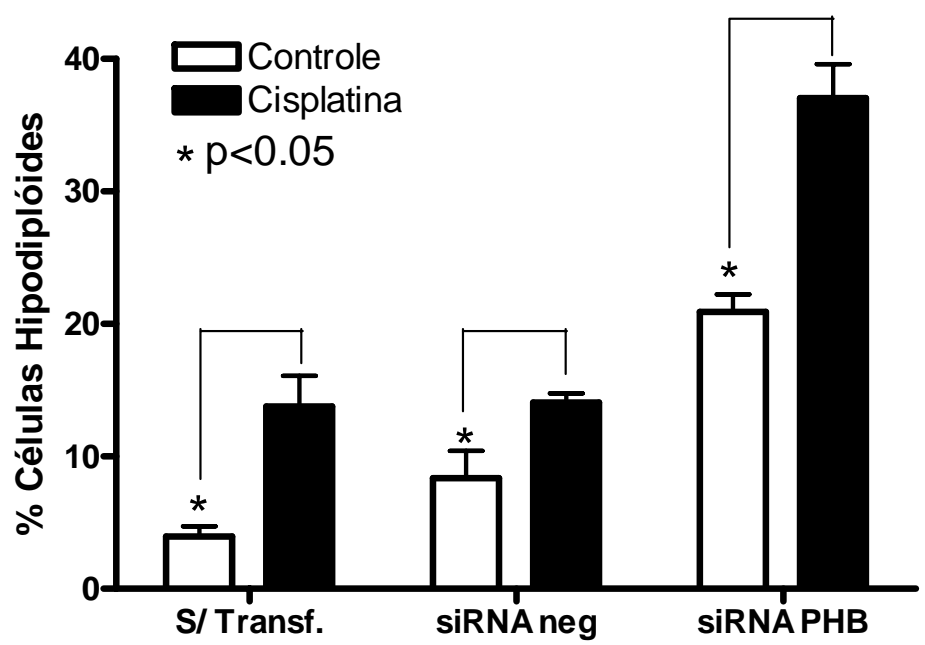

(b)

(c)
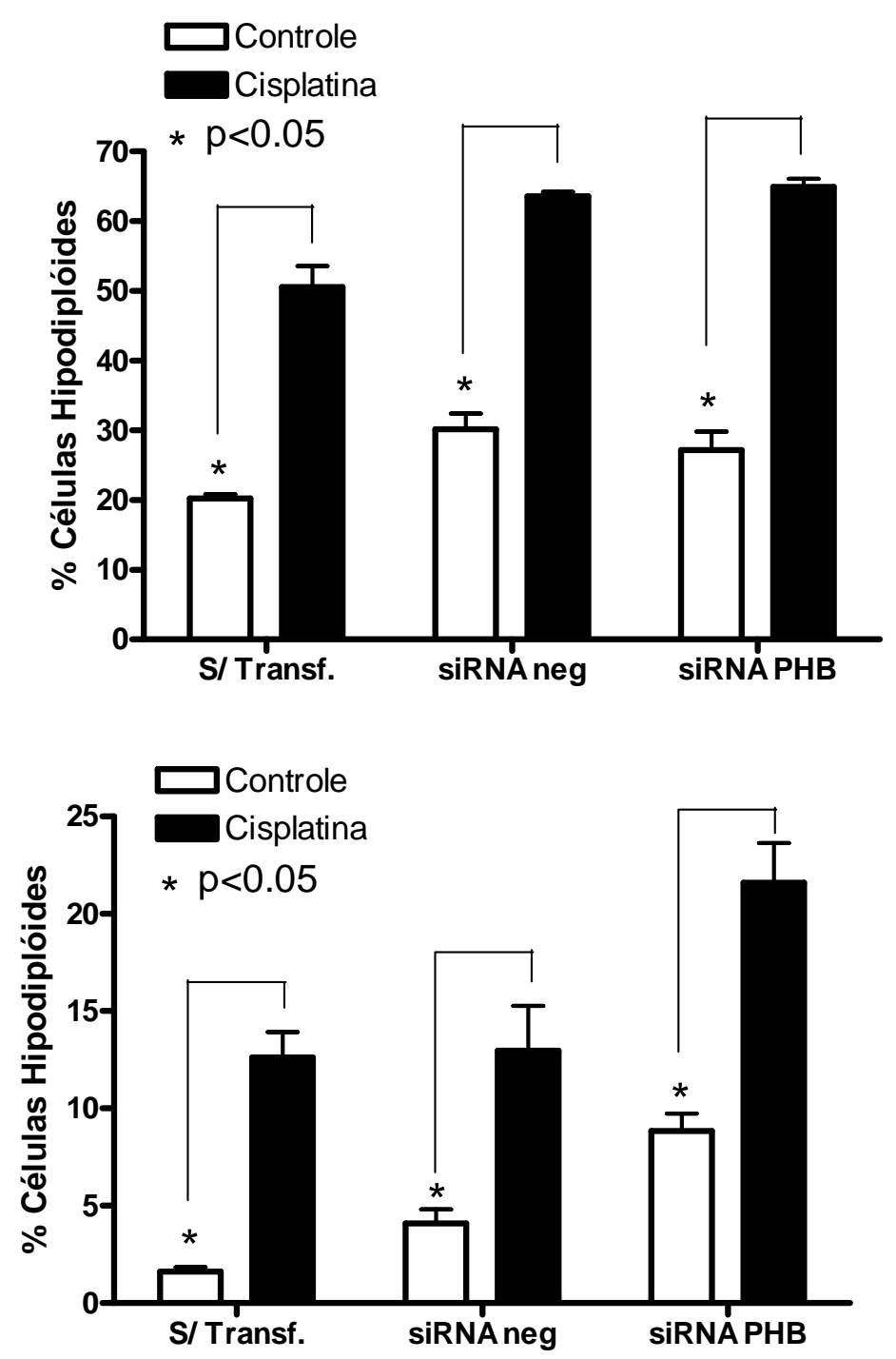

Figura 11. Ensaio de siRNA contra proibitina mostrando o resultado da ação de cisplatina na ausência de transfecção em comparação com a transfecção do siRNA controle e a transfecção do siRNA contra proibitina nas linhagens: (a) LB373Mel; (b) SKMel 37; (c) Mel 85. Ausência de transfecção (S/ Transf.); siRNA controle (siRNA neg); siRNA contra Proibitina (siRNA PHB) 


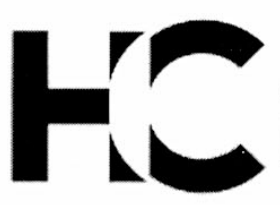

\section{APROVAÇÃO}

A Comissão de Ética para Análise de Proje de Pesquisa - CAPPesq da Diretoria Clínica do Hospital das Clínicas e Faculdade de Medicina da Universidade de São Paulo, em sessão 08.11.06, APROVOU o Protocolo de Pesquisa $\mathbf{n}^{\circ} \mathbf{1 0 5 9 / 0 6}$, intitular "Avaliação do papel de proibitina no desenvolvimento de resistên em melanomas frente a quimioterápicos" apresentado $p$ Departamento de Radiologia.

Cabe ao pesquisador elaborar e apresenta CAPPesq, os relatórios parciais e final sobre a pesquisa (Resolução Conselho Nacional de Saúde n 196, de 10.10.1996, inciso IX. 2, letra "

Pesquisador(a) Responsável: DR. Roger Chammas

Pesquisador (a) Executante: DR. Tharcisio Citrangulo Tortelli Jr

CAPPesq, 08 de novembro de 2006.

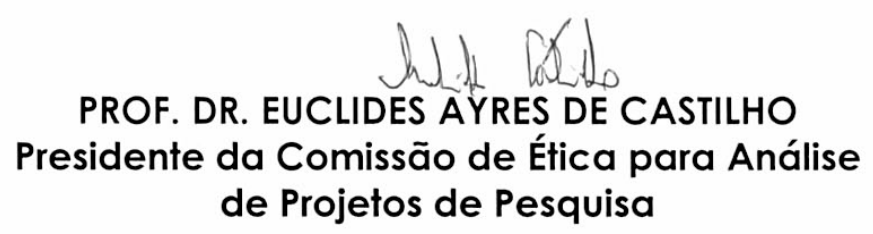
de Projetos de Pesquisa

\footnotetext{
Comissão de Ética para Análise de Projetos de Pesquisa do HCFMUSP e da FMUSP Diretoria Clínica do Hospital das Clínicas da Faculdade de Medicina da Universidade de São Paulo

Rua Ovídio Pires de Campos. 225, $5^{\circ}$ andar - CEP 05403010 - São Paulo - SP Fone: 011 - $30696442 \mathrm{fax}: 011$ - 30696492 - e-mail : cappesq@hcnet.usp.br / secretariacappesq2@hcnet.usp.br 